\title{
30. NORTH ATLANTIC LATE MIOCENE STABLE-ISOTOPE STRATIGRAPHY, BIOSTRATIGRAPHY, AND MAGNETOSTRATIGRAPHY ${ }^{1}$
}

\author{
L. D. Keigwin, Woods Hole Oceanographic Institution \\ M.-P. Aubry, Centre de Paléontologie Stratigraphique et Paléoécologie de l'Université Claude Bernard and \\ Woods Hole Oceanographic Institution \\ and \\ D. V. Kent, Lamont-Doherty Geological Observatory and Department of Geological Sciences of \\ Columbia University ${ }^{2}$
}

\begin{abstract}
Upper Miocene foraminiferal nannofossil ooze and chalk from DSDP Hole 552A in the northeast Atlantic Ocean have been closely sampled for biostratigraphic, paleomagnetic, and stable-isotopic studies. Sampling at 10-cm intervals resulted in an uppermost Miocene isotope stratigraphy with a 1000 - to 3000 -yr. resolution.

Covariance in benthic (Planulina wuellerstorfi) and planktonic (Globigerina bulloides) foraminiferal $\delta^{18} \mathrm{O}$ records is taken as evidence for variability in continental ice volume. Our best estimate is that glacial maxima occurred at $\sim 5.0$ and $\sim 5.5 \mathrm{Ma}$ and lasted no more than 20,000 yrs. These events probably lowered sea level by $60 \mathrm{~m}$ below the latest Miocene average. There is little oxygen-isotope evidence, however, for a prolonged glaciation during the last $2 \mathrm{~m}$.y. of the late Miocene.

High- and low-frequency variability in the $\delta^{13} \mathrm{C}$ record of foraminifers is useful for correlation among North Atlantic DSDP Sites $408,410,522,610$, and 611 , and for correlation with sites in other oceans. Similar $\delta^{13} \mathrm{C}$ changes are seen in $P$. wuellerstorfi and $G$. bulloides, but the amplitude of the signal is always greater in $G$. bulloides. Variability in $\delta^{13} \mathrm{C}$ common to both species probably reflects variability in the $\delta^{13} \mathrm{C}$ of total $\mathrm{CO}_{2}$ in seawater. Major long-term features in the $\delta^{13} \mathrm{C}$ record include a latest Miocene maximum $(P$. wuellerstorf $i=1.5 \%$ ) in paleomagnetic Chron 7 , an abrupt decrease in $\delta^{13} \mathrm{C}$ at $\sim 6.2 \mathrm{Ma}$, and a slight increase at $\sim 5.5 \mathrm{Ma}$. The decrease in $\delta^{13} \mathrm{C}$ at $\sim 6.2 \mathrm{Ma}$, which has been paleomagnetically dated only twice before, occurs in the upper reversed part of Chronozone 6 at Holes 552A and 611C, in excellent agreement with earlier studies. Cycles in $\delta^{13} \mathrm{C}$ with a period of $\sim 10^{4} \mathrm{yrs}$. are interpreted as changes in seawater chemistry, which may have resulted from orbitally induced variability in continental biomass.

Samples of $P$. wuellerstorfi younger than $6 \mathrm{Ma}$ from throughout the North Atlantic have $\delta^{13} \mathrm{C}$ near $1 \%$, on average $\sim 1 \%$ greater than samples of the same age in the Pacific Ocean. Thus, there is no evidence for cessation of North Atlantic Deep Water production resulting from the Messinian "salinity crisis."

Biostratigraphic results indicate continuous sedimentation during the late Miocene after about $\sim 6.5 \mathrm{Ma}$ at Hole 552A. Nannofossil biostratigraphy is complicated by the scarcity of low-latitude marker species, but middle and late Miocene Zones NN7 through NN11 are recognized. A hiatus is present at $\sim 6.5 \mathrm{Ma}$, on the basis of simultaneous first occurrences of Amaurolithus primus, Amaurolithus delicatus, Amaurolithus amplificus, and Scyphosphaera globulata. The frequency and duration of older hiatuses increase downsection in Hole 552A, as suggested by calcareous nannofossil biostratigraphy and magnetostratigraphy.

Paleomagnetic results at Hole 552A indicate a systematic pattern of inclination changes. Chronozone 6 was readily identified because of its characteristic nannoflora (sequential occurrences of species assigned to the genus Amaurolith$u s$ ) and the $\delta^{13} \mathrm{C}$ decrease in foraminifers, but its lower reversed interval is condensed. Only the lower normal interval of Chronozone 5 was recognized at Hole 552A; the upper normal interval and the lowest Gilbert sediment are not recognized, owing to low intensity of magnetization and to coring disturbance. Interpreting magnetic reversals below Chronozone 6 was difficult because of hiatuses, but a lower normally magnetized interval is probably Chronozone 7 .

Correlation between DSDP Hole 552A and other North Atlantic sites is demonstrated using coiling direction changes in the planktonic foraminifer Neogloboquadrina. At most sites this genus changed its coiling preference from dominantly right to dominantly left during the late Miocene. At Hole 552A this event probably occurred about $7 \mathrm{~m} . \mathrm{y}$. ago. At the same time, $P$. wuellerstorfi had maximum $\delta^{13} \mathrm{C}$ values. A similar $\delta^{13} \mathrm{C}$ maximum and coiling change occurred together in Chron 7 at Hole $611 \mathrm{C}$, and at Hole 610E. In sediment younger than $\sim 5.5 \mathrm{Ma}$, the coiling of small Neogloboquadrina species is random, but the larger species $N$. atlantica retains preferential left coiling.
\end{abstract}

\section{INTRODUCTION}

Studies of the late Miocene environment have increased in number since Kennett (1967) first recognized the re-

\footnotetext{
${ }^{1}$ Ruddiman, W. F., Kidd, R. B., Thomas, E., et al., Init. Repts. DSDP, 94: Washington (U.S. Govt. Printing Office).

2 Addresses: (Keigwin) Woods Hole Oceanographic Institution, Woods Hole, MA 02543; (Aubry) Centre de Paléontologie stratigraphique et Paléoécologie de l'Université Claude Bernard, associé au Centre National de la Recherche Scientifique (L.A. No. 11), 27-43 Bd. du 11 Novembre, 69622 Villeurbanne cedex, France, and Woods Hole Oceanographic Institution, Woods Hole, MA 02543; (Kent) Lamont-Doherty Geological Observatory and Department of Geological Sciences of Columbia University, Palisades, NY 10964.
}

gressive nature of the Kapitean Stage in New Zealand and suggested that the regression resulted from Antarctic glaciation. Subsequently published evidence for isolation and desiccation of the Mediterranean (Ryan, Hsü, et al., 1973) led to speculation by many workers about possible relationships between Antarctic glaciation and Mediterranean isolation (e.g., Ryan et al., 1974, and Van Couvering et al., 1976).

Knowledge of late Miocene environmental conditions received a considerable boost from the CENOP (Cenozoic Paleoceanography) project, but its emphasis was mostly on the Pacific and Indian oceans. Only two 
CENOP papers presented stable-isotope results from North Atlantic DSDP sites (Bender and Keigwin, 1979; Matthews et al., 1980), and only a few other workers have produced additional data (Shackleton and Cita, 1979; Vergnaud Grazzini et al., 1978; Blanc and Duplessy, 1982). At first this seems surprising, considering the importance of the North Atlantic to the deep circulation of the rest of the world ocean. The explanation probably is that Hydraulic Piston Coring (HPC) did not begin in the North Atlantic until Leg 80, and a good upper Miocene sequence of pelagic sediment was not recovered until Leg 81. Those efforts were followed by the highly successful Leg 94 .

This chapter examines in detail the stratigraphic record of the first long HPC sequence of upper Miocene sediment taken in the North Atlantic Ocean (DSDP Hole 552A), and compares this record with that of other sites in the region (Fig. 1, Table 1). Our detailed sampling at Hole 552A for nannofossil stratigraphy and magnetostratigraphy allows recognition of the lower parts of Chronozones 5, 6, and 7 (partim). The sample spacing for stable isotopes $(10 \mathrm{~cm}$ over $40 \mathrm{~m}$ of uppermost Miocene sediment, corresponding to 1,000 - to 3,000-yr. intervals) resulted in the highest-resolution record to date of environmental changes in the latest Miocene.

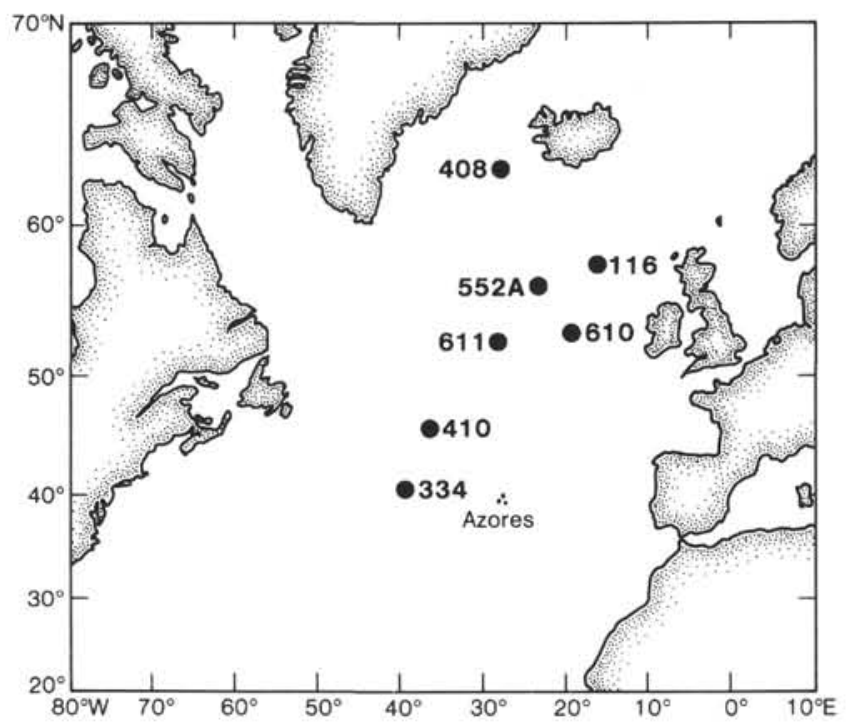

Figure 1. Locations of Deep Sea Drilling Project sites discussed in this chapter.

Table 1. Site Locations.

\begin{tabular}{lccc}
\hline & $\begin{array}{c}\text { Water } \\
\text { depth } \\
(\mathrm{m})\end{array}$ & \multicolumn{1}{c}{ Latitude } & \multicolumn{1}{c}{ Longitude } \\
\hline Site 334 & 2619 & $37^{\circ} 02.13^{\prime} \mathrm{N}$ & $34^{\circ} 24.87^{\prime} \mathrm{W}$ \\
Site 408 & 1624 & $63^{\circ} 22.63^{\prime} \mathrm{N}$ & $28^{\circ} 54.71^{\prime} \mathrm{W}$ \\
Site 410 & 2975 & $45^{\circ} 30.51^{\prime} \mathrm{N}$ & $29^{\circ} 18.56^{\prime} \mathrm{W}$ \\
Hole 552A & 2301 & $56^{\circ} 02.56^{\prime} \mathrm{N}$ & $23^{\circ} 13.88^{\prime} \mathrm{W}$ \\
Hole 610E & 2445 & $53^{\circ} 13.467^{\prime} \mathrm{N}$ & $18^{\circ} 53.690^{\prime} \mathrm{W}$ \\
Hole 611C & 3230 & $52^{\circ} 50.15^{\prime} \mathrm{N}$ & $30^{\circ} 19.10^{\prime} \mathrm{W}$ \\
\hline
\end{tabular}

\section{METHODS}

\section{Paleomagnetics}

Samples for paleomagnetic analysis were taken approximately every $30 \mathrm{~cm}$, avoiding sediment that showed signs of coring disturbance. The natural remanent magnetization (NRM) of each sample was measured on a 2-axis cryogenic magnetometer, both before and after alternating-field (AF) demagnetization at 10 to $30 \mathrm{mT}$; progressive $\mathrm{AF}$ demagnetization of pilot samples showed that $10 \mathrm{mT}$ was usually sufficient to remove a small, spurious, low-stability component and to uncover a stable characteristic magnetization.

\section{Stable Isotopes}

For Sites 334, 408, and $410,10-\mathrm{cm}^{3}$ samples were taken at various intervals, depending on core recovery. Some samples from Sites 408 and 410 were provided by R. Z. Poore, and have also been reported on earlier (Poore, 1979, 1981). This sample set was supplemented by additional sampling at those sites as well as Site 334 . Hole 610E was sampled at $50-\mathrm{cm}$ intervals, Site $611 \mathrm{C}$ at $1-\mathrm{m}$ intervals, and Hole $552 \mathrm{~A}$ was first sampled at relatively large intervals (Keigwin, 1984) and later at $10-\mathrm{cm}$ intervals. Samples provided by Poore were disaggregated both with and without $\mathrm{H}_{2} \mathrm{O}_{2}$. There appears to be no obvious artifact in the results attributable to $\mathrm{H}_{2} \mathrm{O}_{2}$ treatment; this is consistent with the results of Ganssen (1981). Samples taken for this project were chosen so as to avoid contamination from coring disturbances along the core liner and from down the borehole (sometimes seen in the top few tens of centimeters of each core).

Stable-isotope analyses followed the procedures outlined elsewhere (Keigwin, 1984). Throughout the course of this study, hundreds of analyses of NBS-20 (Solnhofen Limestone) have shown it to be a suitable standard. For example, from March 1983 to February 1984, 81 analyses resulted in $\delta^{18} \mathrm{O}=-5.29 \pm 0.08 \% 0, \delta^{13} \mathrm{C}=-1.87 \pm 0.08 \%$ (with respect to laboratory reference gas). Results were converted to $\mathrm{PDB}$, using the Craig corrections, taking NBS-20 $\delta^{18} \mathrm{O}=-4.18 \%$ and $\delta^{13} \mathrm{C}=-1.06 \%$.

\section{Biostratigraphy}

Samples taken for stable-isotope study were also examined for foraminiferal biostratigraphy. Subsamples from within the $10-\mathrm{cm}^{3} \mathrm{sam}-$ ples were used for making nannofossil slides. Some of these samples, however, showed nannofossil evidence of downhole or laboratory contamination, so an entirely new set of smear slides was prepared from all samples taken for paleomagnetic analysis.

\section{BIOSTRATIGRAPHY OF HOLE 552A}

No high-latitude biostratigraphic zonation is available for use in the North Atlantic region, so our results reflect laborious searching for low-latitude marker species. The upper 12 cores of Hole 552A have already proved useful for detailed stratigraphic study (Shackleton, Backman, et al., 1984). Magnetostratigraphic and biostratigraphic datum levels in Hole 552A are summarized in an age-depth plot (Fig. 2). Cores 13 and 14 (59-67 m sub-bottom), parts of Cores 15 and $16(67-77 \mathrm{~m})$, and all of Cores 17-22 (77-104 m) are badly disturbed, even though taken with the HPC (Roberts, Schnitker, et al., 1984). Cores from deeper than $104 \mathrm{~m}$ have only a minor degree of coring disturbance at the top, and appear suitable for detailed study. Laminae are evident in the foraminiferal nannofossil ooze and chalk down through Core 24 (to $138.5 \mathrm{~m}$ ). Recovery in Hole 552A was $99.7 \%$.

\section{Calcareous Nannofossils}

The highest-resolution biostratigraphy at Hole 552A comes from our study of calcareous nannofossils (Fig. 3). Calcareous nannofossils constitute a prime tool for biostratigraphic subdivision of the upper Miocene, where 


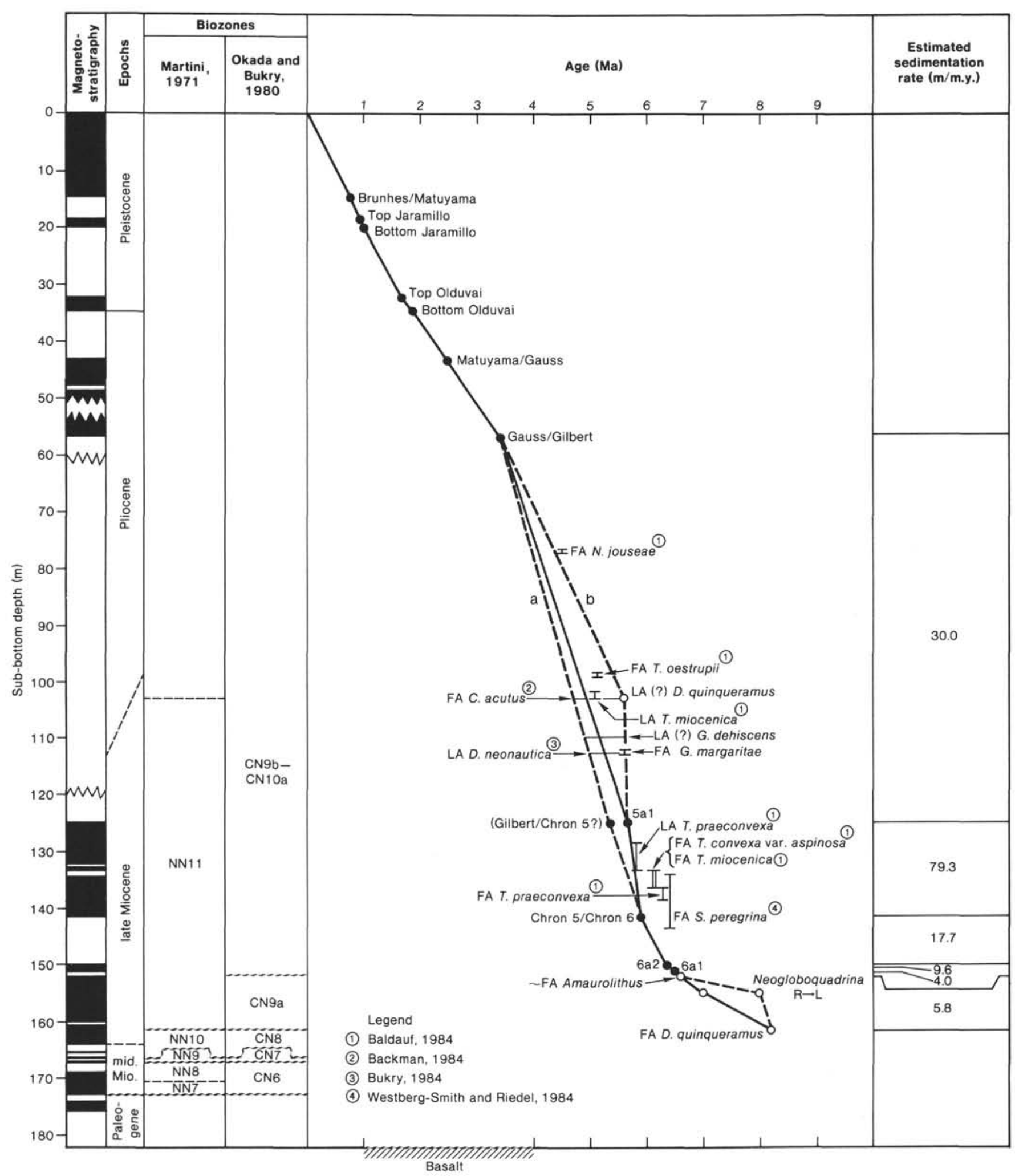

Figure 2. Age-depth plot of paleomagnetic and biostratigraphic results for Hole 552A. Paleomagnetic reversal boundaries (solid points) above $60 \mathrm{~m}$ sub-bottom are from Shackleton, Backman, et al. (1984) and ones lower in the section are from this study. Open data points mark faunal and floral events which are not well dated or which may not represent the actual first or last appearances at this site. Vertical lines represent the depth ranges over which biostratigraphic datum levels were found and horizontal lines reflect the possible range of ages for other biostratigraphic events. Our preferred time scale for events at Hole 552A is the solid line. Alternative, but less satisfactory, interpretations are shown by the dashed lines ( $\mathrm{a}$ and $\mathrm{b}$ ) and are discussed in the text. Sedimentation rates were calculated using the ages of magnetic reversals, except for the interval below $152 \mathrm{~m}$, where nannofossil stratigraphy was used. 


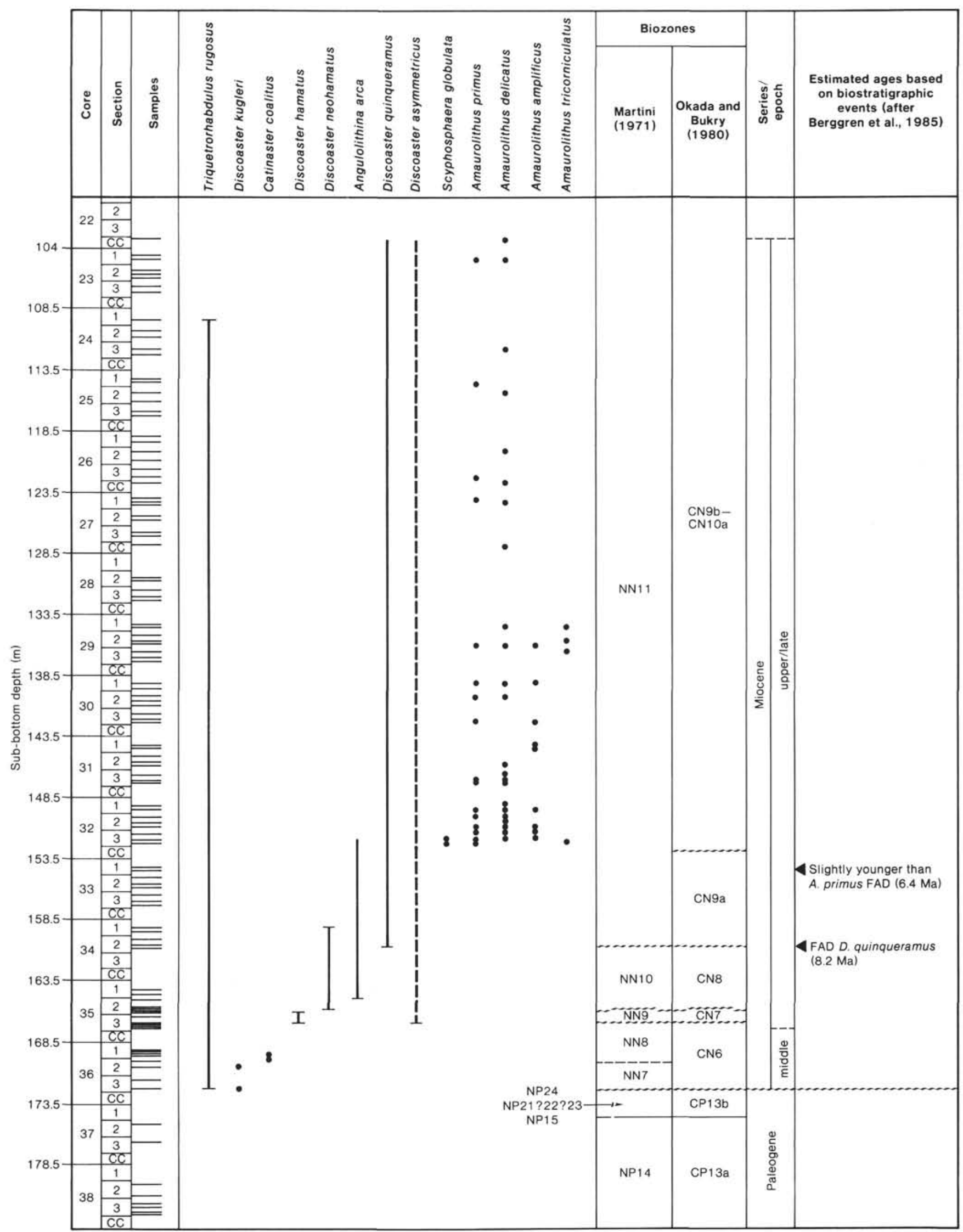

Figure 3. Range of calcareous nannofossil species at Hole 552A. Determination of Paleogene zones after Backman (1984). Section 3 of Core 34 was not sampled, because of coring disturbance. 
they provide a number of sequential datum levels. These levels have been tied to the magnetostratigraphic record (Berggren et al., in press), and the first occurrence of Amaurolithus primus has been tied to the carbon isotopic record (Haq et al., 1980). Thus, precise calcareous nannofossil biostratigraphic control is necessary to interpret with confidence our upper Miocene isotopic and magnetostratigraphic results (discussed later). Samples were examined at about $30-\mathrm{cm}$ intervals from 104 to $158.5 \mathrm{~m}$ sub-bottom (Cores 23-33), to supplement the earlier observations of Backman (1984). In addition, samples were also examined from Cores 34 through 38 in an attempt to interpret the magnetostratigraphic record of this interval.

Discussion of the biostratigraphy of Cores 37 and 38 can be found in the work of Backman (1984), who pointed out that a major Paleogene/Neogene unconformity occurs at $172.9 \mathrm{~m}$ (Section 36-3). Calcareous nannofossil assemblages are of low diversity and are poorly to moderately preserved in the middle and upper Miocene of Hole 552A. Discoasters in particular may have broken tips or may be overgrown, which hampers the taxonomic determination of many specimens. Care was taken to avoid taxonomic confusion. For example, in poorly preserved sediment, Discoaster pentaradiatus with broken tips may be confused with $D$. quinqueramus, but the peculiar interference figure of $D$. pentaradiatus in cross-polarized light helps to distinguish between the two species.

Coccolithus pelagicus and Reticulofenestra pseudoumbilica alternately dominate the assemblages in which $\mathrm{Cal}$ cidiscus macintyrei, Helicosphaera carteri, and Sphenolithus neoabies are relatively common. Representatives of the genus Scyphosphaera are very common at some levels. Ceratoliths do occur, but most often they are exceedingly rare, and finding them required a long search.

Owing to the scarcity of some marker species and to the generally poor preservation, there is some risk in delineating datum levels (Figs. 2 and 3). The uncertainty with which the datum levels were identified is offset somewhat, however, by close sampling. The lowermost middle Miocene sediments in Core 36 are assigned to Zones NN7 and NN8. Discoaster kugleri and Triquetrorhabdulus rugosus occur at $172.62 \mathrm{~m}(36-3,112-114 \mathrm{~cm})$. Rare Sphenolithus heteromorphus occurs at levels between 169.9 and $171.7 \mathrm{~m}(36-3,25-27 \mathrm{~cm} ; 36-2,25-27$ $\mathrm{cm}$; 36-1, 144-146 cm), suggesting reworking of this older species (NN4, NN5). Discoaster hamatus occurs from $167.25 \mathrm{~m}(35-3,75-77 \mathrm{~cm})$ to $166.44 \mathrm{~m}(35-2,144-146$ $\mathrm{cm}$ ), indicating Zone NN9. Discoaster neohamatus first occurs at $166.25 \mathrm{~m}(35-2,125-127 \mathrm{~cm})$. The interval between 164.25 and $166.25 \mathrm{~m}(35-1,74 \mathrm{~cm}$ to $35-2,125$ $\mathrm{cm}$ ) is assigned to Zone NN10. In this interval, $D$. neohamatus is common, and forms intermediate between $D$. bellus and $D$. quinqueramus are present. The lowest occurrence of rare but typical $D$. quinqueramus is at $161.25 \mathrm{~m}(34-2,125 \mathrm{~cm})$. Thus, the base of Zone NN11 is drawn between 161.25 and $164.25 \mathrm{~m}(34-2,125 \mathrm{~cm}$ to $35-1,74 \mathrm{~cm}$ ). Discoaster quinqueramus becomes "common" above $155.75 \mathrm{~m}(33-2,75 \mathrm{~cm})$, and occurs continuously up to $120.30 \mathrm{~m}(26-2,30 \mathrm{~cm})$. Above $120.30 \mathrm{~m}$, discoasters are very rare and preservation decreases even further; and $D$. quinqueramus was not identified at all levels. Specimens assignable to this species occur sporadically, however, and were present in samples at 104.45 and $103.10 \mathrm{~m}(23-1,45 \mathrm{~cm}$ and $22, \mathrm{CC}[10 \mathrm{~cm}])$. The lowest occurrence of non-birefringent ceratoliths is at $152.25 \mathrm{~m}(32-3,76-78 \mathrm{~cm})$, where Amaurolithus primus and Scyphosphaera globulata were found. The simultaneous appearance of these two species, followed immediately upsection by the occurrence of $A$. delicatus and A. amplificus, suggests an unconformity. In continuous upper Miocene sections, species of the genus Amaurolithus appear sequentially (Berggren et al., in press). Also, the first appearance datum (FAD) of $S$. globulata shortly follows that of $A$. primus (Bukry, 1973). The last occurrence of Triquetrorhabdulus rugosus was found at $109.55 \mathrm{~m}$ (24-1, 105-106 cm). Despite patient search, Ceratolithus acutus was not found, and its citation in Sample 22,CC (Backman, 1984) is not confirmed.

The last appearance datum (LAD) of $D$. quinquera$m u s$ has not yet been satisfactorily established with respect to other biostratigraphic events and magnetostratigraphy. Berggren et al. (in press) suggest an age of $5.6 \mathrm{Ma}$ for this event. The highest occurrence of $D$. quinqueramus at $103.10 \mathrm{~m}$ (Sample 22,CC) is probably not its LAD, because our sampling ended at that level. The reported occurrence of the early Pliocene marker species Ceratolithus acutus within the same core-catcher sample (Backman, 1984) suggests that the Miocene/Pliocene boundary is close to $103 \mathrm{~m}$ sub-bottom.

\section{Planktonic Foraminifers}

Planktonic foraminiferal stratigraphy was initially reported by Huddlestun (1984), and has been examined in greater detail for this report. We find that the only notable late Miocene first or last appearance is the FAD of Globorotalia margaritae. This species first occurs in samples at 112.11 and $112.20 \mathrm{~m}$ and then again in samples between 109.30 and $110.20 \mathrm{~m}$. Curiously, the uppermost of these samples has a few specimens of the only Globoquadrina dehiscens observed at this site. These observations contrast with Huddlestun's (1984) results, which show the FAD of G. margaritae at about $153 \mathrm{~m}$. G. margaritae is usually recorded at or slightly above a level thought to mark the Gilbert/Chronozone 5 boundary (Berggren et al., in press), although in the eastern equatorial Pacific it was found to occur first within Chronozone 5 (Saito et al., 1975). Specimens comparable to those from $112.20 \mathrm{~m}$ in Hole $552 \mathrm{~A}$ were found at Site 502 , in the western Caribbean, just preceding the first appearance of Globorotalia tumida, which was used to mark the Miocene/Pliocene boundary (Keigwin, 1982). Since the last occurrence of $G$. dehiscens is also used to mark the Miocene/Pliocene boundary (Saito et al., 1975; Berggren, 1977), the limited planktonic foraminiferal evidence at Hole 552A suggests that this boundary occurs at about $110 \mathrm{~m}$.

At lower-latitude sites, changes in the coiling direction of Neogloboquadrina acostaensis have been used as stratigraphic markers, and are important for estimating ages of events in the Mediterranean region (Saito et al., 
1975; Cita and Ryan, 1979). The coiling direction in Neogloboquadrina pachyderma in the upper Quaternary is related to sea surface temperature (Bandy, 1960, e.g.), and coiling in Neogloboquadrina atlantica appears to have stratigraphic significance (Berggren, 1972). This chapter and that by Weaver (this volume) establish that the coiling shift in $N$. atlantica, previously thought to mark the Miocene/Pliocene boundary (Berggren, 1972), occurred within the late Miocene.

Considering the importance of coiling direction in the Neogloboquadrina plexus, it was investigated for stratigraphic significance at sites of this study (Table 2). Sam-

Table 2. Neogloboquadrina coiling direction.

\begin{tabular}{ccccc}
\hline $\begin{array}{c}\text { Sub-bottom } \\
\text { depth } \\
(\mathrm{m})\end{array}$ & $\begin{array}{c}\text { Total } \\
\text { number in } \\
180-300 \mu \mathrm{m} \\
\text { split }\end{array}$ & $\begin{array}{c}\text { Left } \\
(\%)\end{array}$ & $\begin{array}{c}\text { Total } \\
\text { number in } \\
>300 \mu \mathrm{m} \\
\text { split }\end{array}$ & $\begin{array}{c}\text { Left } \\
(\%)\end{array}$ \\
\hline Site 410 & & & & \\
& & & \\
149.00 & 294 & 11 & \\
170.70 & 198 & 97 & \\
175.10 & 188 & 95 & \\
188.50 & 131 & 95 & \\
198.30 & 112 & 91 & \\
219.26 & 127 & 95 & \\
233.42 & 113 & 98 & \\
238.00 & 139 & 89 & \\
239.40 & 140 & 93 & \\
246.21 & 62 & 32 & \\
257.00 & 142 & 55 & \\
275.60 & 205 & 11 & \\
279.00 & 95 & 25 &
\end{tabular}

Hole 610E

$\begin{array}{rrrrr}280.30 & 165 & 93 & 2 & 100 \\ 283.00 & 102 & 98 & & \\ 289.90 & 110 & 97 & 4 & 100 \\ 286.80 & 124 & 98 & 16 & 100 \\ 289.40 & 159 & 86 & & \\ 292.10 & 85 & 50 & & \\ 293.90 & 92 & 47 & & \\ 296.88 & 153 & 44 & & \\ 299.50 & 148 & 20 & 8 & 50 \\ 303.00 & 206 & 34 & 216 & 10 \\ 305.00 & 202 & 36 & 59 & 3 \\ 307.00 & 107 & 11 & 112 & 6\end{array}$

Hole 552A

$\begin{array}{lllll}105.90 & 302 & 47 & & \\ 107.52 & 160 & 85 & & \\ 108.70 & 359 & 91 & & \\ 109.30 & 355 & 49 & & \\ 110.20 & 531 & 35 & & \\ 111.70 & 465 & 45 & 211 & 100 \\ 112.60 & 162 & 28 & & \\ 113.70 & 245 & 69 & 162 & 96 \\ 114.40 & 129 & 65 & & \\ 114.68 & 254 & 39 & & \\ 114.98 & 195 & 26 & 42 & 98 \\ 116.60 & 103 & 38 & 19 & 95 \\ 117.80 & 217 & 57 & 31 & 97 \\ 118.10 & 353 & 59 & & \\ 118.70 & 164 & 55 & 82 & 98 \\ 119.03 & 185 & 97 & & \\ 119.33 & 144 & 96 & & \\ 119.92 & 149 & 88 & 20 & 100 \\ 121.71 & 141 & 43 & & \\ 123.02 & 163 & 90 & 101 & 96 \\ 124.51 & 228 & 95 & & \\ 126.22 & 253 & 96 & & \\ 127.54 & 165 & 97 & & \\ 129.12 & 162 & 91 & 146 & 100\end{array}$

Table 2 (continued).

\begin{tabular}{ccccr}
\hline $\begin{array}{c}\text { Sub-bottom } \\
\text { depth } \\
\text { (m) }\end{array}$ & $\begin{array}{c}\text { Total } \\
\text { number in } \\
180-300 \mu \mathrm{m} \\
\text { split }\end{array}$ & $\begin{array}{c}\text { Left } \\
(\%)\end{array}$ & $\begin{array}{c}\text { Total } \\
\text { number in } \\
>300 \mu \mathrm{m} \\
\text { split }\end{array}$ & $\begin{array}{c}\text { Left } \\
(\%)\end{array}$ \\
\hline Hole 552A (Cont.) & & & & \\
131.02 & 259 & 78 & 26 & 88 \\
132.03 & 1458 & 82 & & \\
132.92 & 370 & 22 & & \\
133.04 & 528 & 33 & & \\
133.23 & 278 & 79 & & \\
135.00 & 261 & 95 & & \\
137.94 & 147 & 92 & 95 & 99 \\
147.10 & 227 & 95 & 31 & 97 \\
149.00 & 165 & 95 & 93 & 98 \\
151.60 & 151 & 95 & 1 & 100 \\
154.60 & 137 & 94 & 20 & 95 \\
155.10 & 156 & 90 & 5 & 80 \\
156.12 & 98 & 21 & 2 & 0 \\
157.62 & 89 & 17 & 17 & 12 \\
162.10 & 166 & 14 & 176 & 5 \\
167.62 & 202 & 8 & 79 & 9
\end{tabular}

Hole 611C

$\begin{array}{lrr}319.8 & 27 & 100 \\ 331.90 & 196 & 96 \\ 339.22 & 8 & 100 \\ 371.73 & 42 & 98 \\ 373.84 & 101 & 89 \\ 380.90 & 116 & 97 \\ 382.90 & 45 & 98 \\ 385.90 & 57 & 96 \\ 387.75 & 7 & 29 \\ 389.54 & 9 & 56 \\ 390.54 & 42 & 5 \\ 391.50 & 37 & 14 \\ 392.50 & 48 & 27 \\ 394.50 & 31 & 10\end{array}$

ples were split and the coiling direction of all Neogloboquadrina was noted in the size fractions 180 to $300 \mu \mathrm{m}$ and greater than $300 \mu \mathrm{m}$. Separation according to size is a convenient, but only approximate, way of distinguishing between the larger $N$. atlantica and the smaller $N$. acostaensis and $N$. pachyderma, since considerable variability occurs within the Neogloboquadrina plexus.

Both large and small Neogloboquadrina change coiling direction from dominantly right to left at about $156 \mathrm{~m}$ in Hole 552A (Table 2). This indicates either a common environmental control or a common genetic control for the species involved. Coiling preference in the larger group, mostly $N$. atlantica, remains dominantly left throughout the section, but the smaller specimens exhibit two spikes of right coiling followed by a random pattern above about $119 \mathrm{~m}$. Whatever controlled Neogloboquadrina coiling no longer acted on $N$. atlantica at the time corresponding to that level. Peaks in abundance of the smaller, left-coiling form $N$. pachyderma may have been associated with cooler surface waters, but data from the southwest Pacific suggest that this association did not develop until late in Pliocene time (Kennett and Vella, 1975). In the equatorial Pacific, the rightto left-coiling change in $N$. acostaensis occurs just below the Chronozone 5/Chronozone 6 boundary (Saito et al., 1975), whereas at Hole 552A it occurs in sediment of probable Chron 7 age (see discussion following). Apparently the coiling direction changes recorded in $\mathrm{NeO}$ - 
globoquadrina at lower latitudes have little stratigraphic application at higher latitudes.

\section{Other Biostratigraphic Studies of Hole 552A}

Other studies at Hole 552A have focused on benthic foraminifers (Schnitker, 1984), diatoms (Baldauf, 1984), radiolarians (Westberg-Smith and Riedel, 1984), and silicoflagellates (Bukry, 1984). The datum levels from these studies that have been tied to the geomagnetic polarity time scale are plotted in Figure 2. Important late Miocene datum levels for diatoms include a sequence of three first appearances and two last appearances (Baldauf, 1984). Thalassiosira miocenica last occurs at $\sim 104 \mathrm{~m}$ (in Sample 22, CC), at a level considered to mark the Miocene/Pliocene boundary. Silica dissolution below 144 $\mathrm{m}$ prevented recognition of older diatom datum levels, and could possibly explain the positions of some of the diatom FADs in Figure 2. Baldauf (personal communication, 1984) believes, however, that the appearances of T. miocenica and Thalassiosira var. aspinosa do not reflect preservational exclusion from lower levels, since solution-susceptible specimens of Actinoptychus undulatus and Actinocyclus ellipticus were found in an older sample without $T$. miocenica and $T$. var. aspinosa.

The only important radiolarian datum level found in the upper Miocene of Hole 552A is the first appearance of Stichocorys peregrina, which evolved from Stichocorys delmontensis (Westberg-Smith and Riedel, 1984). This FAD occurs between about 134 and $143.5 \mathrm{~m}$, straddling the Chronozone 5/6 boundary (see discussion following), and is unlikely to be affected by silica dissolution, because it is an evolutionary transition. In the equatorial Pacific, the FAD of $S$. peregrina was found in the upper reversed interval of Chronozone 6 (Saito et al., 1975).

Bukry (1984) found that the abundance patterns of silicoflagellates and the sequence of datum levels in Hole $552 \mathrm{~A}$ are very similar to what he has observed in the eastern Pacific, but silicoflagellate stratigraphy has not yet been tied to the geomagnetic polarity time scale. Bukry's best estimate for the silicoflagellate Miocene/Pliocene boundary, which is not well established, is between 108 and $112 \mathrm{~m}$, on the basis of the last occurrence of Dictyocha neonautica in Sample 552A-24-3, 98-99 cm.

\section{MAGNETOSTRATIGRAPHY OF HOLE 552A}

Cores 1 to 12 gave a reliable magnetostratigraphy from the Brunhes Chron to the latest Gilbert, and this was used together with nannofossil, carbon, and oxygen isotopic stratigraphies to document the paleoceanographic and climatic record over the middle Pliocene and Pleistocene (Shackleton, Backman, et al., 1984). Because of coring disturbance and generally very weak magnetizations $\left(<2 \times 10^{-5} \mathrm{~A} / \mathrm{m}\right)$, no reliable magnetostratigraphy was obtained for Cores 13 to 25 . The material recovered in Cores 26 to Core 38 (below $\sim 120 \mathrm{~m}$ ) proved to be generally suitable for paleomagnetic analysis, however, and this work is described here.

Measured remanent inclination data (Table 3, Fig. 4) for 171 samples from between $\sim 120$ and $180 \mathrm{~m}$ sub-bottom generally group around the expected dipole value
Table 3. Paleomagnetic measurements on samples from Cores 26 to 38 from DSDP Hole 552A.

\begin{tabular}{|c|c|c|c|c|}
\hline Number & $\begin{array}{l}\text { Core-Sec, } \\
\text { level }(\mathrm{cm})\end{array}$ & $\begin{array}{l}\text { Sub-bottom } \\
\text { depth } \\
\text { (m) }\end{array}$ & $\mathrm{J}(\mathrm{A} / \mathrm{m})^{\mathrm{a}}$ & $\begin{array}{l}\text { Incl. } \\
\left({ }^{\circ}\right)^{\mathrm{b}}\end{array}$ \\
\hline 1 & $26-1,050$ & 119.00 & $1 \mathrm{E}-04$ & -50.6 \\
\hline 2 & $26-1,095$ & 119.45 & $3 E-05$ & -39.4 \\
\hline 3 & $26-2,049$ & 120.49 & $7 \mathrm{E}-05$ & -33.7 \\
\hline 4 & $26-2,102$ & 121.02 & $3 \mathrm{E}-05$ & -41.7 \\
\hline 5 & $26-2,144$ & 121.44 & $7 E-05$ & -36.2 \\
\hline 6 & $26-3,095$ & 122.45 & $7 \mathrm{E}-05$ & -60.8 \\
\hline 7 & $26-3,144$ & 122.94 & $6 E-05$ & -36.7 \\
\hline 8 & $27-2,049$ & 124.44 & $1.5 \mathrm{E}-04$ & -29.4 \\
\hline 9 & $27-2,094$ & 125.49 & $5 E-05$ & 72.7 \\
\hline 10 & $27-2,144$ & 125.94 & $3 E-05$ & 16.2 \\
\hline 11 & $27-3,049$ & 126.44 & $3 E-05$ & 59.1 \\
\hline 12 & $27-3,102$ & 126.99 & $6 \mathrm{E}-05$ & 71.2 \\
\hline 13 & $27-3,144$ & 127.52 & $9 \mathrm{E}-05$ & 73.4 \\
\hline 14 & $28-2,024$ & 127.94 & $7 E-05$ & 89.4 \\
\hline 15 & $28-2,073$ & 130.24 & $5 \mathrm{E}-05$ & 60.2 \\
\hline 16 & $28-2,099$ & 130.99 & $8 \mathrm{E}-05$ & 78.7 \\
\hline 17 & $28-2,125$ & 131.25 & $9 \mathrm{E}-05$ & 70.9 \\
\hline 18 & $28-2,141$ & 131.41 & 1. $2 \mathrm{E}-04$ & 64.4 \\
\hline 19 & $28-3,047$ & 131.97 & $9 \mathrm{E}-05$ & 81.9 \\
\hline 20 & $28-3,075$ & 132.25 & $3 E-05$ & -50.2 \\
\hline 21 & $28-3,123$ & 132.73 & $2.7 \mathrm{E}-04$ & 7.8 \\
\hline 22 & $28-4,0-1$ & 133.01 & $3 E-05$ & 62.9 \\
\hline 23 & $29-1,075$ & 134.25 & $1 \mathrm{E}-04$ & -65 \\
\hline 24 & $29-1,099$ & 134.49 & $5 E-05$ & -63 \\
\hline 25 & $29-1,125$ & 134.75 & $2 \mathrm{E}-05$ & 79.2 \\
\hline 26 & $29-1,144$ & 134.94 & $5 E-05$ & 54.7 \\
\hline 27 & $29-2,024$ & 135.24 & $6 \mathrm{E}-05$ & 81.5 \\
\hline 28 & $29-2,073$ & 135.73 & $4 \mathrm{E}-05$ & 62.8 \\
\hline 29 & $29-2,127$ & 136.27 & $5 E-05$ & 76.9 \\
\hline 30 & $29-3,025$ & 136.75 & $1.8 \mathrm{E}-04$ & 73.3 \\
\hline 31 & $29-3,074$ & 137.24 & $5 E-05$ & 83.1 \\
\hline 32 & 29-3, 099 & 137.49 & $7 E-05$ & 69.9 \\
\hline 33 & $29-3,123$ & 137.73 & $8 \mathrm{E}-05$ & 72 \\
\hline 34 & $29-3,145$ & 137.95 & $1 \mathrm{E}-04$ & 69.5 \\
\hline 35 & $30-1,047$ & 138.97 & $6 \mathrm{E}-05$ & 81.9 \\
\hline 36 & $30-1,077$ & 139.27 & $7 E-05$ & 71.9 \\
\hline 37 & $30-1,097$ & 139.47 & $8 \mathrm{E}-05$ & 72.5 \\
\hline 38 & $30-1,134$ & 139.84 & $6 \mathrm{E}-04$ & 61.9 \\
\hline 39 & $30-1,144$ & 139.94 & $7 \mathrm{E}-05$ & 30.7 \\
\hline 40 & $30-2,024$ & 140.24 & $2.1 \mathrm{E}-04$ & 79.6 \\
\hline 41 & $30-2,047$ & 140.47 & $7 \mathrm{E}-05$ & 69 \\
\hline 42 & $30-2,073$ & 140.73 & $8 \mathrm{E}-05$ & 65 \\
\hline 43 & $30-2,096$ & 140.96 & $8 \mathrm{E}-05$ & 37.8 \\
\hline 44 & $30-3,048$ & 141.28 & $2 E-05$ & 60.4 \\
\hline 45 & $30-3,074$ & 141.98 & $6 \mathrm{E}-05$ & -82.4 \\
\hline 46 & $30-3,128$ & 142.24 & $7 \mathrm{E}-05$ & -78.2 \\
\hline 47 & $30-3,144$ & 142.94 & $2 E-05$ & -77.4 \\
\hline 48 & $31-1,097$ & 144.47 & $4 \mathrm{E}-05$ & -75.7 \\
\hline 49 & $31-1,123$ & 144.73 & $9 \mathrm{E}-05$ & -55.1 \\
\hline 50 & $31-2,025$ & 145.25 & $5 \mathrm{E}-05$ & -61.5 \\
\hline 51 & $31-2,046$ & 145.46 & $8 \mathrm{E}-05$ & -62.6 \\
\hline 52 & $31-2,075$ & 145.75 & $5 E-05$ & -80 \\
\hline 53 & $31-2,101$ & 146.01 & $4 \mathrm{E}-05$ & -67.4 \\
\hline 54 & $31-2,125$ & 146.25 & $7 E-05$ & -64.4 \\
\hline 55 & $31-2,144$ & 146.44 & $9 \mathrm{E}-05$ & 10.3 \\
\hline 56 & $31-3,025$ & 146.75 & $7 E-05$ & -34.3 \\
\hline 57 & $31-3,052$ & 147.02 & $4 \mathrm{E}-05$ & -61 \\
\hline 58 & $31-3,076$ & 147.26 & $4 \mathrm{E}-04$ & -68.8 \\
\hline 59 & $31-3,097$ & 147.47 & $7 E-05$ & -49.2 \\
\hline 60 & $31-3,126$ & 147.76 & $6 \mathrm{E}-05$ & -63.4 \\
\hline 61 & $31-3,144$ & 147.94 & $1.9 \mathrm{E}-04$ & -71.4 \\
\hline 62 & $32-1,047$ & 148.97 & $1.4 \mathrm{E}-03$ & -67.8 \\
\hline 63 & $32-1,076$ & 149.26 & $2.56 \mathrm{E}-03$ & -77.1 \\
\hline 64 & $32-1,099$ & 149.49 & $2.2 \mathrm{E}-03$ & -71 \\
\hline 65 & $32-1,125$ & 149.75 & $1.13 \mathrm{E}-03$ & -74.2 \\
\hline 66 & $32-1,144$ & 149.94 & $1.18 \mathrm{E}-03$ & -73.5 \\
\hline 67 & $32-2,025$ & 150.25 & $2.8 \mathrm{E}-04$ & 55.1 \\
\hline 68 & $32-2,050$ & 150.50 & $1.3 \mathrm{E}-04$ & 76.2 \\
\hline 69 & $32-2,076$ & 150.76 & $5.1 \mathrm{E}-04$ & 65.2 \\
\hline 70 & $32-2,086$ & 150.86 & $4 \mathrm{E}-04$ & 51.4 \\
\hline 71 & $32-2,102$ & 151.02 & $9 E-05$ & 37 \\
\hline 72 & $32-2,126$ & 151.26 & $8 \mathrm{E}-05$ & 82.3 \\
\hline 73 & $32-2,144$ & 151.44 & $4 E-05$ & -67.4 \\
\hline 74 & $32-3,025$ & 151.75 & $4.4 \mathrm{E}-04$ & -75.9 \\
\hline 75 & $32-3,051$ & 152.01 & $8.3 E-04$ & -66.5 \\
\hline
\end{tabular}


Table 3 (continued).

\begin{tabular}{|c|c|c|c|c|}
\hline Number & $\begin{array}{l}\text { Core-Sec, } \\
\text { level }(\mathrm{cm})\end{array}$ & $\begin{array}{l}\text { Sub-bottom } \\
\text { depth } \\
\text { (m) }\end{array}$ & $\mathrm{J}(\mathrm{A} / \mathrm{m})^{\mathrm{a}}$ & $\begin{array}{l}\text { Incl. } \\
\left({ }^{\circ}\right)^{\mathrm{b}}\end{array}$ \\
\hline 76 & $32-3,076$ & 152.26 & $1.9 E-04$ & 74.4 \\
\hline 77 & $32-3,099$ & 152.49 & $2.1 \mathrm{E}-04$ & 66.8 \\
\hline 78 & $32-3,126$ & 152.76 & $3.8 \mathrm{E}-04$ & 74.8 \\
\hline 79 & $32-3,144$ & 152.94 & $2 E-05$ & 65.9 \\
\hline 80 & $33-1,051$ & 154.01 & $5.6 \mathrm{E}-04$ & 70.4 \\
\hline 81 & $33-1,075$ & 154.24 & $6 E-04$ & 68.6 \\
\hline 82 & $33-1,101$ & 154.51 & $3.3 E-04$ & 70.9 \\
\hline 83 & $33-1,125$ & 154.75 & $5.9 \mathrm{E}-04$ & 69.6 \\
\hline 84 & $33-1,144$ & 154.94 & $2.5 E-04$ & 55.8 \\
\hline 85 & $33-2,025$ & 155.25 & $3.3 \mathrm{E}-04$ & 68.8 \\
\hline 86 & $33-2,052$ & 155.52 & $3.7 \mathrm{E}-04$ & 70.4 \\
\hline 87 & $33-2,075$ & 155.75 & $7 E-05$ & 54.3 \\
\hline 88 & $33-2,099$ & 155.99 & $3.8 \mathrm{E}-04$ & 74.3 \\
\hline 89 & $33-2,125$ & 156.25 & $3.8 \mathrm{E}-04$ & 67.1 \\
\hline 90 & $33-2,144$ & 156.44 & $1.27 \mathrm{E}-03$ & 68.7 \\
\hline 91 & $33-3,025$ & 156.75 & $8.3 E-04$ & 70.6 \\
\hline 92 & $33-3,051$ & 157.01 & $3.1 \mathrm{E}-04$ & 68.6 \\
\hline 93 & $33-3,075$ & 157.25 & $3.2 \mathrm{E}-04$ & 76.4 \\
\hline 94 & $33-3,101$ & 157.51 & $7.3 \mathrm{E}-04$ & 57.6 \\
\hline 95 & $33-3,125$ & 157.75 & $2.7 \mathrm{E}-04$ & 70.1 \\
\hline 96 & $33-3,144$ & 157.94 & $2.2 \mathrm{E}-04$ & 40.7 \\
\hline 97 & $34-1,075$ & 159.25 & $4.2 \mathrm{E}-04$ & 65.3 \\
\hline 98 & $34-1,097$ & 159.47 & $2.5 \mathrm{E}-04$ & 71.2 \\
\hline 99 & $34-1,125$ & 159.75 & $1.9 \mathrm{E}-04$ & 79.5 \\
\hline 100 & $34-1,144$ & 159.94 & $7 \mathrm{E}-05$ & 73 \\
\hline 101 & $34-2,025$ & 160.25 & $5 E-05$ & -82.2 \\
\hline 102 & $34-2,052$ & 160.52 & $1.2 \mathrm{E}-04$ & 56.1 \\
\hline 103 & $34-2,075$ & 160.75 & $2.15 \mathrm{E}-03$ & -13.3 \\
\hline 104 & $34-2,098$ & 160.98 & $3 E-05$ & -9.3 \\
\hline 105 & $34-2,125$ & 161.25 & $4 E-05$ & 79.2 \\
\hline 106 & $35-1,025$ & 163.75 & $2.91 \mathrm{E}-03$ & 70.3 \\
\hline 107 & $35-1,046$ & 163.96 & $4.15 E-03$ & 74.9 \\
\hline 108 & $35-1,074$ & 164.24 & $1.8 \mathrm{E}-04$ & 73.6 \\
\hline 109 & $35-1,097$ & 164.47 & $2.7 \mathrm{E}-04$ & 83.1 \\
\hline 110 & $35-1,144$ & 164.94 & $5 E-05$ & -5.6 \\
\hline 111 & $35-2,047$ & 165.47 & $7 E-05$ & 50.7 \\
\hline 112 & $35-2,075$ & 165.75 & $1.3 \mathrm{E}-03$ & 37.2 \\
\hline 113 & $35-2,098$ & 165.98 & $1.84 \mathrm{E}-03$ & -67.5 \\
\hline 114 & $35-2,125$ & 166.25 & $1.32 \mathrm{E}-03$ & 18.5 \\
\hline 115 & $35-2,144$ & 166.44 & $1.32 \mathrm{E}-03$ & 39.9 \\
\hline 116 & $35-3,025$ & 166.75 & $9.8 \mathrm{E}-04$ & -64.2 \\
\hline 117 & $35-3,047$ & 166.97 & $1.13 E-03$ & 55.9 \\
\hline 118 & $35-3,075$ & 167.25 & $1.64 \mathrm{E}-03$ & 46.5 \\
\hline 119 & $35-3,097$ & 167.47 & $5.5 \mathrm{E}-04$ & -52 \\
\hline 120 & $35-3,125$ & 167.75 & $9 E-04$ & -66.8 \\
\hline 121 & $35-3,144$ & 167.94 & $2.03 \mathrm{E}-03$ & -74.1 \\
\hline 122 & $36-1,047$ & 168.97 & $6 E-05$ & 35.1 \\
\hline 123 & $36-1,096$ & 169.46 & $9.1 \mathrm{E}-04$ & 30 \\
\hline 124 & $36-1,126$ & 169.76 & $1 E-04$ & 77.1 \\
\hline 125 & $36-1,144$ & 169.94 & $1.4 \mathrm{E}-04$ & 53.9 \\
\hline 126 & $36-2,025$ & 170.25 & $9 \mathrm{E}-05$ & 57.4 \\
\hline 127 & $36-2,051$ & 170.51 & $1.8 \mathrm{E}-04$ & 77.2 \\
\hline 128 & $36-2,074$ & 170.74 & $2.5 E-04$ & 78.5 \\
\hline 129 & $36-2,097$ & 170.97 & $5.04 \mathrm{E}-03$ & 71.4 \\
\hline 130 & $36-2,125$ & 171.25 & $2.06 \mathrm{E}-03$ & 69.3 \\
\hline 131 & $36-2,144$ & 171.44 & $3.75 \mathrm{E}-03$ & 68.7 \\
\hline 132 & $36-3,025$ & 171.75 & $2.68 \mathrm{E}-03$ & 73.1 \\
\hline 133 & $36-3,049$ & 171.99 & $4.5 \mathrm{E}-04$ & 72.4 \\
\hline 134 & $36-3,075$ & 172.25 & $5 E-04$ & 2.6 \\
\hline 135 & $36-3,097$ & 172.47 & $4 E-04$ & 75.3 \\
\hline 136 & $36-3,125$ & 172.75 & $1.5 E-04$ & 22.8 \\
\hline 137 & $36-3,144$ & 172.94 & $9 \mathrm{E}-05$ & -19.2 \\
\hline 138 & $37-1,049$ & 173.99 & $4.16 \mathrm{E}-03$ & 59.6 \\
\hline 139 & $37-1,073$ & 174.23 & $9.77 \mathrm{E}-03$ & 45.5 \\
\hline 140 & $37-1,098$ & 174.48 & 0.02911 & 57.1 \\
\hline 141 & $37-1,128$ & 174.78 & 0.01748 & 55.4 \\
\hline 142 & $37-1,143$ & 174.93 & 0.02317 & 64.3 \\
\hline 143 & $37-2,025$ & 175.25 & 0.03774 & 71.6 \\
\hline 144 & $37-2,048$ & 175.48 & 0.01683 & 62.6 \\
\hline 145 & $37-2,076$ & 175.76 & 0.01798 & 66.6 \\
\hline 146 & $37-2,099$ & 175.99 & $4.64 \mathrm{E}-03$ & -55 \\
\hline 147 & $37-2,128$ & 176.28 & $3.74 \mathrm{E}-03$ & -66.1 \\
\hline 148 & $37-2,144$ & 176.44 & $4.8 E-03$ & -35 \\
\hline 149 & $37-3,025$ & 176.75 & 0.0116 & -68.5 \\
\hline 150 & $37-3,049$ & 176.99 & 0.01565 & -62.8 \\
\hline 151 & $37-3,072$ & 177.22 & 0.0172 & -69.3 \\
\hline
\end{tabular}

Table 3 (continued).

\begin{tabular}{|c|c|c|c|c|}
\hline Number & $\begin{array}{l}\text { Core-Sec, } \\
\text { level }(\mathrm{cm})\end{array}$ & $\begin{array}{l}\text { Sub-bottom } \\
\text { depth } \\
\text { (m) }\end{array}$ & $\mathrm{J}(\mathrm{A} / \mathrm{m})^{\mathrm{a}}$ & $\begin{array}{l}\text { Incl. } \\
\left({ }^{\circ}\right)^{b}\end{array}$ \\
\hline 152 & $37-3,096$ & 177.46 & 0.02229 & -55.8 \\
\hline 153 & $37-3,125$ & 177.75 & 0.01434 & -65.6 \\
\hline 154 & $37-3,131$ & 177.81 & 0.01648 & -67.3 \\
\hline 155 & $38-1,048$ & 178.98 & $7.1 \mathrm{E}-03$ & -62.4 \\
\hline 156 & $38-1,075$ & 179.25 & 0.01417 & -60.6 \\
\hline 157 & $38-1,099$ & 179.49 & 0.01062 & -35.8 \\
\hline 158 & $38-1,125$ & 179.75 & 0.01595 & -48.1 \\
\hline 159 & $38-1,144$ & 179.94 & 0.01892 & -62.8 \\
\hline 160 & $38-2,023$ & 180.23 & 0.01411 & -66.9 \\
\hline 161 & $38-2,044$ & 180.44 & 0.01964 & -65.7 \\
\hline 162 & $38-2,076$ & 180.76 & $7.73 E-03$ & -52.3 \\
\hline 163 & $38-2,099$ & 180.99 & 0.01075 & -57.6 \\
\hline 164 & $38-2,125$ & 181.25 & 0.01594 & -62.4 \\
\hline 165 & $38-2,144$ & 181.44 & 0.02426 & -64.7 \\
\hline 166 & $38-3,023$ & 181.73 & $9.73 \mathrm{E}-03$ & -60 \\
\hline 167 & $38-3,047$ & 181.97 & $9.7 \mathrm{E}-03$ & -50.4 \\
\hline 168 & $38-3,072$ & 182.22 & $9.61 \mathrm{E}-03$ & -65.1 \\
\hline 169 & $38-3,101$ & 182.51 & 0.02377 & -67.6 \\
\hline 170 & $38-3,125$ & 182.75 & 0.02182 & -70.2 \\
\hline 171 & $38-4,010$ & 183.10 & 0.0212 & 81.3 \\
\hline
\end{tabular}

a Intensity of magnetization $J$ after AF demagnetization to $10 \mathrm{mT}$. Number after the $\mathrm{E}$ is exponent to base 10: for example, $1 \mathrm{E}-04=1 \times 10^{-4} ; 3 \mathrm{E}-05=3 \times 10^{-5}$; $7 \mathrm{E}-05=7 \times 10^{-5}$.

$\mathrm{b}$ Inclination after AF demagnetization to $10 \mathrm{mT}$.

$\left(71^{\circ}\right.$, positive sign for normal and negative sign for reversed) for the latitude of the site, and we therefore suggest that a reliable record of geomagnetic polarity has been obtained. Excluded are data from 9 samples inadvertently taken from disturbed sections of core (according to barrel sheet descriptions) and also from 17 samples where NRM intensities approach the practical noise level of the magnetometer $\left(2 \times 10^{-5} \mathrm{~A} / \mathrm{m}\right.$ for a $6.6-\mathrm{cm}^{3}$ sample). Only orientation with respect to the vertical axis of the cores was preserved, so that the inclination component is used to infer magnetization polarity at this high-latitude site. Accordingly, our interpretation of magnetic polarity is indicated in the bar graph in Figure 4, filled for normal and open for reversed polarity.

Anomalously short upper middle to lower upper Miocene intervals (Zones NN7-NN10) at Hole 552A suggest multiple hiatuses below $\sim 160 \mathrm{~m}$. Magnetostratigraphic correlations within this interval are correspondingly uncertain and so are not given.

From $158 \mathrm{~m}$ to at least $120 \mathrm{~m}$, however, there appears to be a more continuous record of the late Miocene, with a more diagnostic magnetostratigraphy. We believe that the normal magnetozone between $\sim 160$ and 152.13 m correlates with Chron C4N (partim) (magnetostratigraphic Chron 7) by biostratigraphic and isotope stratigraphic comparison with Hole 611C (see later discussion). The overlying dominantly reversed magnetozone, which extends up to $141.63 \mathrm{~m}$, very likely correlates with Chron C3AR (Chron 6); the short normal magnetozone at $\sim 151 \mathrm{~m}$ is included in Chron C3AR. This interpretation is supported by the position of the FAD of $\mathrm{A}$. pri$m u s$, which has been shown to occur in Chronozone 6 (Haq et al., 1980), and by carbon isotope stratigraphy (see later discussion). We favor the interpretation that the normal-reversed-normal sequence from 141.63 to $124.97 \mathrm{~m}$ represents just the lower normal interval of 


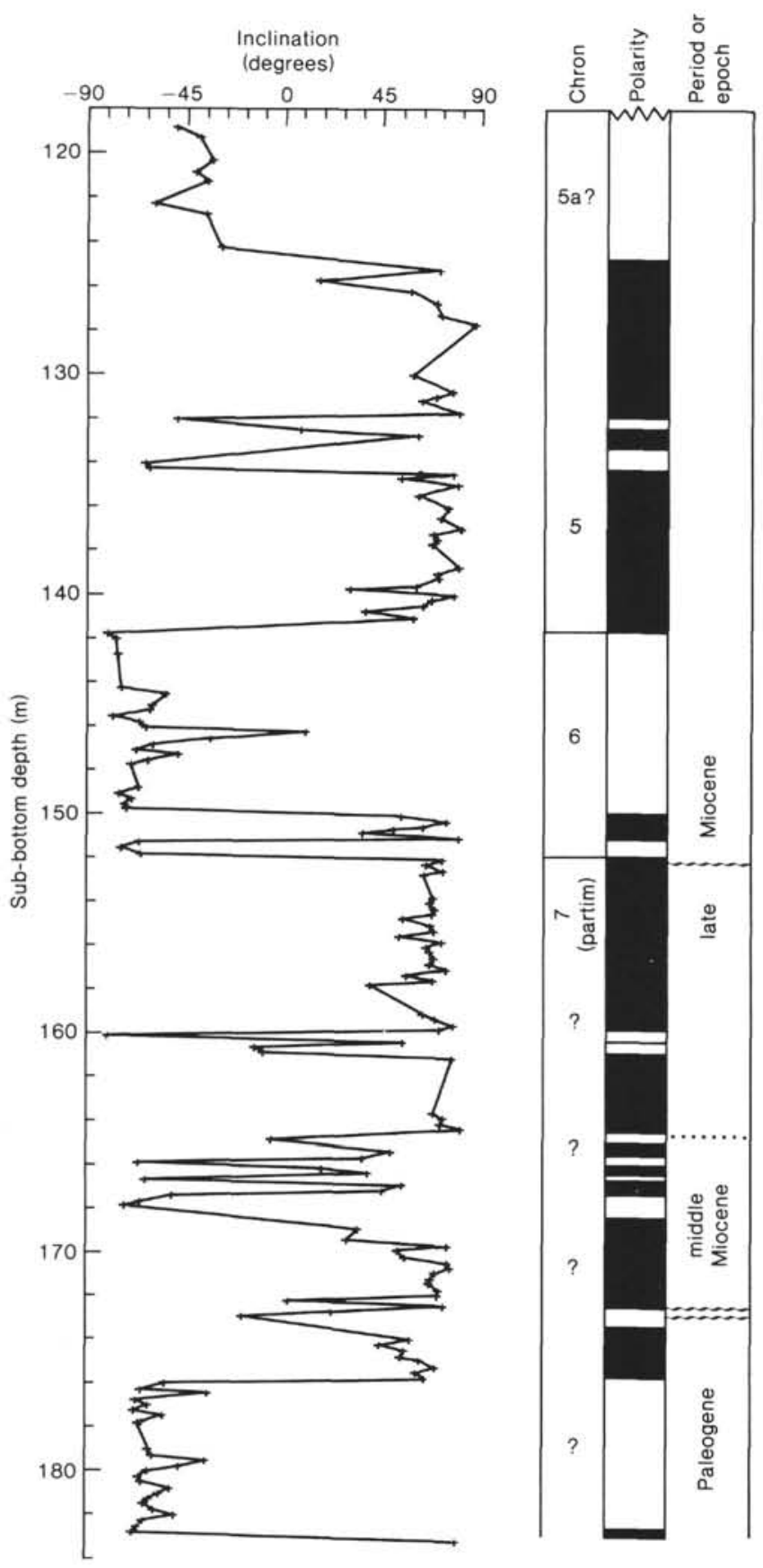

Figure 4. Magnetic inclination results for Hole 552A. Magnetostratigraphy is based on interpretation of inclination values and not declination values, because orientation was preserved only with respect to the vertical axis of each core.

Chron 5 with short reversed intervals, although it could possibly represent all of Chron 5. Unfortunately, no useful magnetostratigraphic data in the critical interval (119$60 \mathrm{~m}$ ) were obtained, leaving open the two possible correlations.

Our favored alternative (solid line, Fig. 2) suggests that the reversals between 132 and $135 \mathrm{~m}$ are not commonly recognized. This is possible, because most previous paleomagnetic records have been based on less intensive sampling, but a very short reversal within lower Chronozone 5 was previously recognized in equatorial
Pacific Core RC12-66 (Foster and Opdyke, 1970). At Hole 552A two short reversals fall within the interval we tentatively date as 5.75 to $5.80 \mathrm{Ma}$. In support of this paleomagnetic interpretation, it should be noted that small reversals are also indicated in near-bottom geophysical profiles of the older part of Anomaly $3 \mathrm{~A}$ (correlative to Chron 5) at the Juan de Fuca Ridge and the East Pacific Rise at $21^{\circ} \mathrm{N}$ (Klitgord et al., 1975).

\section{STABLE-ISOTOPE STRATIGRAPHY AT HOLE 552A}

Stable-isotope results (Appendix) for Hole 552A reveal systematic patterns of variability in both $\delta^{18} \mathrm{O}$ and ${ }^{13} \mathrm{C}$ (Figs. 5 and 6). Although there appears to be some periodicity in the $\delta^{18} \mathrm{O}$ record of the planktonic foraminifer $\mathrm{G}$. bulloides, it is not so evident in the record of Planulina wuellerstorfi (Fig. 5). Overall, the planktonic foraminiferal $\delta^{18} \mathrm{O}$ record shows a higher-amplitude signal, which may be more useful for local correlation than the results from benthic foraminifers. Notable events of ${ }^{18} \mathrm{O}$ enrichment occur at $\sim 106$ and $\sim 119 \mathrm{~m}$ in benthic and planktonic foraminifers.

Carbon isotope results for benthic and planktonic foraminifers also covary (Fig. 6). As with $\delta^{18} \mathrm{O}$, the $\delta^{13} \mathrm{C}$ record of $G$. bulloides has a higher-amplitude signal. The most prominent feature in the carbon isotope record is the decrease in upper Miocene $\delta^{13} \mathrm{C}$ values between about 145 and $150 \mathrm{~m}$, within Chronozone 6 . This change, which has been widely reported in studies of the late Miocene (Keigwin, 1979; Vincent et al., 1980; Shackleton et al., 1984; among others), has only twice been dated (at $\sim 6.2$ Ma) using paleomagnetic stratigraphy (Loutit and Kennett, 1979; Keigwin and Shackleton, 1980). Intensive sampling at Hole 552A suggests a low-frequency $\sim 2$-m.y. wavelength change in $\delta^{13} \mathrm{C}$, with maxima at $\sim 110$ and $\sim 160 \mathrm{~m}$. Superimposed on this pattern is a long-term decrease in $\delta^{13} \mathrm{C}$; the combination results in the "carbon shift" at $\sim 6.2 \mathrm{Ma}$. This low-frequency variability may explain why relatively coarse sampling of the upper Miocene at some sites (e.g., Site 289; Woodruff et al., 1981) revealed a gradual rather than an abrupt decrease in $\delta^{13} \mathrm{C}$. High-frequency covariance in benthic and planktonic $\delta^{13} \mathrm{C}$ is evident throughout the interval where samples are spaced $10 \mathrm{~cm}$ apart, and is especially great above $120 \mathrm{~m}$. Such covariance suggests that there is a compositional signal in the $\delta^{13} \mathrm{C}$ of total $\mathrm{CO}_{2}$ in seawater.

\section{SEDIMENTATION RATES AND STRATIGRAPHIC SUMMARY OF HOLE 552A}

Most of our stratigraphic interpretation of the late Miocene at Hole 552A hinges on three observations at about the same stratigraphic level $(\sim 142-153 \mathrm{~m})$ : the first occurrence of Amaurolithus spp., the decrease in $\delta^{13} \mathrm{C}$ values, and the presence of reversely magnetized sediment. The coincidence of these strongly suggests that the reversely magnetized sediment is of Chron 6 age, and from this level we can interpret the age of events higher and lower in the sediment column. It should be kept in mind, however, that much of what is known about latest Miocene biostratigraphy (Gartner, 1973; Saito et al., 1975; Haq et al., 1980), magnetostratigraphy (Foster 


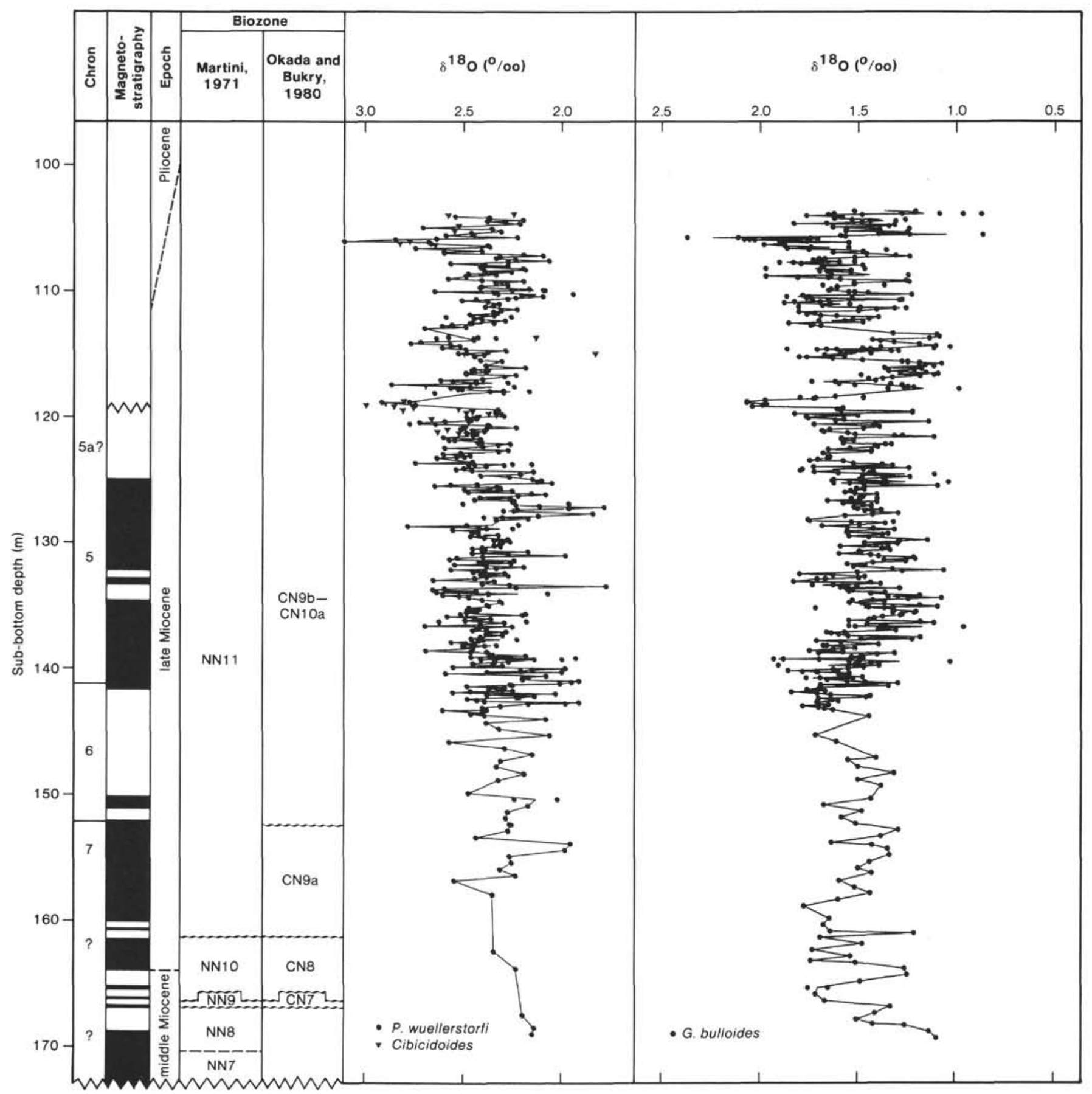

Figure 5. Oxygen isotope results for Hole 552A. Note events of $\delta^{18} \mathrm{O}$ enrichment in benthic and planktonic foraminifers at 104 and $119 \mathrm{~m}$, which we interpret as evidence for brief glaciations at about 5.0 and $\sim 5.5 \mathrm{Ma}$.

and Opdyke, 1970), and carbon-isotope stratigraphy (Loutit and Kennett, 1979; Keigwin and Shackleton, 1980) ultimately depends on cores from the equatorial Pacific, especially RC12-66.

Berggren et al. (in press) report the first appearance of Amaurolithus primus to have occurred at $6.5 \mathrm{Ma}$. At Hole 552A this species first occurs at $152.25 \mathrm{~m}, \sim 1 \mathrm{~m}$ below magnetic reversal $6 \mathrm{a} 1(151.35 \mathrm{~m})$, which is dated at $6.50 \mathrm{Ma}$. Thus, the FAD of $A$. primus must be older than $6.50 \mathrm{Ma}$, but probably no older than $6.7 \mathrm{Ma}$, the age of oldest Chronozone 6 sediment. As discussed earlier, the simultaneous appearance of $A$. primus and $G$. globulata, followed immediately by the appearance of $A$. delicatus and $A$. amplificus, suggests an unconformity at $\sim 152 \mathrm{~m}$. This interpretation is also supported by the presence of the Chronozone 6/Chronozone 7 boundary at the same level, which would result in a sedimentation rate of $\sim 4 \mathrm{~m} / \mathrm{m}$.y. for the interval $\sim 151$ to $\sim 152$ $\mathrm{m}$. The sedimentation rate was similarly low (compared with that of the overlying sediment) between the FAD of 


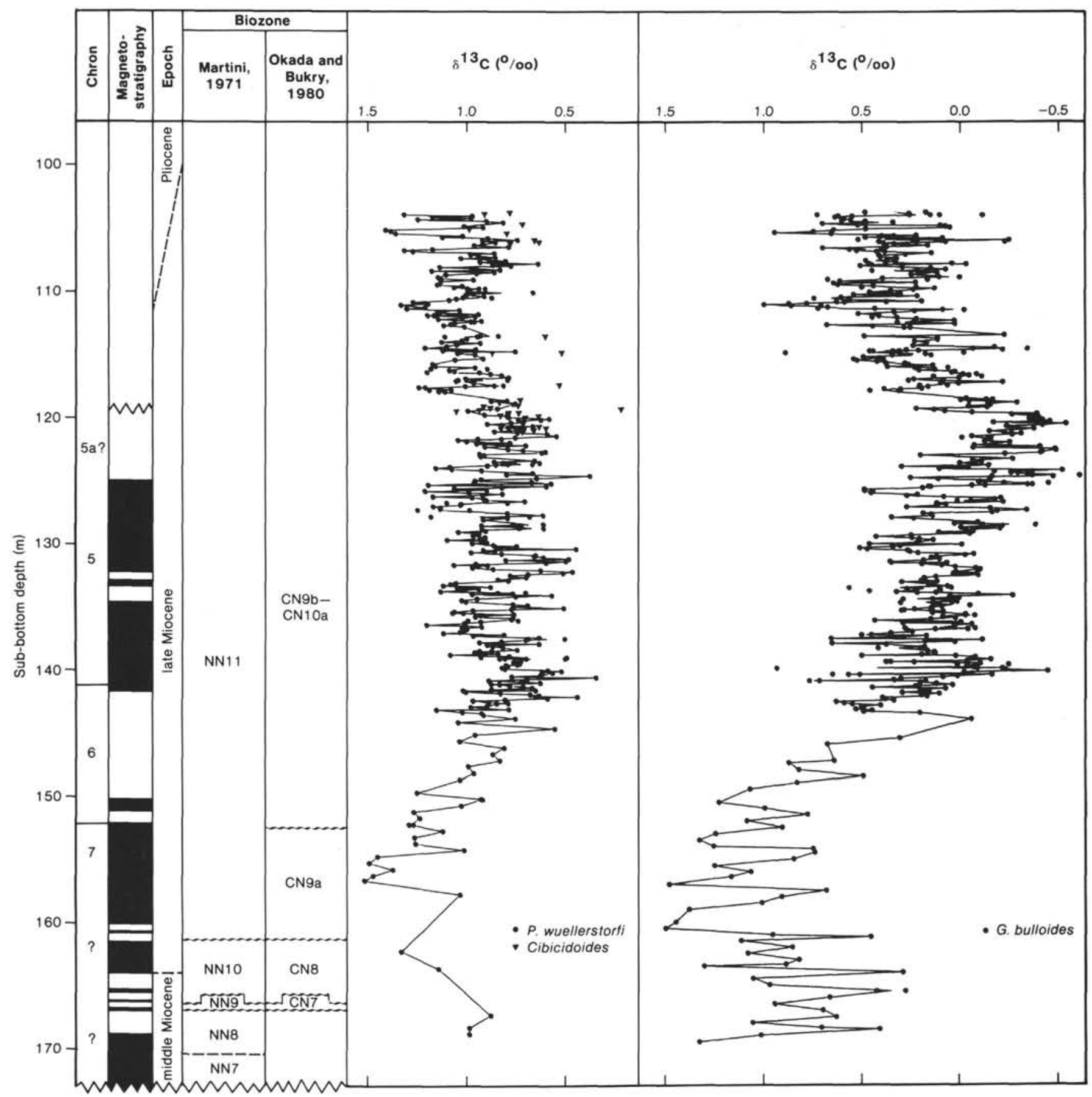

Figure 6. Carbon isotope results for Hole 552A. Note general covariance in $\delta^{13} \mathrm{C}$ patterns of benthic and planktonic foraminifers, which suggests changing $\delta^{13} \mathrm{C}$ of total $\mathrm{CO}_{2}$ in seawater. At $\sim 7 \mathrm{Ma}\left(\sim 155 \mathrm{~m}\right.$ sub-bottom), there is a maximum in $\delta^{13} \mathrm{C}$ of $P$. wuellerstorfi coincident with the coiling shift in Neogloboquadrina. These same events occur together at Holes $610 \mathrm{E}$ (Fig. 11) and $611 \mathrm{C}$ (Fig. 10). As observed elsewhere, $\delta^{13} \mathrm{C}$ values decrease within sediment corresponding to late Chron $6(\sim 6.2 \mathrm{Ma})$ and then increase somewhat above $120 \mathrm{~m}$, where we have no paleomagnetic age control. This suggests a 2-m.y. fluctuation in the ocean's carbon isotope composition. Where the section was sampled in detail, higher-frequency periodicity is also evident; this may reflect an orbital influence on $\delta^{13} \mathrm{C}$ in the ocean.

D. quinqueramus (8.2 Ma, $161.5 \mathrm{~m})$ and the first $A$. primus $(\sim 6.6 \mathrm{Ma}, 152.25 \mathrm{~m})$. This suggests that there may be at least one additional upper Miocene unconformity below $152 \mathrm{~m}$. An upper Miocene unconformity within Zone NN11 also seems to be present elsewhere in the Atlantic Ocean (Aubry, in preparation). Because of the possibility of an additional unconformity between 152 and
$155 \mathrm{~m}$, we cannot be certain that the Neogloboquadrina coiling shift occurred at $7 \mathrm{Ma}$. The normally magnetized sediment between $\sim 152$ and $160 \mathrm{~m}$ (Fig. 4) could represent the younger normal in Chronozone 9, which would still be within Zone NN11 (Fig. 3). In this interpretation, the coiling change would have occurred closer to $8 \mathrm{Ma}$ (dashed line, Fig. 2). A simpler interpretation is 
that the sedimentation rate was uniformly lower at Site 552 before $6 \mathrm{Ma}$ (solid line, Fig. 2). We favor this alternative because it is most consistent with results for Hole 611C (see discussion following).

By earliest Chron 5 time, the rate of sedimentation had increased to $79 \mathrm{~m} / \mathrm{m} . \mathrm{y}$., assuming that the magnetic reversal at $125 \mathrm{~m}$ is $5 \mathrm{a} 1$ (Fig. 2). This is a fair assumption because our preferred interpretation of the data in Figure 2 (solid line) is a better fit to the faunal datum levels between $\sim 130$ and $140 \mathrm{~m}$ sub-bottom, and to the LAD of Thalassiosira miocenica (Baldauf, 1984).

The age of the LAD of $D$. quinqueramus is uncertain, and the highest observed occurrence of this species at $\sim 103 \mathrm{~m}$ cannot be used as a datum level, because it was found in the youngest samples we examined. Thus, it could range even higher in the section at Hole 552A, but above $\sim 103 \mathrm{~m}$ coring disturbance increases. Gartner (1973) reported that $D$. quinqueramus last occurred in Core RC12-66 near the beginning of the upper normal event of Chronozone 5 ( $\sim 5.6 \mathrm{Ma})$. If our last occurrence of $D$. quinqueramus is assumed to be a datum level for $5.6 \mathrm{Ma}$, then the sedimentation rate was $275 \mathrm{~m}$ / m.y. for the interval 103 to $125 \mathrm{~m}$. Although time scale "b" is a good fit to the FAD of G. margaritae and the last appearance(?) of $D$. quinqueramus, which occur at nearly the same level in Core RC12-66 (compare Gartner, 1973 and Saito et al., 1975), we consider the resulting sedimentation rate at Site 552 to be unbelievably high.

As a compromise between the extremes of time scales "a" and "b," we assume a constant sedimentation rate between magnetic reversal $5 \mathrm{a} 1$ and the Gilbert/Gauss boundary (solid line in Fig. 2). This assumption results in age estimates of between $\sim 5.0$ and 5.3 Ma for markers for the Miocene/Pliocene boundary, in best agreement with the estimates of Berggren et al. (in press).

\section{COMPARISON OF RESULTS FOR HOLE 552A WITH THOSE FOR OTHER NORTH ATLANTIC SITES}

For various reasons, other North Atlantic DSDP sites have proved less suitable for detailed isotopic study than Site 552. Problems at other sites include drilling disturbance, incomplete recovery, $\mathrm{CaCO}_{3}$ dissolution, poor biostratigraphic resolution, and post-depositional alteration of the stable-isotope signal. In addition, disagreement between authors about the first and last appearances of critical marker species complicates comparison of species ranges at the various sites. There is difficulty in identifying $D$. quinqueramus in poorly and moderately preserved assemblages. Discoaster quinqueramus can be distinguished from $D$. pentaradiatus and other related forms like Discoaster misconceptus by its non-birefringence in cross-polarized light, in contrast with the black lines formed in the other two species. For instance, its reported occurrence in the lower Pliocene (as high as Zone NN15) in cores from the Rio Grande Rise (Haq and Berggren, 1978) resulted from taxonomic confusion, probably with Discoaster pentaradiatus. Reexamination of the cores studied by Haq and Berggren (1978) suggests that the LAD of $D$. quinqueramus is a reliable datum plane close to the first occurrence of $C$. acutus (Aubry, in prep- aration). Also, the distinction between $D$. quinqueramus and $D$. berggrenii is not always clear, and the relations between these two forms are not well established. Some authors (e.g., Muller, 1974) regard the latter as a smaller variety of the former. Nevertheless, at four out of five additional sites studied for stable isotopes, correlations can be made with the Hole 552A record, demonstrating the usefulness of upper Miocene stable-isotope stratigraphy in the North Atlantic region. Stable-isotope data for these sites are presented in the Appendix, and a summary of biostratigraphic and isotope stratigraphic markers is presented in Figure 7.

\section{Site 410}

Site 410 is on the western flank of the Mid-Atlantic Ridge, in the central North Atlantic (Table 1, Fig. 1). Sediment from Site 410 is a long sequence of nannofossil ooze and chalk extending through the upper Miocene. Planktonic foraminiferal biostratigraphic markers (Fig. 7) are uncommon in upper Miocene sediment, excepting the FAD of Globorotalia conomiozea at $216.5 \mathrm{~m}$ (Poore, 1979), which is a good marker for the base of the Kapitean Stage in New Zealand $(\sim 6.1 \mathrm{Ma}$; Loutit and Kennett, 1979). That level is probably close to the base of the Messinian Stage in the Mediterranean (Berggren et al., in press). Poore (1979) noted the first occurrence of Globorotalia margaritae, thought to be a marker for the uppermost Miocene, at $210.6 \mathrm{~m}$, but in a later work fixed the Miocene/Pliocene boundary at $173 \mathrm{~m}$ on the basis of "the highest unequivocal late Miocene" (Poore, 1981a, p. 603). Elsewhere, Poore (1981b) reported that lowermost Pliocene sediment was found at $167 \mathrm{~m}$, on the basis of the occurrence of Globorotalia puncticulata and Ceratolithus rugosus.

At Site 410 typical $G$. margaritae margaritae have also been seen by one of us (LDK) at $198.3 \mathrm{~m}$. The boundary between the preglacial and glacial Pliocene is set in the present study (Fig. 8) at the first in situ occurrence of ice-rafted debris at this site $(140 \mathrm{~m}$; Luyendyk, Cann, et al., 1979), a level probably equivalent to $2.4 \mathrm{Ma}$ in the North Atlantic (Shackleton, Backman, et al., 1984). Ranges of Discoaster quinqueramus and Amaurolithus spp. at Site 410 have been reported by a few workers and are not in agreement. Bukry (1979) reported the FAD of A. primus at $207 \mathrm{~m}$, but Poore (1981a) later identified the FAD of the genus Amaurolithus at $222.5 \mathrm{~m}$. Bukry (1979) found the FAD of $D$. quinqueramus at $219 \mathrm{~m}$, Poore (1981) reported it much lower (254.5 m), and Steinmetz (1979) reported finding this species in the deepest sediment from this site, with an increase from rare to few specimens at $297.5 \mathrm{~m}$.

Smaller Neogloboquadrina exhibit a shift in coiling preference from dominantly right to left coiling at about $240 \mathrm{~m}$ (Table 2, Fig. 7), but $N$. atlantica is very rare in our samples and in those examined by Poore (1979). Since Poore (1981a) found no permanent change in abundance of $N$. pachyderma s.1., Neogloboquadrina spp., or other cool-water indicators, this coiling shift in specimens $<300 \mu \mathrm{m}$ is unlikely to have resulted from climatic change. At some time during the preglacial Pliocene, coiling again returned to dominantly right. At Hole 552A, 

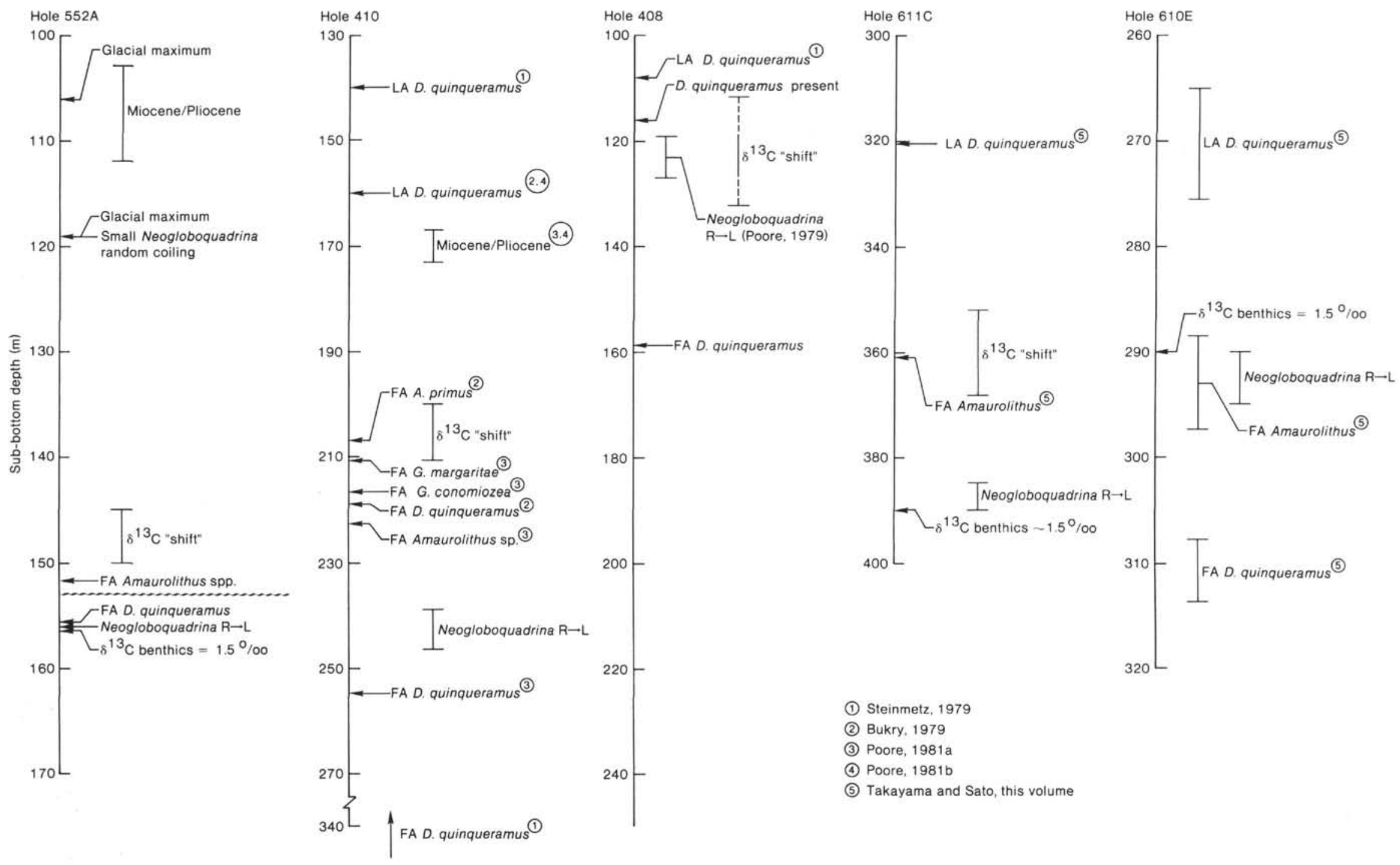

(1) Steinmetz, 1979

(2) Bukry, 1979

(3) Poore, 1981a

(4) Poore, $1981 \mathrm{~b}$

(5) Takayama and Sato, this volume

igure 7. Summary of biostratigraphic and isotope stratigraphic results for DSDP Holes 552A, 410,408, 611C, and 610E. Note that at three sites (Holes 552A, 611C, and 610E) the coiling shift in Neogloboquadrina co-occurs with a maximum of $\delta^{13} \mathrm{C}$ of $1.5 \%$ in $P$. wuellerstorfi. These events are followed by the FAD of Amaurolithus and the $\delta^{13} \mathrm{C}$ "shift" at Holes $552 \mathrm{~A}, 410$, and $611 \mathrm{C}$, but at Hole $610 \mathrm{E}$ the FAD of Amaurolithus is reported by Takayama and Sato (this volume) from a level equivalent to that of the coiling change and $\delta^{13} \mathrm{C}$ maximum. 


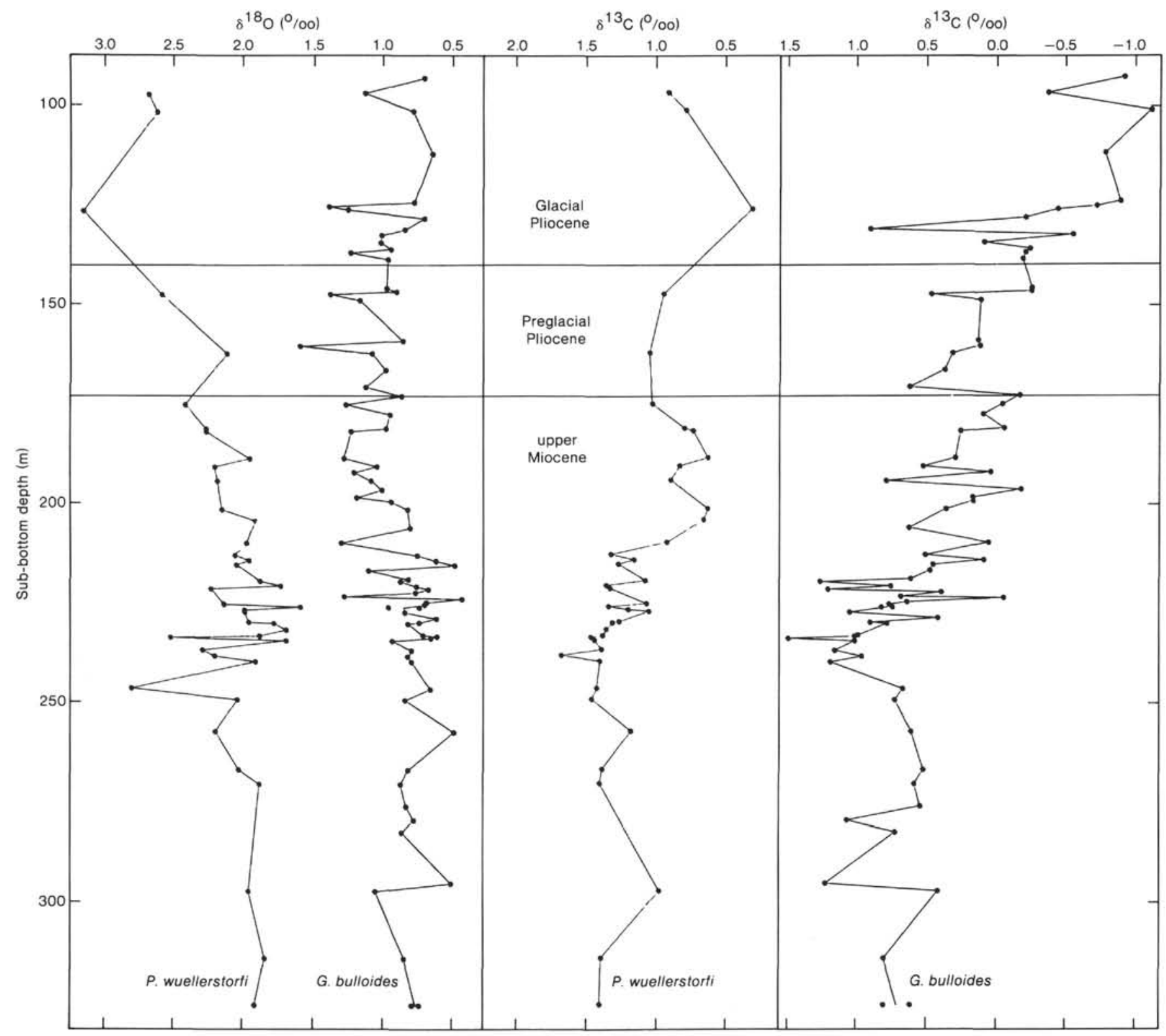

Figure 8. Stable-isotope results for Site 410 . The most prominent feature in this record is the decrease at $\sim 120 \mathrm{~m}$ sub-bottom in benthic and planktonic foraminiferal $\delta^{13} \mathrm{C}$ values.

the right to left coiling change in the genus probably occurred within Chronozone 7, after the first appearance of $D$. quinqueramus, but inconsistencies in identification of $D$. quinqueramus by different authors prevent us from tying its FAD to Neogloboquadrina coiling at Site 410.

Site 410 was not sampled closely enough to permit correlation of the $\delta^{18} \mathrm{O}$ record with that of Hole $552 \mathrm{~A}$, and because of coring disturbance and incomplete recovery such correlation is probably not possible. The carbon isotope record, however, is correlatable between the two sites, using the $\delta^{13} \mathrm{C}$ shift. The simultaneous decrease in $\delta^{13} \mathrm{C}$ of planktonic and benthic foraminifers between $\sim 200$ and $210 \mathrm{~m}$ and the nearly synchronic FAD of Amaurolithus mark the carbon isotope shift at Site 410 (Fig. 8). Below $\sim 210 \mathrm{~m}, \delta^{13} \mathrm{C}$ values of $P$. wueller- storfi are between 1.0 and $1.5 \%$, and above that level, upper Miocene values are between 0.5 and $1.0 \%$. A similar range of values was seen at Hole 552A (Fig. 6). Likewise, about the same $\delta^{13} \mathrm{C}$ values were seen in $\mathrm{G}$. bulloides at each site, although a strong $\delta^{13} \mathrm{C}$ gradient in modern surface waters between 45 and $50^{\circ} \mathrm{N}$ (Kroopnick, 1980) suggests that correlations should be made on the basis of patterns in ${ }^{13} \mathrm{C}$ enrichment rather than magnitude of enrichment. Since the $\delta^{13} \mathrm{C}$ of total $\mathrm{CO}_{2}$ in the deep North Atlantic above $3 \mathrm{~km}$ is relatively uniform (Kroopnick, 1980), it is reasonable to make first-order correlations based on the ${ }^{13} \mathrm{C}$ enrichment in $P$. wuellerstorfi. Although Site 410 and Hole 552A can be correlated using Neogloboquadrina coiling, the FAD of Amaurolithus, and carbon isotopes, we can explain the occurrence of G. margaritae in 6-Ma sediment at Site 410 
only by invoking sample contamination or migration of this species to the latitude of Hole 552A about $1 \mathrm{~m}$.y. after its evolutionary appearance at Site 410 . The latter circumstance would make the FAD of $G$. margaritae at Site 410 about 0.5 m.y. older than the FAD reported for the equatorial Pacific (Saito et al., 1975).

\section{Site $\mathbf{4 0 8}$}

This site was drilled on the west flank of the Reykjanes Ridge at $1624 \mathrm{~m}$ water depth (Luyendyk, Cann, et al., 1979). Biostratigraphy (Fig. 7) is discussed by Poore (1979), Bukry (1979), and Steinmetz (1979). Assignment of the middle Miocene/upper Miocene and Miocene/ Pliocene boundaries is imprecise because of the extreme scarcity or absence of low-latitude marker species. Poore (1979) considered the Miocene/Pliocene boundary to be at about $120 \mathrm{~m}$, on the basis of the coiling change in $N$. atlantica, but we consider this boundary to be higher, since the $N$. atlantica coiling change was a late Miocene event. Steinmetz (1979) found D. quinqueramus between 108 and $159 \mathrm{~m}$, and Bukry (1979) reported this species in one sample from $\sim 116 \mathrm{~m}$ sub-bottom. Neither of these workers reported Amaurolithus in sediment from Site 408. From Hole 552A it appears that the LAD of $D$. quinqueramus is close to other markers for the Miocene/Pliocene boundary. If the coiling change in Neogloboquadrina at $\sim 120 \mathrm{~m}$ is synchronic with the change at Hole 552A, then the uppermost Miocene is probably a condensed interval with about $20 \mathrm{~m}$ of sediment accumulation in $\sim 2$ m.y. This interval also contains the carbon isotope shift (Fig. 9).

Oxygen isotope results for Site 408 are different from those for other sites of this study, because of progressive enrichment in ${ }^{18} \mathrm{O}$ in both benthic and planktonic foraminifers, from the Miocene to the Pliocene (Fig. 9). Increasing $\delta^{18} \mathrm{O}$ in the middle Miocene probably records increased glaciation in Antarctica, which is well documented at many locations (e.g., Woodruff et al., 1981). Unfortunately, biostratigraphic age-control is too poor to prove this assertion. Further $\delta^{18} \mathrm{O}$ increase in the upper Miocene and lower Pliocene may reflect cooling of deep and intermediate waters at this latitude $\left(63^{\circ} \mathrm{N}\right)$. Throughout the upper Miocene, $\delta^{18} \mathrm{O}$ values in benthic foraminifers at Site 408 are several tenths per mil lower than at Hole 552A, suggesting that the intermediate water overlying Site 408 was about $2^{\circ} \mathrm{C}$ warmer than the water over Hole 552A, which is deeper today by $\sim 700 \mathrm{~m}$. By the early Pliocene, the bottom water over Site 408 had cooled to about the same temperature as water over Hole $552 \mathrm{~A}$. As at Site 410 , the quality of sediment recovered at Site 408 prevents detailed stable-isotope correlations with Hole 552A.

\section{Hole 611C}

Hole $611 \mathrm{C}$, on the Gardar Drift, has the best upper Miocene paleomagnetic stratigraphy of Leg 94 sites (Clement and Robinson, this volume). Biostratigraphic markers are scarce, but Takayama and Sato (this volume) found the FAD of Amaurolithus spp. at $361 \mathrm{~m}$ sub-bottom, within paleomagnetic Chronozone 6 (Fig. 7). Samples were taken for stable-isotope studies at 1 -m inter- vals, where possible, but breaks in core recovery and severe $\mathrm{CaCO}_{3}$ dissolution throughout the section resulted in a discontinuous time-series (Fig. 10). The right to left coiling shift in Neogloboquadrina occurred in paleomagnetic Chron 7, at the same time as a maximum in $\delta^{13} \mathrm{C}$ of $P$. wuellerstorfi of $1.5 \%$. This is in excellent agreement with results for Hole 552A. In contrast with Hole $552 \mathrm{~A}$, the sedimentation at Hole $611 \mathrm{C}$ was continuous, and its rate did not decrease for sediment older than $\sim 6 \mathrm{Ma}$ (Fig. 10). This suggests that at Hole 552A the sediment of normal polarity, in which the coiling change of Neogloboquadrina is recorded, is the upper part of Chronozone 7.

As at Hole $552 \mathrm{~A}, \delta^{13} \mathrm{C}$ in benthic and planktonic foraminifers from Hole $611 \mathrm{C}$ decreases in the upper reversed interval of paleomagnetic Chronozone 6 . Above $350 \mathrm{~m}$, the $\delta^{13} \mathrm{C}$ of $P$. wuellerstorf $i$ averages close to $1 \%$ (Fig. 10), the same as the post $-\delta^{13} \mathrm{C}$-shift value at Hole 552A.

Oxygen isotope results for Site 611C differ significantly from those for Hole 552A, because of diagenesis. The $\delta^{18} \mathrm{O}$ of benthic and planktonic specimens is lower by almost $1 \%$, and yet Hole $611 \mathrm{C}(3230 \mathrm{~m})$ is in water $1 \mathrm{~km}$ deeper. Maximum $\delta^{18} \mathrm{O}$ of $P$. wuellerstorfi at Hole $552 \mathrm{~A}$ is nearly $3 \%$, but is only $\sim 2 \% 0$ at Hole $611 \mathrm{C}$. Well-preserved specimens of benthic foraminifers from the water depth of Hole $611 \mathrm{C}$ would be expected to have $\delta^{18} \mathrm{O}$ at least as great as those from Hole 552A. We interpret lower $\delta^{18} \mathrm{O}$ values as evidence of diagenetic alteration of the $\delta^{18} \mathrm{O}$ signal by carbonate dissolution and precipitation at elevated in situ temperatures, although alteration is not as obvious as at other sites, where $\delta^{18} \mathrm{O}$ is lowered by $1 \% 0$ (the middle Miocene of Site 158 , for example; Keigwin, 1979). Nevertheless, carbonate diagenesis is a first-order function of burial depth (Schlanger and Douglas, 1974), the upper Miocene sediments of Hole $611 \mathrm{C}$ are the most deeply buried of this study, and the ${ }^{18} \mathrm{O}$ depletion increased with burial depth. Diagenesis probably has not severely affected the $\delta^{13} \mathrm{C}$ record, because the temperature coefficient for carbon isotope fractionation is about a factor of 10 less than that for oxygen isotopes (Emrich et al., 1970).

\section{Hole 610E}

This hole (Fig. 11), cored on the crest of the Feni Drift, was sampled on board Challenger when preliminary paleomagnetic measurements indicated that Chronozone 6 sediment was recovered. Subsequent paleomagnetic sampling yielded ambiguous results (Clement and Robinson, this volume). Nannofossil biostratigraphy (Takayama and Sato, this volume) places sediment below $174 \mathrm{~m}$ in Hole 610E within Zone NN11, on the basis of the range of $D$. quinqueramus from about 320 to $274 \mathrm{~m}$ and the first occurrence of Amaurolithus spp. between $\sim 289$ and $297 \mathrm{~m}$ (Fig. 7). Diatom biostratigraphy was impossible, owing to silica dissolution (Baldauf, this volume). Counts of Neogloboquadrina coiling direction show the left to right coiling change occurs between 290 and $295 \mathrm{~m}$ (Table 2).

As at other sites, carbon isotope results follow distinct trends. At Hole $610 \mathrm{E}$, however, the prominent change in $G$. bulloides is from ${ }^{13} \mathrm{C}$ depletion to ${ }^{13} \mathrm{C}$ enrichment 


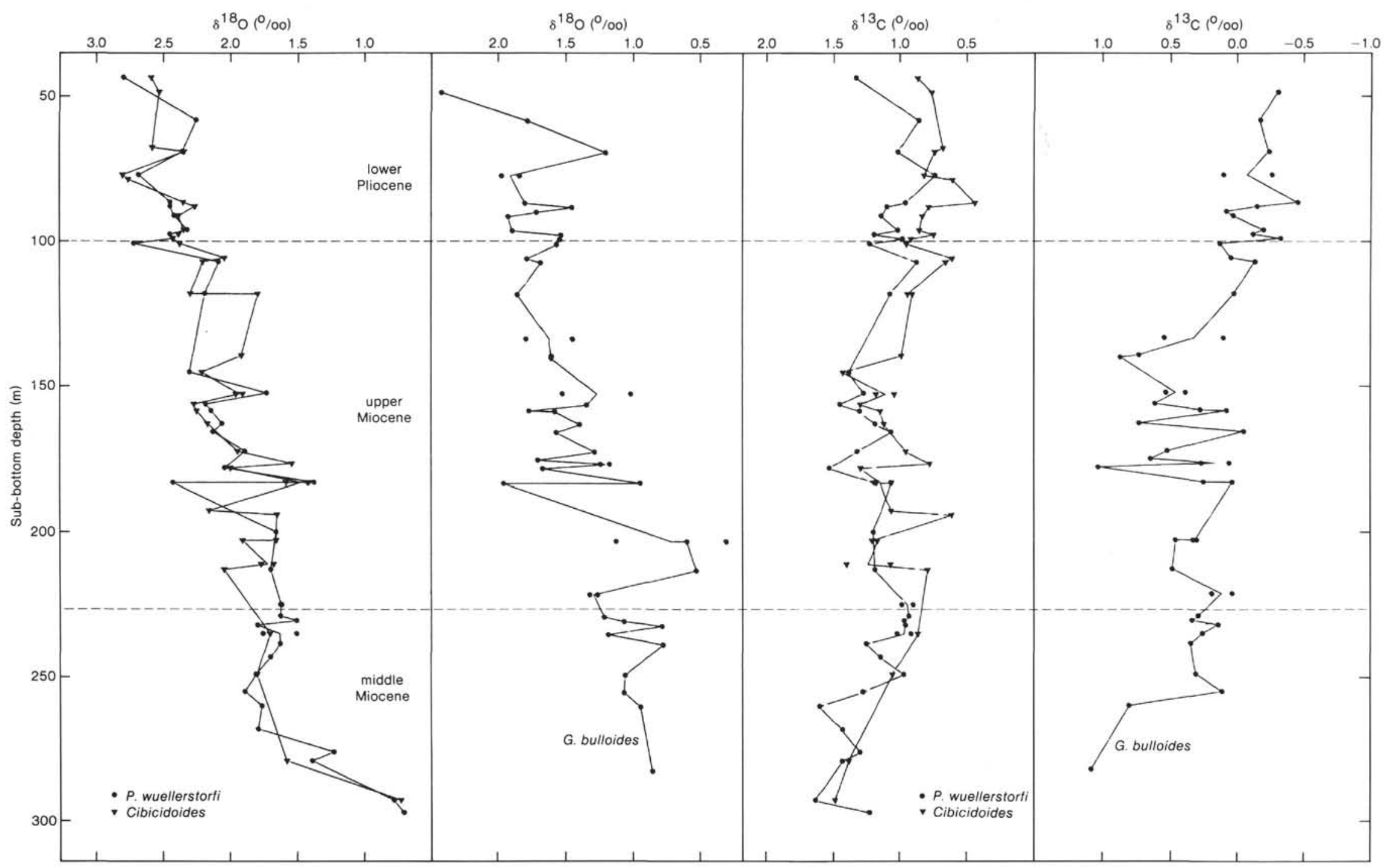

Figure 9. Stable-isotope results for Site 408. The long-term $\delta^{18} \mathrm{O}$ increase probably reflects ice volume increase in the middle Miocene and cooling surface and intermediate waters at this highlatitude $\left(63^{\circ} \mathrm{N}\right)$ location. Carbon isotope ratios in the upper Miocene decrease between $\sim 110$ and $140 \mathrm{~m}$, suggesting the $\delta^{13} \mathrm{C}$ shift at $\sim 6.2 \mathrm{Ma}$. Biostratigraphy at this site, however, is uncertain (see text). 


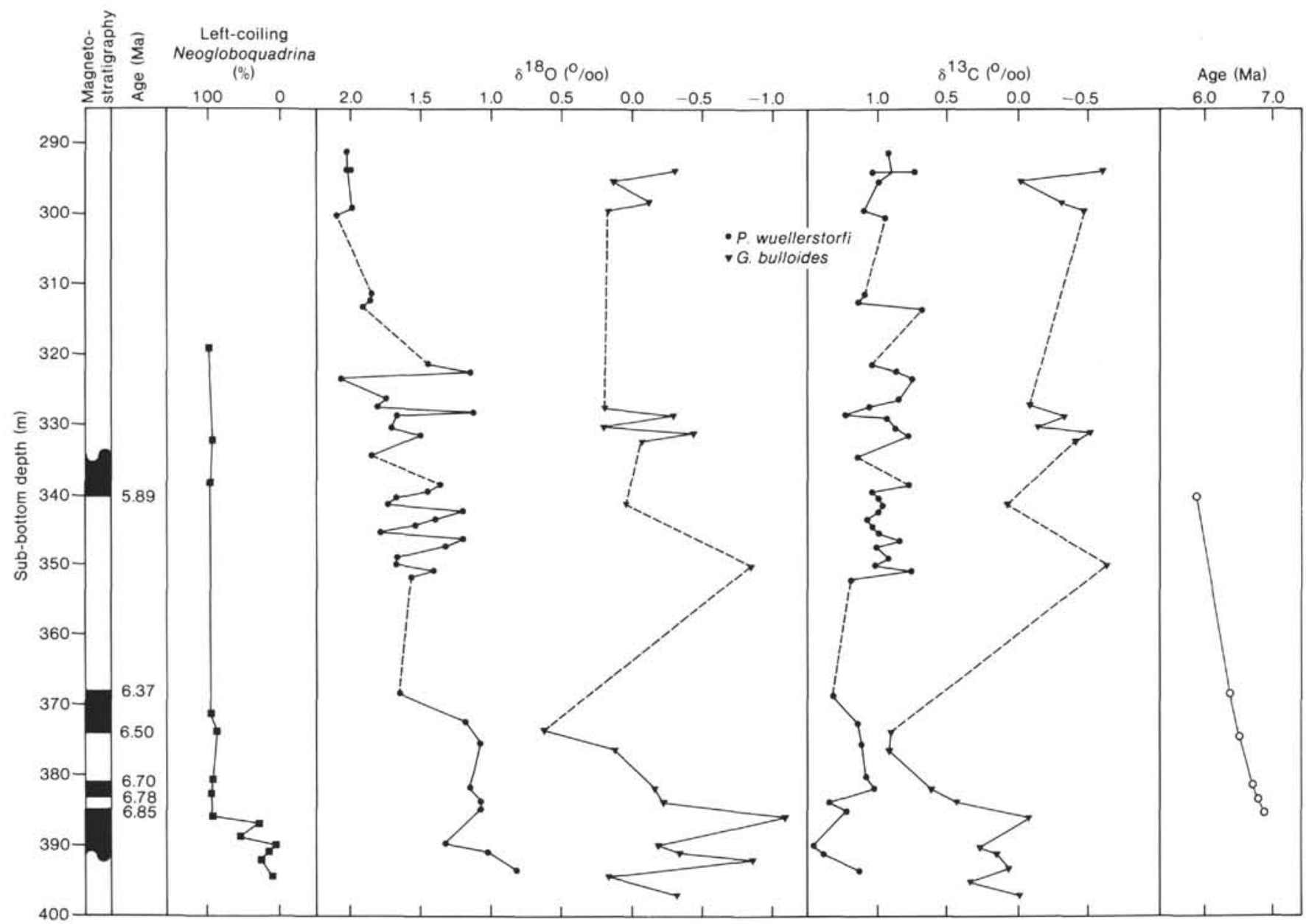

Figure 10. Stable-isotope results for Hole 611C. Dashed lines span intervals where there are gaps in core recovery or where there was an insufficient number of specimens for stable isotope analysis. Magnetostratigraphy from Clement and Robinson (this volume). The $\delta^{13} \mathrm{C}$ results are consistent with those for Hole 552A (Fig. 6), and show a maximum in $P$. wuellerstorfi $(\sim 1.5 \%$ ) coincident with the change in Neogloboquadrina coiling at $\sim 7 \mathrm{Ma}$, and a decrease in values at $\sim 6 \mathrm{Ma}$. Lowered $\delta^{18} \mathrm{O}$ values in benthic and planktonic foraminifers suggest diagenetic alteration.

above $\sim 295 \mathrm{~m}$. Peak $\delta^{13} \mathrm{C}$ values occur at $290 \mathrm{~m}\left(\delta^{13} \mathrm{C} P\right.$. wuellerstorf $i=1.5 \%$ ), coincident with the dominance of left coiling in Neogloboquadrina (Fig. 7). At Holes $552 \mathrm{~A}$ and $611 \mathrm{C}$, the coiling shift in Neogloboquadrina and the $\delta^{13} \mathrm{C}$ maximum of $P$. wuellerstorfi of $1.5 \%$ occur only at one level, dated at $\sim 7 \mathrm{Ma}$. It seems likely that the coincidence of these events in Hole 610E (occurring below the $\delta^{13} \mathrm{C}$ shift) is not due to chance and that they are correlatable between the three sites. This is inconsistent, however, with the nearby first appearance of Amaurolithus, unless there is a condensed interval just above $290 \mathrm{~m}$ sub-bottom.

\section{Site 334}

After spudding in and recovering one Pleistocene core on the west flank of the Mid-Atlantic Ridge, Leg 37 scientists washed down to $130 \mathrm{~m}$ and began coring about $100 \mathrm{~m}$ of upper Miocene foraminifer-bearing nannofossil ooze (Aumento, Melson, et al., 1977). Biostratigraphic studies indicate continuous sedimentation during the late Miocene, although no Pliocene sediment was recovered (Bukry, 1977). Since two species of Amaurolithus first appear between 140 and $150 \mathrm{~m}$, the level corresponding to $6 \mathrm{Ma}$ probably occurs above $140 \mathrm{~m}$ sub-bottom, but the $\delta^{13} \mathrm{C}$ shift is not evident at this site (Appendix). There may be too few samples analyzed from above 140 $\mathrm{m}$ to recognize a trend to lowered $\delta^{13} \mathrm{C}$.

\section{PALEOENVIRONMENTAL INTERPRETATION OF STABLE-ISOTOPE RESULTS}

\section{Late Miocene Oxygen Isotopes, Glaciation, and Sea Level}

Despite the success of oxygen isotope stratigraphy in Quaternary and upper Pliocene sediments, it has not yet proved applicable for upper Miocene sediments. Two reasons for this are the reduced amplitude of the late Miocene $\delta^{18} \mathrm{O}$ signal $(\sim 0.5 \%)$ and insufficiently detailed sampling to identify adequately oxygen isotope "events." Events of $\delta^{18} \mathrm{O}$ enrichment at Hole 552A (Fig. 5) may prove useful for correlation if they are seen at other locations with sufficiently detailed sampling. It must be established that ${ }^{18} \mathrm{O}$ events actually reflect ice volume fluctuations before correlations with sites that were sampled at larger intervals can be made with confidence.

The ice volume record of the late Miocene is of considerable interest to paleoceanographers. Ever since lat- 


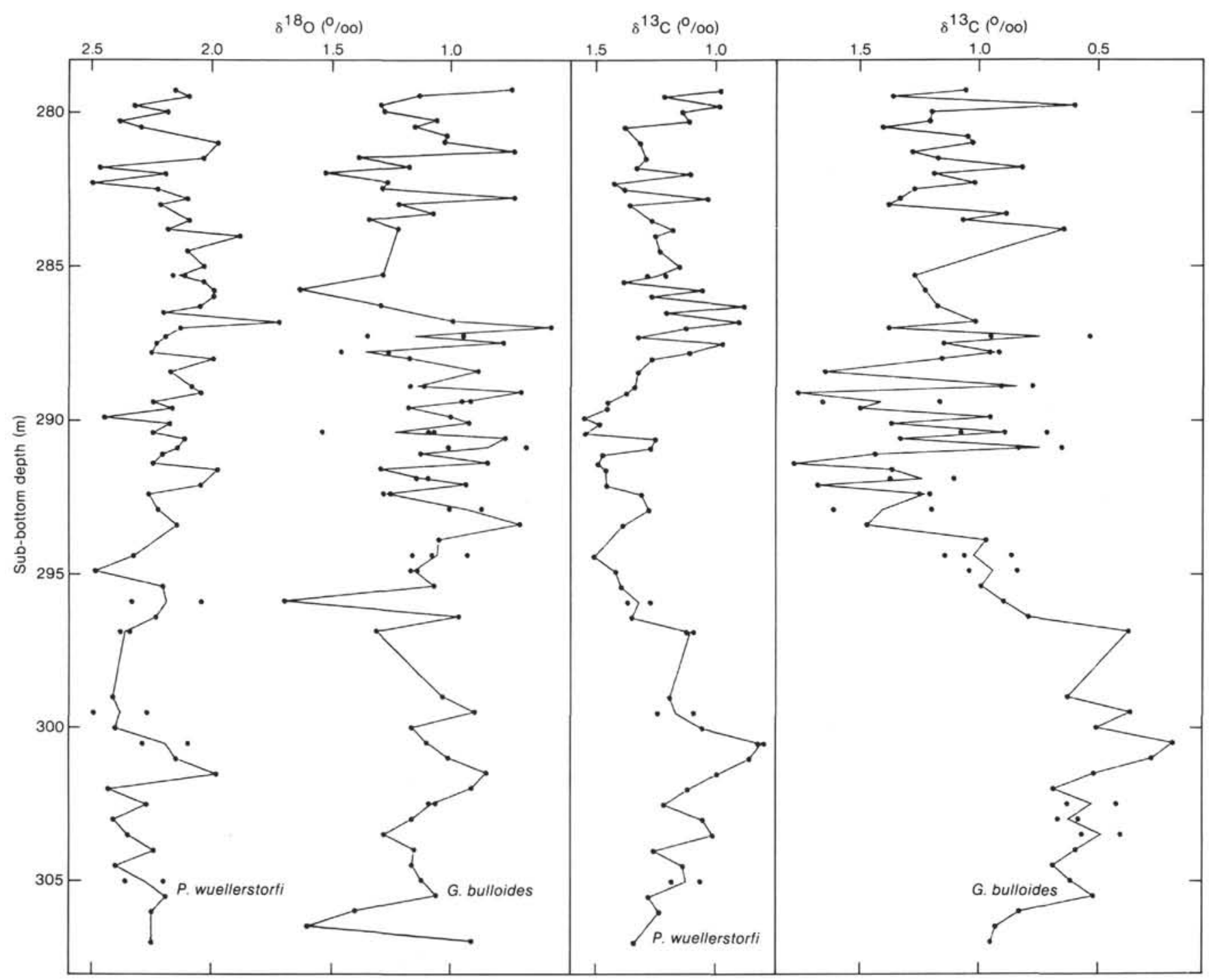

Figure 11. Stable-isotope results for Hole $610 \mathrm{E}$. As at Holes 552A (Fig. 6) and $611 \mathrm{C}$ (Fig. 10), $\delta^{13} \mathrm{C}$ of $P$. wuellerstorfi reaches $1.5 \%$ when the coiling of Neogloboquadrina changes. This observation, combined with the general ${ }^{13} \mathrm{C}$ enrichment in $P$. wuellerstorfi and $G$. bulloides, suggests that this interval of sediment corresponds to early Chron 6 and late Chron 7 (see Clement and Robinson, this volume).

est Miocene ice cap expansion in Antarctica was first hypothesized (Kennett, 1967), it has been regarded as a result of or a partial cause of the Messinian salinity crisis (compare Ryan et al., 1974 with Van Couvering et al., 1976; Adams et al., 1977 and Cita and Ryan, 1979). Various studies have interpreted oxygen isotope evidence as indicating major expansion of the Antarctic ice cap (Shackleton and Kennett, 1975a; Cita and Ryan, 1979; McKenzie et al., 1984; McKenzie and Oberhänsli, in press; among others). There are a few problems with these interpretations. First, most previous studies have presented too few data to resolve the true nature of late Miocene climatic variability. The upper Miocene oxygen isotope record at Hole 552A, for example (Fig. 5), has small excursions of a few tenths per mil, which form the background signal. One-point spikes of larger amplitude are not considered significant. Long-term trends are considered significant, however, as are multipoint peaks which appear in both the benthic and planktonic records. Co- variance of $\delta^{18} \mathrm{O}$ in benthic and planktonic foraminifers is taken as the best evidence of seawater compositional change, and hence changes in continental ice volume (Shackleton and Opdyke, 1973). Second, no oxygen isotope study has shown an ${ }^{18} \mathrm{O}$ enrichment in benthic foraminifers to be so large that there might have been more continental ice than today. Third, Mercer and Sutter (1982) argue that the latest Miocene glaciation was probably not restricted to the Southern Hemisphere.

No net change in $\delta^{18} \mathrm{O}$ is revealed by results from the interval 105 to $160 \mathrm{~m}$ at Hole 552A (Fig. 5). Increasing $\delta^{18} \mathrm{O}$ values in $G$. bulloides between $\sim 170$ and $165 \mathrm{~m}$ may reflect some of the ice volume increase associated with middle Miocene glaciation (Shackleton and Kennett, 1975b; Woodruff et al., 1981), but the lack of evidence for "stepwise" increases in $\delta^{18} \mathrm{O}$ higher in the section suggests no long-term continental ice storage event during the last $1.5 \mathrm{~m}$.y. of the late Miocene. There may have been ice growth events earlier in the late Miocene- 
for example, the inferred growth and grounding of the west Antarctica ice sheet (Ciesielski et al., 1982)-but the oxygen isotope evidence for this may be lost in the hiatuses, which are frequent below $\sim 152 \mathrm{~m}$ in Hole $552 \mathrm{~A}$.

At several levels in Hole 552A, $\delta^{18} \mathrm{O}$ of $G$. bulloides is significantly increased over background values $(\sim 106$, 119 , and $140 \mathrm{~m}$ ), and at other levels, variability within the background appears significant (e.g., between 113 and $118 \mathrm{~m}$ ). None of these levels fall within disturbed intervals at the tops of cores, so they are likely to reflect real temperature, salinity, or ice volume changes. Enrichment in ${ }^{18} \mathrm{O}$ in benthic foraminifers is also found at $\sim 106$ and $119 \mathrm{~m}$, but not at $140 \mathrm{~m}$. Covariance of the benthic and planktonic oxygen isotope records for the younger two events, dated at $\sim 5.0$ and $\sim 5.5 \mathrm{Ma}$ (Fig. 2), is good evidence of glacial maxima at these times, because the signal probably reflects a seawater compositional change. Further evidence in support of the interpretation of these samples as deposited during glacial intervals comes from the magnitude of ${ }^{18} \mathrm{O}$ enrichment in benthic foraminifers. The $\delta^{18} \mathrm{O}$ spike in $G$. bulloides at $\sim 140 \mathrm{~m}$ may simply reflect a pulse of surface water cooling.

Peak $\delta^{18} \mathrm{O}$ values of $\sim 3.0 \%$ at $\sim 106$ and $\sim 119 \mathrm{~m}$ sub-bottom are about $0.3 \%$ greater than data on late Holocene Cibicidoides and $P$. wuellerstorf $i$ in the North Atlantic (see, e.g., Boyle and Keigwin, 1985/1986). At Hole $552 \mathrm{~A}$ these $\delta^{18} \mathrm{O}$ peaks are $0.6 \%$ greater than background values of $\sim 2.4 \%$, which suggests that relative sea level at $\sim 5.0$ and $5.5 \mathrm{Ma}$ was $60 \mathrm{~m}$ lower than the late Miocene mean and only about $30 \mathrm{~m}$ lower than today.

The $\sim 5.0-\mathrm{Ma}$ glaciation at Hole 552A is represented over a $30-\mathrm{cm}$ interval, and the older event spans $60 \mathrm{~cm}$. Assuming a calculated sedimentation rate of $\sim 30 \mathrm{~m} /$ m.y. during the latest Miocene at Hole 552A (Fig. 2), we suggest that these glacial maxima lasted no longer than about 20,000 yrs. These brief events are comparable in duration to late Quaternary glacial maxima.

Brief $\delta^{18} \mathrm{O}$ maxima corresponding to about the same time also occur at other locations. At DSDP Site 590, in the southwest Pacific (Elmstrom and Kennett, 1986), glacial maxima are suggested to have occurred at $\sim 4.8$ to $4.9 \mathrm{Ma}$ and at $\sim 5.5 \mathrm{Ma}$, although direct correlation with Hole $552 \mathrm{~A}$ is difficult because of the smaller number of isotope analyses and the use of a time scale (Kennett, von der Borch, et al., 1986) different from that used in our study. Other recent isotope evidence comes from McKenzie and Oberhänsli (1985), who indicate a cooling phase in the South Atlantic (DSDP 519) from 6.1 to $5.7 \mathrm{Ma}$, followed by distinct cooling events of possible glacial origin between 5.7 and $6.57 \mathrm{Ma}$, and between 5.37 and $5.18 \mathrm{Ma}$. These isotope results are in general agreement with the interpretations of Mercer and Sutter (1982), based on their study of glacial till bounded by dated basalts, that Andean glaciation reached $47^{\circ} \mathrm{S}$ between 7 and 4.6 Ma. Lithologic studies of DSDP cores from high latitudes in the South Atlantic have shown that major zones of ice-rafting occurred between 5.57 and $5.43 \mathrm{Ma}$ and at 5.35 and $5.0 \mathrm{Ma}$ (Ciesielski and Weaver, 1983).

\section{Carbon Isotopes, Circulation Changes, and Messinian Effects}

Covariance in the $\delta^{13} \mathrm{C}$ of benthic and planktonic foraminiferal records suggests seawater compositional effects. The carbon isotope shift at $\sim 6 \mathrm{Ma}$ may be part of a low-frequency signal (with a period of $\sim 2 \mathrm{~m}$.y.) seen in both benthic and planktonic foraminifers (Fig. 6). This event is thought to reflect seawater compositional effects as well as changing circulation patterns, since it has been observed at many locations and its magnitude is greater in the Indo-Pacific region (Bender and Keigwin, 1979; Vincent et al., 1980). The smaller ${ }^{13} \mathrm{C}$ depletion in foraminifers from the North Atlantic, compared with those from the Pacific, has been taken as evidence for increased "basin-basin fractionation" due to enhanced production of North Atlantic Deep Water (NADW) (Keigwin, 1982). Carbon isotope ratios in benthic foraminifers from Hole 552A are greater than in those from Site 502 in the western Caribbean, for samples between $\sim 5.0$ and $6.0 \mathrm{Ma}$ (Keigwin, 1982). Thus, the geographic contrast in deepsea $\delta^{13} \mathrm{C}$ between the Atlantic and Pacific was probably greater than previously reported, and therefore so, probably, was the production of NADW (Keigwin, 1982).

Blanc and Duplessy (1982) concluded that deep-water formation in the North Atlantic stopped during Messinian time because benthic $\delta^{13} \mathrm{C}$ values became as low in the North Atlantic as in the North Pacific. They argue that there may have been no NADW when the Mediterranean basin was desiccated, because the flow of highsalinity water from the Mediterranean is thought to help contribute to the high density needed for convection and NADW formation in the northern North Atlantic today (Reid, 1979). Evidence for Blanc and Duplessy's (1982) argument came from analysis of $P$. wuellerstorfi $\left(\delta^{13} \mathrm{C}\right.$ $=0.38 \%$, PDB) from one uppermost Miocene sample of DSDP Site 116. It may be seen from Figure 6 and the Appendix that only one analysis of several hundred for nearby Hole $552 \mathrm{~A}$ has a $\delta^{13} \mathrm{C}$ value as low as that reported by Blanc and Duplessy (at $124.72 \mathrm{~m}, \delta^{13} \mathrm{C}=0.38 \%$ ). It would appear from carbon isotope evidence at Hole $552 \mathrm{~A}$ that in general North Atlantic deep circulation was unaffected by the Messinian "salinity crisis."

Various authors have suggested that the lowering in $\delta^{13} \mathrm{C}$ values at $\sim 6.2 \mathrm{Ma}$ occurred in response to lowered sea level caused by Antarctic glaciation (Vincent et al., 1980; Loutit and Keigwin, 1982), in a manner similar to that proposed by Broecker (1982) to explain upper Quaternary $\delta^{13} \mathrm{C}$ records. One problem with extending the hypothesis for the late Quaternary to the late Miocene is the absence of oxygen isotope evidence for a glaciation of long enough duration to cause a "permanent" shift in $\delta^{13} \mathrm{C}$ values. Miller and Fairbanks (1985) likewise observed that, for earlier times in the Cenozoic, low-frequency $\delta^{13} \mathrm{C}$ cycles were not tied to global sea-level changes. These authors suggest that low-frequency cycles in the $\delta^{13} \mathrm{C}$ of total $\mathrm{CO}_{2}$ must reflect changes in the $\delta^{13} \mathrm{C}$ of $\mathrm{HCO}_{3}^{-}$in rivers or in the ratio of carbonate carbon to organic carbon buried in sediment.

Covariance between benthic and planktonic foraminiferal $\delta^{13} \mathrm{C}$ at high frequencies (Fig. 6) has not been 
previously observed in the upper Miocene sediment record. In fact, high-frequency changes in $\delta^{13} \mathrm{C}$ have only recently been reported for upper Quaternary benthic foraminifers (Mix and Fairbanks, 1985; Keigwin and Boyle, 1985). Mix and Fairbanks (1985) report that $\delta^{13} \mathrm{C}$ in Pleistocene North Atlantic benthic foraminifers varies on a 41,000-yr. time scale, which they cite as evidence for deepsea circulation changes approximately in phase with changes in the obliquity of the earth's orbit. Keigwin and Boyle (1985) report 21,000-yr. cyclicity in $\delta^{13} \mathrm{C}$ of Atlantic and Pacific benthic foraminifers, which may result from orbital forcing of continental biomass through low-latitude precipitation. Neither study reports on variability of $\delta^{13} \mathrm{C}$ in planktonic foraminifers. Our observation of coherent variability in benthic and planktonic foraminiferal $\delta^{13} \mathrm{C}$ strongly suggests cyclic variability in the $\delta^{13} \mathrm{C}$ of total $\mathrm{CO}_{2}$. Within the interval of about 0.2 m.y. that we consider to be early Chron 5, there are apparently about 10 cycles in benthic and planktonic foraminiferal $\delta^{13} \mathrm{C}$, giving a periodicity close to $20,000 \mathrm{yr}$. If time scale "a" (Fig. 2) is proved to be correct, the sedimentation rate would be about half as large, and the period would be closer to 40,000 yrs. To understand the true nature of variability in $\delta^{13} \mathrm{C}$ at Hole $552 \mathrm{~A}$, we must await studies of more complete sections. Nevertheless, we speculate that variability in the earth's orbit during the latest Miocene affected the size of the continental biomass reservoir, which in turn affected the $\delta^{13} \mathrm{C}$ of total $\mathrm{CO}_{2}$.

\section{CONCLUSIONS}

The 70-m Miocene section of DSDP Hole 552A has been sampled for detailed biostratigraphic, magnetostratigraphic, and stable-isotope studies. Our results indicate that the stratigraphic section is complete from 104 to $152 \mathrm{~m}$ sub-bottom and spans an interval of nearly 1.5 m.y. (between $\sim 6.5$ and $\sim 5.0 \mathrm{Ma}$ ). An unconformity occurs at $\sim 6.5 \mathrm{Ma}$ in lower magnetostratigraphic Chronozone 6 and is recognized by nannofossil biostratigraphy. Stratigraphic gaps increase in frequency and duration below this level, hampering paleoenvironmental study. Datum levels from four fossil groups (calcareous nannofossils, planktonic foraminifers, diatoms, and silicoflagellates), which are thought to mark the Miocene/Pliocene boundary, cluster within a $10-\mathrm{m}$ interval, but the boundary cannot be located precisely. Coiling direction in Neogloboquadrina appears to be useful for correlation among DSDP sites in the North Atlantic. All species of Neogloboquadrina apparently changed their coiling preference from dominantly right to dominantly left in magnetostratigraphic Chronozone 7, at about $7 \mathrm{Ma}$. Coiling of larger specimens ( $>300 \mu \mathrm{m})$, mostly Neogloboquadrina atlantica, remained left throughout the late Miocene, but smaller specimens coiled randomly in sediment younger than $\sim 5.5 \mathrm{Ma}$. The right to left coiling shift occurred at the same time as a distinct maximum in $\delta^{13} \mathrm{C}$ of the benthic foraminifer $P$. wuellerstorfi in DSDP Holes 552A, 610E, and 611C.

Decreased carbon isotope values in benthic and planktonic foraminifers at $\sim 6.2 \mathrm{Ma}$ have proved a useful stratigraphic marker in the Indo-Pacific region and in the
South Atlantic. This study extends this usefulness to the North Atlantic Ocean and confirms the timing of the $\delta^{13} \mathrm{C}$ "shift" within the younger reversed interval of Chron 6 at Holes 552A and 611C. The carbon isotopic shift is seen in four of the six North Atlantic sites that we have considered; at Site 334 it may not be evident, owing to insufficient sampling, and at Hole 610E sediment of about 6-m.y. age was probably not cored.

Similar patterns of carbon isotope variability, with periods ranging from $10^{4}$ to $10^{6} \mathrm{yrs}$., are evident in benthic and planktonic foraminifers from Hole 552A. This suggests that most changes in $\delta^{13} \mathrm{C}$ at North Atlantic sites reflect variability in the $\delta^{13} \mathrm{C}$ of total $\mathrm{CO}_{2}$ in seawater rather than changes in deep-sea circulation. In particular, there is no carbon isotope evidence for a deepsea circulation change in the North Atlantic resulting from the Messinian "salinity crisis."

Covariance in benthic and planktonic foraminiferal $\delta^{18} \mathrm{O}$ is taken as evidence of variation in the extent of glaciation. Brief glacial events of less than 20,000-yr. duration occurred at $\sim 5.0$ and $\sim 5.5 \mathrm{Ma}$. These events probably lowered relative sea level by $60 \mathrm{~m}$. There is no evidence at DSDP Hole 552A for a major ice growth event at 6 to $7 \mathrm{Ma}$ that could have lowered sea level long enough to cause a "permanent" decrease in $\delta^{13} \mathrm{C}$. Other brief events, however, may have been missed by coarse sampling (every $50 \mathrm{~cm}$ ) of sediment older than about $6 \mathrm{Ma}$.

\section{ACKNOWLEDGMENTS}

This work could not have been produced without the technical support of many people. We are particularly grateful for help from C. E. Franks, D. Lafferty, D. Ostermann, M. Poag, A. Tricca, and A. Witter. Some samples were provided by R. Z. Poore and some were examined by J. Baldauf. Samples from Core 552A-30 were provided by D. Schnitker. S. Asquith and P. Weiss made it especially convenient to sample at the DSDP East Coast Repository. Helpful comments on the manuscript were provided by W. A. Berggren, L. H. Burckle, T. S. Loutit, J. A. McKenzie, and K. G. Miller. This research was supported by NSF Grants OCE 81-17590 and OCE 83-8893 to L.D.K, and OCE 83-00356 and OCE 84-00805 to DVK. This is WHOI contribution No. 6030 and LDGO Contribution No. 3922.

\section{REFERENCES}

Adams, C. G., Benson, R. H., Kidd, R. B., Ryan, W. B. F. and Wright, R. C., 1977. The Messinian salinity crisis and evidence of late Miocene eustatic changes in the world ocean. Nature, 269:383-386.

Aumento, F., Melson, W. G., et al., 1977. Init. Repts. DSDP, 37: Washington (U.S. Govt. Printing Office).

Backman, J., 1984. Cenozoic calcareous nannofossil biostratigraphy from the northeastern Atlantic Ocean-Deep Sea Drilling Project, Leg 81. In Roberts, D. G., Schnitker, D., et al., Init. Repts. DSDP, 81: Washington (U.S. Govt. Printing Office), 403-428.

Baldauf, J. G., 1984. Cenozoic diatom biostratigraphy and paleoceanography of the Rockall Plateau region, North Atlantic, Deep Sea Drilling Project, Leg. 81. In Roberts, D. G., Schnitker, D., et al., Init. Repts. DSDP, 81: Washington (U.S. Govt. Printing Office), 439-478.

Bandy, O. L., 1960. Geological significance of coiling ratios in the foraminifera Globigerina pachyderma (Ehrenberg). J. Paleontol., 34: 671-681.

Bender, M. L., and Keigwin, L. D., Jr., 1979. Speculations about the upper Miocéne change in abyssal Pacific dissolved bicarbonate $\delta^{13} \mathrm{C}$. Earth Planet. Sci. Lett., 45:383-393.

Berggren, W. A., 1972. Cenozoic biostratigraphy and paleobiogeography of the North Atlantic. In Laughton, A. S., Berggren, W. A., et al., Init. Repts. DSDP, 12: Washington (U.S. Govt. Printing Office), 965-1001. 
1977. Late Neogene planktonic foraminiferal biostratigraphy of the Rio Grande Rise (South Atlantic). Mar. Micropaleontol., 2:265-313.

Berggren, W. A., Kent, D. V., and Van Couvering, J. A., in press. Neogene geochronology and chronostratigraphy. In Snelling, N. J. (Ed.), Geochronology and the Geological Record. Geol. Soc. London. Mem.

Blanc, P.-L., and Duplessy, J.-C., 1982. The deep-water circulation during the Neogene and the impact of the Messinian salinity crisis. Deep-Sea Res., 29:1391-1414.

Boyle, E. A., and Keigwin, L. D., 1985/1986. Comparison of Atlantic and Pacific paleochemical records for the last 215,000 years: Changes in deep ocean circulation and chemical inventories. Earth Planet. Sci. Lett., 76:135-150.

Broecker, W. S., 1982. Ocean chemistry during glacial time. Geochim. Cosmochim. Acta, 46:1689-1705.

Bukry, D., 1973. Low-latitude coccolith biostratigraphic zonation. In Edgar, N. T., Saunders, J. B., et al., Init. Repts. DSDP, 15: Washington (U.S. Govt. Printing Office), 605-703.

1977. Coccolith and silicoflagellate stratigraphy, central North Atlantic Ocean, DSDP Leg 37. In Aumento, F., Melson, W. G., et al., Init. Repts. DSDP, 37: Washington (U.S. Govt. Printing Office), 927-927

1979. Coccolith and silicoflagellate stratigraphy, northern Mid-Atlantic Ridge and Reykjanes Ridge, Deep Sea Drilling Project Leg 49. In Luyendyk, B. P., Cann, J. R., et al., Init. Repts. DSDP, 49: Washington (U.S. Govt. Printing Office), 551-581.

, 1984. Cenozoic silicoflagellates from Rockall Plateau, Deep Sea Drilling Project, Leg 81. In Roberts, D. G., Schnitker, D., et al., Init. Repts. DSDP, 81: Washington (U.S. Govt. Printing Office), 547-563.

Ciesielski, P. F., Ledbetter, M. T., and Ellwood, B. B., 1982. The development of Antarctic glaciation and the Neogene paleoenvironment of the Maurice Ewing Bank. Mar. Geol., 46:1-51.

Ciesielski, P. F., and Weaver, F. M., 1983. Neogene and Quaternary paleoenvironmental history of Deep Sea Drilling Project Leg 71 sediments, southwest Atlantic Ocean. In Ludwig, W. J., Krasheninnikov, V. A., et al., Init. Repts. DSDP, 71: Washington (U.S. Govt. Printing Office), 461-477.

Cita, M. B., and Ryan, W. B. F., 1979. Late Neogene environmental evolution. In von Rad, U., Ryan, W. B. F., et al., Init. Repts. DSDP 47, Pt. 1: Washington (U.S. Govt. Printing Office), 447-459.

Elmstrom, K. M., and Kennett, J. P., 1986. Late Neogene paleoceanographic evolution of DSDP Site 590: southwest Pacific. In Kennett, J. P., von der Borch, C., et al., Init. Repts. DSDP, 90, Pt. 2: Washington (U.S. Govt. Printing Office), 1361-1381.

Emrich, K., Ehalt, D. H., and Vogel, J. C., 1970. Carbon isotope fractionation during the precipitation of calcium carbonate. Earth Planet. Sci. Lett., 8:363-371.

Foster, J. H., and Opdyke, N. D., 1970. Upper Miocene to Recent magnetic stratigraphy in deep-sea sediments. J. Geophys. Res., 75: 4465-4473.

Ganssen, G., 1981. Isotopic analysis of foraminifera shells: Interference from chemical treatment. Palaeogeogr., Palaeoclimatol., Palaeoecol., 33:271-276.

Gartner, S., 1973. Absolute chronology of the late Neogene calcareous nannofossil succession in the equatorial Pacific. Geol. Soc. Am. Bull., 84:2021-2034.

Graham, D. W., Corliss, B. H., Bender, M. L., and Keigwin, L. D., Jr., 1981. Carbon and oxygen isotopic disequilibria of recent deepsea benthic foraminifera. Mar. Micropaleontol., 6:483-497.

Haq, B. U., and Berggren, W. A., 1978. Late Neogene calcareous plankton biochronology of the Rio Grande Rise (South Atlantic Ocean). J. Paleontol., 52:1167-1194.

Haq, B. U., Worsley, T. R., Burckle, L. H., Douglas, R. G., Keigwin, L. D., Jr., et al., 1980. Late Miocene marine carbon-isotopic shift and synchroneity of some phytoplanktonic biostratigraphic events. Geology, 8:427-431.

Huddlestun, P., 1984. Planktonic foraminiferal biostratigraphy, Deep Sea Drilling Project Leg 81. In Roberts, D. G., Schnitker, D., et al., Init. Repts. DSDP, 81: Washington (U.S. Govt. Printing Office), 429-438.

Keigwin, L. D., Jr., 1979. Late Cenozoic stable isotope stratigraphy and paleoceanography of DSDP sites from the east equatorial and central North Pacific Ocean. Earth Planet. Sci. Lett., 45:361-382.
1982. Stable isotope stratigraphy and paleoceanography of Sites 502 and 503. In Prell, W. L., Gardner, J. V., et al., Init. Repts. $D S D P, 68$ : Washington (U.S. Govt. Printing Office), 445-453. 1984. Stable isotopic results on upper Miocene and lower Pliocene foraminifera from Hole 552A. In Roberts, D. G., Schnitker, D., et al., Init. Repts. DSDP, 81: Washington (U.S. Govt. Printing Office), 595-597.

Keigwin, L. D., and Boyle, E. A., 1985. Carbon isotopes in deep-sea benthic foraminifera: Precession and changes in low-latitude biomass. In Sundquist, E., and Broecker, W. S. (Eds.), The Carbon Cycle and Atmospheric $\mathrm{CO}_{2}:$ Natural Variations Archean to Present. Am. Geophys. Union Geophys. Monogr., 32:319-328.

Keigwin, L. D., Jr., and Shackleton, N. J., 1980. Uppermost Miocene carbon isotope stratigraphy of a piston core in the equatorial $\mathrm{Pa}$ cific. Nature, 284:613-614.

Kennett, J. P., 1967. Recognition and correlation of the Kapitean Stage (upper Miocene, New Zealand). New Zealand J. Geol. Geophys., 10:1051-1063.

Kennett, J. P., and Vella, P., 1975. Late Cenozoic planktonic foraminiferal and paleoceanography of DSDP Site 284 in the cool subtropical South Pacific. In Kennett, J. P., Houtz, R. E., et al., Init. Repts. DSDP, 29: Washington (U.S. Govt. Printing Office), 769 799.

Kennett, J. P., von der Borch, C., et al., 1986. Init. Repts. DSDP, 90, Pt. 1: Washington (U.S. Govt. Printing Office).

Klitgord, K. D., Huestis, S. P., Mudie, J. D., and Parker, R. L., 1975. An analysis of near-bottom magnetic anomalies: Sea-floor spreading and the magnetized layer. Geophys. J. R. Astron. Soc., 43: 387-424.

Kroopnick, P., 1980. The distribution of ${ }^{13} \mathrm{C}$ in the Atlantic Ocean. Earth Planet. Sci. Lett., 49:469-484.

Loutit, T. S., and Keigwin, L. D., Jr., 1982. Stable isotopic evidence for latest Miocene sea-level fall in the Mediterranean region. $\mathrm{Na}$ ture, 300:163-166.

Loutit, T., and Kennett, J. P., 1979. Application of carbon isotope stratigraphy to late Miocene shallow marine sediments, New Zealand. Science, 204:1196.

Luyendyk, B. P., Cann, J. R., et al., 1979. Init. Repts. DSDP, 49: Washington (U.S. Govt. Printing Office).

McKenzie, J. A., and Oberhänsli, H., 1985. Paleoceanographic expressions of the Messinian salinity crisis. In Hsü, K. J. and Weissert, H. S. (Eds.), South Atlantic Paleoceanography: Cambridge (Cambridge University Press), pp. 99-123.

McKenzie, J. A., Weissert, H. J., Poore, R. Z., Wright, R. C., Percival, S. F., Jr., et al., 1984. Paleoceanographic implications of stable isotope data from upper Miocene-lower Pliocene sediments from the southeast Atlantic (Deep Sea Drilling Project Site 519). In Hsü, K. J., La Brecque, J. L., et al., Init. Repts. DSDP, 73: Washington (U.S. Govt. Printing Office), 717-784.

Martini, E., 1971. Standard Tertiary and Quaternary calcareous nannoplankton zonation. In Farinacci, A. (Ed.), Proc. Second Planktonic Conf. (Rome, 1970) (Vol. 2): Rome (Ed. Tecnoscienza), 723795.

Matthews, R. K., Curry, W. B., Lohmann, K. C., Sommer, M. A., and Poore, R. Z., 1980. Late Miocene paleo-oceanography of the Atlantic: Oxygen isotope data on planktonic and benthic foraminifera. Nature, 283:555-557.

Mercer, J. H., and Sutter, J. F., 1982. Late Miocene-earliest Pliocene glaciation in southern Argentina: Implications for global ice-sheet history. Palaeogeogr., Palaeoclimatol., Palaeoecol., 38:185-206.

Miller, K. G., and Fairbanks, R. G., 1985. Oligocene and Miocene carbon isotope cycles and abyssal circulation changes. In Sundquist, E. T., and Broecker, W. (Eds.), Natural Variations in Carbon Dioxide and the Carbon Cycle. Am. Geophys. Union Geophys. Monogr., 32:469-486.

Mix, A. C., and Fairbanks, R. G., 1985. North Atlantic surface-ocean control of Pleistocene deep-ocean circulation. Earth Planet. Sci. Lett., 73:231-243.

Müller, C., 1974. Calcareous nannoplankton, Leg 25 (western Indian Ocean). In Simpson, E. S. W., Schlich, R., et al., Init. Repts. DSDP, 25: Washington (U.S. Govt. Printing Office), 579-633.

Okada, M., and Bukry, D., 1980. Supplementary modirication and introduction of code numbers on the low-latitude coccolith biostratigraphic zonation (Bukry, 1973 and 1975). Mar. Micropaleontol., 5:321-375. 
Poore, R. Z., 1979. Oligocene through Quaternary planktonic foraminiferal biostratigraphy of the North Atlantic: DSDP Leg 49. In Luyendyk, B. P., Cann, J. R., et al, Init. Repts. DSDP, 49: Washington (U.S. Govt. Printing Office), 447-517.

, 1981a. Late Miocene biogeography and paleoclimatology of the central North Atlantic. Mar. Micropaleontol., 6:599-616.

, 1981b. Temporal and spatial distribution of ice-rafted mineral grains in Pliocene sediments of the North Atlantic: Implications for late Cenozoic climate history. In Warme, J. E., Douglas, R. G., and Winterer, E. L. (Eds.), The Deep Sea Drilling Project: A Decade of Progress. Soc. Econ. Paleontol. Mineral. Spec. Publ., 32:505-515.

Reid, J. L., 1979. On the contribution of the Mediterranean Sea outflow to the Norwegian-Greenland Sea. Deep-Sea Res., 26A:11991223.

Roberts, D. G., Schnitker, D., et al., 1984. Init. Repts. DSDP, 81: Washington (U.S. Govt. Printing Office).

Ryan, W. B. F., Cita, M. B., and Rawson, M. D., Burckle, L. H., and Saito, I., 1974. A paleomagnetic assignment of Neogene stage boundaries and the development of isochronous datum planes between the Mediterranean, the Pacific and Indian oceans in order to investigate the response of the world ocean to the Mediterranean "salinity crisis." Riv. Ital. Paleontol., 80:631-688.

Ryan, W. B. F., Hsü, K., et al., 1973. Init. Repts. DSDP, 13: Washington (U.S. Govt. Printing Office).

Saito, T., Burckle, L. H., and Hays, J. L., 1975. Late Miocene to Pleistocene biostratigraphy of equatorial Pacific sediments. In Saito, T., and Burckle, L. (Eds.), Late Neogene Epoch Boundaries: New York (Micropaleontol. Press), pp. 226-244.

Schlanger, S. O., and Douglas, R. G., 1974. The pelagic ooze-chalklimestone transition and its implication for marine stratigraphy. In Hsü, K. J., and Jenkyns, H. (Eds.), Pelagic Sediments: On Land and Under the Sea. Int. Assoc. Sedimentol. Spec. Publ., 1:117-148.

Schnitker, D., 1984. High resolution records of benthic foraminifers in the late Neogene of the northeastern North Atlantic. In Roberts, D. G., Schnitker, D., et al., Init. Repts. DSDP, 81: Washington (U.S. Govt. Printing Office), 611-622.

Shackleton, N. J., Backman, J., Zimmerman, H., Kent, D. V., Hall, M. A., et al., 1984. Oxygen isotope calibration of the onset of icerafting and history of glaciation in the North Atlantic region. Nature, 307:620-623.

Shackleton, N. J., and Cita, M. B., 1979. Oxygen and carbon isotope stratigraphy of benthic foraminifers at Site 397: Detailed history of climatic change during the late Neogene. In von Rad, U., Ryan, W.
B. F., et al., Init. Repts. DSDP, 47, Pt. 1: Washington (U.S. Govt. Printing Office), 422-445.

Shackleton, N. J., Hall, M. A., and Boersma, A., 1984. Oxygen and carbon isotope data from Leg 74 foraminifers. In Moore, T. C., Jr., Rabinowitz, P. D., et al., Init. Repts. DSDP, 74: Washington (U.S. Govt. Printing Office), 599-611.

Shackleton, N. J., and Kennett, J. P., 1975a. Late Cenozoic oxygen and carbon isotopic changes at DSDP Site 284: Implications for glacial history of the Northern Hemisphere and Antarctica. In Kennett, J. P., Houtz, R. E., et al., Init. Repts. DSDP, 29: Washington (U.S. Govt. Printing Office), 801-807.

1975b. Paleotemperature history of the Cenozoic and the initiation of Antarctic glaciation: Oxygen and carbon isotope analyses in DSDP Sites 277, 279, 281. In Kennett, J. P., Houtz, R. E. et al., Init. Repts. DSDP, 29: Washington (U.S. Govt. Printing Office), 743-756.

Shackleton, N. J., and Opdyke, N. D., 1973. Oxygen isotope and paleomagnetic stratigraphy of equatorial Pacific Core V28-238: Oxygen isotope temperatures and ice volumes on a $10^{5}$ year and $10^{6}$ year scale. Quat. Res., 3:39-55.

Steinmetz, J. C., 1979. Calcareous nannofossils from the North Atlantic Ocean, Leg 49 DSDP. In Luyendyk, B. P., Cann, J. R., et al., Init. Repts. DSDP, 49: Washington (U.S. Govt. Printing Office), 519-531.

Van Couvering, J. A., Berggren, W. A., Drake, R. E., Aguirre, E., and Curtis, G. N., 1976. The terminal Miocene event. Mar. Micropaleontol., 1:263-286.

Vergnaud Grazzini, C., Pierre, C. and Létolle, R., 1978. Paleoenvironment of the northeast Atlantic during the Cenozoic: Oxygen and carbon isotope analyses at DSDP Sites 398, 400A and 401. Oceanol. Acta, 1:381-390.

Vincent, E., Killingley, J. S., and Berger, W. H., 1980. The magnetic Epoch-6 carbon shift: A change in the ocean's ${ }^{13} \mathrm{C} /{ }^{13} \mathrm{C}$ ratio 6.2 million years ago. Mar. Micropaleontol., 5:185-203.

Westberg-Smith, M. J., and Riedel, W. R., 1984. Radiolarians from the western margin of the Rockall Plateau: DSDP Leg 81. In Roberts, D. G., Schnitker, D., et al., Init. Repts. DSDP, 81: Washington (U.S. Govt. Printing Office), 479-501.

Woodruff, F., Savin, S. M., and Douglas, R. G., 1981. Miocene stable isotope record: A detailed deep Pacific Ocean study and its paleoclimatic implications. Science, 212:665-668.

Date of Initial Receipt: 15 April 1985

Date of Acceptance: 9 October 1985 
APPENDIX

Stable-Isotope Results (\%0 PDB) for Sites 334, 408, and 410 and Holes 552A, 610E, and 611C.

\begin{tabular}{|c|c|c|c|c|}
\hline $\begin{array}{c}\text { Sample } \\
\text { depth (m) }\end{array}$ & $\delta^{18} 0$ & $\delta^{13} \mathrm{C}$ & $\begin{array}{l}\text { Sample } \\
\text { depth }(m)\end{array}$ & $\delta^{18} 0$ \\
\hline
\end{tabular}

Site 334

P. wuellerstorfi

$\begin{array}{lll}130.52 & 1.80 & 1.42 \\ 133.53 & 2.29 & 1.21 \\ 134.96 & 2.25 & 1.24 \\ 136.52 & 2.23 & 1.07 \\ 138.08 & 2.37 & 0.86 \\ 140.00 & 2.29 & 1.23 \\ 141.52 & 2.15 & 0.71 \\ 159.02 & 1.97 & 0.89 \\ 160.51 & 2.05 & 1.52 \\ 162.08 & 1.97 & 1.17 \\ 163.50 & 2.27 & 1.27 \\ 169.98 & 2.33 & 1.15 \\ 198.50 & 1.96 & 1.51 \\ 206.77 & 1.84 & 1.01 \\ 209.54 & 1.97 & 1.24 \\ 211.04 & 2.02 & 1.56 \\ 217.52 & 1.94 & 1.49 \\ 220.52 & 2.49 & 1.59 \\ 227.02 & 2.07 & 1.60 \\ 236.52 & 1.93 & 1.41\end{array}$

\section{G. quadrilobatus}

$\begin{array}{lrl}130.52 & 0.06 & 1.42 \\ 132.08 & 0.40 & 1.21 \\ 133.53 & 0.06 & 1.89 \\ 138.08 & 0.41 & 1.83 \\ 140.00 & 0.14 & 1.67 \\ 141.52 & -0.11 & 1.69 \\ 149.61 & -0.45 & 2.01 \\ 159.02 & -0.17 & 2.13 \\ 160.51 & -0.25 & 2.37 \\ 162.08 & -0.31 & 2.25 \\ 163.50 & 0.03 & 2.15 \\ 168.50 & -0.41 & 2.28 \\ 169.98 & -0.04 & 1.97 \\ 178.03 & 0.03 & 1.95 \\ 198.50 & -0.44 & 2.40 \\ 201.54 & -0.40 & 1.71 \\ 206.77 & -0.80 & 2.56 \\ 209.54 & -0.14 & 1.93 \\ 211.04 & 0.10 & 2.86 \\ 217.52 & -0.10 & 1.74 \\ 220.52 & -0.58 & 2.62 \\ 227.02 & -0.22 & 2.39 \\ 236.52 & -0.08 & 1.89 \\ 239.56 & 0.42 & 2.37\end{array}$

Cibicidoides spp.

$\begin{array}{lll}132.08 & 2.33 & 1.13 \\ 134.96 & 2.37 & 1.11 \\ 168.50 & 2.29 & 1.21 \\ 188.98 & 1.97 & 1.33 \\ 201.54 & 1.60 & 1.13\end{array}$

\begin{tabular}{|c|c|c|c|c|c|}
\hline & & & & & \\
\hline & & & 225.00 & 1.61 & 0.98 \\
\hline & ulloio & & 225.00 & 1.62 & 0.90 \\
\hline & & & 228.94 & 1.62 & 0.93 \\
\hline 130.52 & 1.21 & 0.30 & 230.50 & 1.50 & 0.96 \\
\hline 133.53 & 0.65 & 0.17 & 232.06 & 1.79 & 0.95 \\
\hline 134.96 & 1.07 & 0.32 & 235.00 & 1.50 & 1.02 \\
\hline 136.52 & 0.94 & 0.23 & 235.00 & 1.75 & 0.91 \\
\hline 138.08 & 1.17 & 0.29 & 238.47 & 1.62 & 1.25 \\
\hline 140.00 & 0.97 & 0.40 & 243.04 & 1.69 & 1.14 \\
\hline 141.52 & 0.74 & 0.22 & 249.00 & 1.80 & 0.9 \\
\hline
\end{tabular}

Appendix (continued).

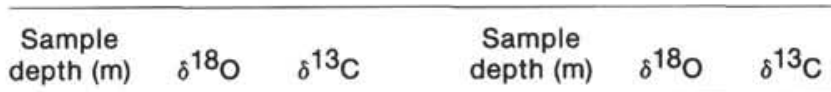

Site 408 (Cont.)

P. wuellerstorfi (Cont.)

\begin{tabular}{lll}
255.02 & 1.88 & 1.27 \\
260.00 & 1.76 & 1.60 \\
268.00 & 1.79 & 1.42 \\
275.82 & 1.22 & 1.29 \\
278.93 & 1.39 & 1.43 \\
292.35 & 0.78 & 1.63 \\
296.62 & 0.70 & 1.23 \\
\multicolumn{3}{c}{ Cibicidoides spp. }
\end{tabular}

\begin{tabular}{rrrrrr}
255.02 & 1.88 & 1.27 & 99.00 & 1.55 & -0.32 \\
260.00 & 1.76 & 1.60 & 100.76 & 1.57 & 0.13 \\
268.00 & 1.79 & 1.42 & 105.66 & 1.79 & 0.05 \\
275.82 & 1.22 & 1.29 & 107.00 & 1.69 & -0.13 \\
278.93 & 1.39 & 1.43 & 117.98 & 1.86 & 0.02 \\
292.35 & 0.78 & 1.63 & 133.30 & 1.45 & 0.10 \\
296.62 & 0.70 & 1.23 & 133.30 & 1.80 & 0.54 \\
\multicolumn{1}{c}{ Cibicidoides spp. } & 139.30 & 1.61 & 0.72 \\
& & & 140.06 & 1.61 & 0.86 \\
43.52 & 2.59 & 0.86 & 152.20 & 1.01 & 0.38 \\
48.50 & 2.53 & 0.76 & 152.20 & 1.53 & 0.52 \\
67.60 & 2.58 & 0.67 & 156.04 & 1.35 & 0.61 \\
69.00 & 2.34 & 0.73 & 158.10 & 1.78 & 0.27 \\
77.04 & 2.80 & 0.81 & 158.35 & 1.58 & 0.07 \\
78.56 & 2.76 & 0.60 & 162.75 & 1.40 & 0.72 \\
86.47 & 2.35 & 0.43 & 165.55 & 1.57 & -0.05 \\
87.92 & 2.26 & 0.78 & 172.26 & 1.29 & 0.51 \\
91.10 & 2.38 & 0.83 & 175.04 & 1.71 & 0.64 \\
96.02 & 2.34 & 0.85 & 176.48 & 1.24 & 0.05 \\
97.54 & 2.38 & 0.74 & 176.48 & 1.17 & 0.26 \\
99.00 & 2.42 & 0.91 & 178.04 & 1.67 & 1.02 \\
100.76 & 2.37 & 0.94 & 182.98 & 0.94 & 0.25 \\
105.66 & 2.04 & 0.60 & 183.08 & 1.96 & 0.03 \\
107.00 & 2.20 & 0.65 & 202.82 & 0.30 & 0.32 \\
117.98 & 2.29 & 0.94 & 202.82 & 1.12 & 0.29 \\
118.08 & 1.79 & 0.90 & 202.86 & 0.59 & 0.45 \\
139.30 & 1.91 & 0.98 & 212.88 & 0.52 & 0.47 \\
145.05 & 2.21 & 1.42 & 221.30 & 1.26 & 0.18 \\
152.50 & 1.95 & 1.17 & 221.30 & 1.32 & 0.02 \\
152.50 & 1.90 & 1.04 & 228.94 & 1.21 & 0.28 \\
156.04 & 2.27 & 1.29 & 230.50 & 1.06 & 0.33 \\
158.35 & 2.24 & 1.14 & 232.06 & 0.78 & 0.13 \\
162.75 & 2.16 & 1.11 & 235.00 & 1.18 & 0.25 \\
172.26 & 1.94 & 0.95 & 238.47 & 0.77 & 0.34 \\
176.48 & 1.54 & 0.77 & 249.00 & 1.05 & 0.29 \\
178.04 & 2.00 & 1.29 & 255.02 & 1.06 & 0.10 \\
182.98 & 1.41 & 1.17 & 260.00 & 0.94 & 0.79 \\
18.98 & 1.42 & 1.19 & 281.98 & 0.85 & 1.07
\end{tabular}

$\begin{array}{lll}182.98 & 1.42 & 1.19\end{array}$

$\begin{array}{lll}182.98 & 1.58 & 1.06\end{array}$

$192.60 \quad 2.15 \quad 1.06$

$194.00 \quad 1.65 \quad 0.61$

$202.82 \quad 1.65 \quad 1.20$

$202.86 \quad 1.90 \quad 1.16$

$\begin{array}{lll}210.99 & 1.77 & 1.39\end{array}$

$\begin{array}{lll}210.99 & 1.67 & 1.06 \\ 212.88 & 2.04 & 0.79\end{array}$

$\begin{array}{lll}212.88 & 2.04 & 0.79 \\ 235.00 & 1.70 & 0.86\end{array}$

$\begin{array}{lll}249.00 & 1.79 & 1.05\end{array}$

$\begin{array}{lll}278.93 & 1.58 & 1.38\end{array}$

292.35

$0.72 \quad 1.48$

Site 410

\section{P. wuellerstorfi}

$\begin{array}{rrr}97.29 & 2.65 & 0.91 \\ 101.67 & 2.59 & 0.79 \\ 126.30 & 3.13 & 0.31 \\ 147.50 & 2.55 & 0.95 \\ 162.25 & 2.09 & 1.05 \\ 175.10 & 2.39 & 1.03 \\ 181.10 & 2.24 & 0.80 \\ 181.80 & 2.24 & 0.74 \\ 188.50 & 1.93 & 0.53 \\ 190.56 & 2.18 & 0.83 \\ 194.10 & 2.16 & 0.90 \\ 201.20 & 2.13 & 0.63 \\ 204.00 & 1.89 & 0.66 \\ 209.64 & 1.95 & 0.93 \\ 212.68 & 2.04 & 1.33 \\ 214.03 & 1.93 & 1.16 \\ 215.13 & 2.03 & 1.28 \\ 219.26 & 1.83 & 1.08 \\ 220.48 & 1.71 & 1.36 \\ 221.20 & 2.21 & 1.34 \\ 225.04 & 2.11 & 1.07 \\ 225.77 & 1.56 & 1.35\end{array}$


Appendix (continued).

\begin{tabular}{cccccc}
\hline $\begin{array}{c}\text { Sample } \\
\text { depth }(\mathrm{m})\end{array}$ & $\delta^{18} \mathrm{O}$ & $\delta^{13} \mathrm{C}$ & $\begin{array}{c}\text { Sample } \\
\text { depth }(\mathrm{m})\end{array}$ & $\delta^{18} \mathrm{O}$ & $\delta^{13} \mathrm{C}$
\end{tabular}

Site 410 (Cont.)

P. wuellerstorfi (Cont.)

$\begin{array}{lll}226.52 & 1.96 & 1.20 \\ 227.00 & 1.96 & 1.05 \\ 229.66 & 1.94 & 1.27 \\ 229.84 & 1.76 & 1.32 \\ 231.47 & 1.67 & 1.36 \\ 233.00 & 1.86 & 1.39 \\ 233.42 & 2.50 & 1.48 \\ 234.16 & 1.67 & 1.45 \\ 236.50 & 2.27 & 1.40 \\ 238.00 & 2.18 & 1.69 \\ 239.40 & 1.89 & 1.41 \\ 246.21 & 2.78 & 1.43 \\ 249.00 & 2.02 & 1.47 \\ 257.00 & 2.17 & 1.19 \\ 266.50 & 2.01 & 1.40 \\ 270.10 & 1.86 & 1.41 \\ 296.90 & 1.93 & 0.98 \\ 313.70 & 1.82 & 1.40 \\ 325.40 & 1.89 & 1.41\end{array}$

Cibicidoides spp.

$\begin{array}{lll}131.13 & 2.49 & 1.04 \\ 134.55 & 2.38 & 0.81 \\ 146.74 & 2.48 & 1.04 \\ 159.00 & 1.77 & 0.82 \\ 181.10 & 2.14 & 0.33 \\ 225.77 & 1.77 & 1.42 \\ 226.52 & 1.74 & 1.01 \\ 231.47 & 1.94 & 1.32 \\ 232.71 & 1.79 & 1.32 \\ 233.00 & 1.87 & 1.42 \\ 234.16 & 1.80 & 1.39 \\ 249.00 & 2.07 & 1.31 \\ 266.50 & 2.07 & 1.38 \\ 270.10 & 2.15 & 1.38 \\ 282.00 & 1.82 & 1.28 \\ 296.90 & 2.02 & 0.98\end{array}$

G. bulloides

$\begin{array}{rrrrrr}93.41 & 0.70 & -0.92 & 249.00 & 0.83 & 0.75 \\ 97.29 & 1.12 & -0.37 & 257.00 & 0.48 & 0.64 \\ 101.67 & 0.78 & -1.12 & 266.50 & 0.81 & 0.55 \\ 112.26 & 0.64 & -0.78 & 270.10 & 0.86 & 0.61 \\ 124.33 & 0.77 & -0.89 & 275.60 & 0.82 & 0.57 \\ 125.50 & 1.39 & -0.72 & 279.00 & 0.76 & 1.10 \\ 126.30 & 1.25 & -0.44 & 282.00 & 0.85 & 0.75 \\ 128.36 & 0.70 & -0.21 & 294.78 & 0.49 & 1.25 \\ 131.13 & 0.84 & 0.91 & 296.90 & 1.04 & 0.45 \\ 132.68 & 1.01 & -0.55 & 313.70 & 0.83 & 0.84 \\ 134.55 & 1.01 & 0.09 & 325.40 & 0.77 & 0.84 \\ 136.17 & 0.94 & -0.24 & 325.40 & 0.72 & 0.65 \\ 137.10 & 1.23 & -0.20 & & & \\ 138.75 & 0.96 & -0.18 & \text { Hole } 552 A & & \\ 145.96 & 0.97 & -0.25 & & & \\ 146.74 & 0.90 & -0.24 & & \text { P. wuellerstorfi } \\ 147.50 & 1.38 & 0.48 & & & \\ 149.00 & 1.16 & 0.12 & 104.22 & 2.54 & 1.32 \\ 159.00 & 0.85 & 0.14 & 104.30 & 2.36 & 0.98 \\ 160.43 & 1.69 & 0.13 & 104.40 & 2.37 & 1.18 \\ 162.25 & 1.07 & 0.33 & 104.49 & 2.19 & 0.98 \\ 166.44 & 0.97 & 0.38 & 104.60 & 2.38 & 1.25 \\ 170.70 & 1.12 & 0.63 & 104.70 & 2.28 & 0.91 \\ 172.91 & 0.86 & -0.16 & 104.80 & 2.21 & 0.82\end{array}$

Appendix (continued).

\begin{tabular}{llllll}
\hline $\begin{array}{c}\text { Sample } \\
\text { depth }(\mathrm{m})\end{array}$ & $\delta^{18} \mathrm{O}$ & $\delta^{13} \mathrm{C}$ & $\begin{array}{c}\text { Sample } \\
\text { depth }(\mathrm{m})\end{array}$ & $\delta^{18} \mathrm{O}$ & $\delta^{13} \mathrm{C}$ \\
\hline
\end{tabular}

Hole 552A (Cont.)

P. wuellerstorfi (Cont.)

\begin{tabular}{|c|c|c|c|c|c|}
\hline 105.10 & 2.70 & 1.02 & 112.01 & 2.34 & 0.95 \\
\hline 105.20 & 2.35 & 0.92 & 112.11 & 2.59 & 1.17 \\
\hline 105.40 & 2.31 & 1.42 & 112.11 & 2.26 & 1.21 \\
\hline 105.50 & 2.46 & 1.39 & 112.20 & 2.44 & 0.96 \\
\hline 105.69 & 2.59 & 1.36 & 112.30 & 2.40 & 1.03 \\
\hline 105.86 & 2.22 & 1.02 & 112.41 & 2.28 & 1.15 \\
\hline 105.96 & 2.64 & 1.13 & 112.56 & 2.45 & 0.93 \\
\hline 106.02 & 2.84 & 0.90 & 112.60 & 2.46 & 0.98 \\
\hline 106.17 & 3.10 & 0.75 & 112.60 & 2.34 & 0.97 \\
\hline 106.23 & 2.67 & 0.92 & 112.70 & 2.55 & 1.07 \\
\hline 106.33 & 2.66 & 0.86 & 112.81 & 2.61 & 1.09 \\
\hline 106.50 & 2.37 & 0.92 & 112.90 & 2.49 & 1.12 \\
\hline 106.60 & 2.36 & 0.97 & 113.00 & 2.69 & 1.02 \\
\hline 106.70 & 2.74 & 0.79 & 113.70 & 2.57 & 0.94 \\
\hline 106.90 & 2.41 & 1.18 & 113.70 & 2.42 & 0.85 \\
\hline 107.00 & 2.60 & 1.32 & 113.78 & 2.64 & 1.12 \\
\hline 107.09 & 2.60 & 1.28 & 113.78 & 2.44 & 0.95 \\
\hline 107.20 & 2.19 & 0.87 & 113.78 & 2.33 & 0.95 \\
\hline 107.30 & 2.09 & 0.99 & 113.93 & 2.44 & 1.01 \\
\hline 107.40 & 2.31 & 0.95 & 114.08 & 2.71 & 1.03 \\
\hline 107.52 & 2.33 & 0.86 & 114.20 & 2.77 & 1.13 \\
\hline 107.61 & 2.23 & 1.04 & 114.29 & 2.56 & 0.94 \\
\hline 107.70 & 2.06 & 0.89 & 114.40 & 2.51 & 1.06 \\
\hline 107.80 & 2.27 & 0.81 & 114.55 & 2.61 & 1.11 \\
\hline 107.91 & 2.56 & 0.94 & 114.68 & 2.49 & 1.22 \\
\hline 108.03 & 2.39 & 0.65 & 114.78 & 2.28 & 0.96 \\
\hline 108.11 & 2.27 & 0.87 & 114.88 & 2.37 & 1.13 \\
\hline 108.20 & 2.41 & 0.78 & 114.94 & 2.48 & 0.76 \\
\hline 108.30 & 2.19 & 1.14 & 114.98 & 2.52 & 1.04 \\
\hline 108.40 & 2.18 & 0.96 & 115.10 & 2.39 & 1.05 \\
\hline 108.50 & 2.39 & 0.84 & 115.20 & 2.44 & 0.96 \\
\hline 108.60 & 2.26 & 1.18 & 115.52 & 2.41 & 0.92 \\
\hline 108.70 & 2.47 & 0.87 & 115.60 & 2.30 & 1.06 \\
\hline 108.80 & 2.33 & 0.96 & 115.94 & 2.39 & 1.18 \\
\hline 108.90 & 2.48 & 1.11 & 116.11 & 2.18 & 1.16 \\
\hline 109.10 & 2.58 & 1.15 & 116.21 & 2.44 & 0.96 \\
\hline 109.20 & 2.40 & 1.14 & 116.30 & 2.37 & 0.90 \\
\hline 109.30 & 2.19 & 0.97 & 116.30 & 2.46 & 1.19 \\
\hline 109.41 & 2.33 & 1.14 & 116.44 & 2.38 & 1.09 \\
\hline 109.60 & 2.27 & 1.14 & 116.50 & 2.48 & 1.07 \\
\hline 109.70 & 2.41 & 1.16 & 116.60 & 2.48 & 0.94 \\
\hline 109.80 & 2.41 & 1.03 & 116.60 & 2.49 & 1.21 \\
\hline 109.90 & 2.16 & 1.07 & 116.70 & 2.23 & 0.89 \\
\hline 110.00 & 2.25 & 1.00 & 116.81 & 2.29 & 0.83 \\
\hline 110.00 & 2.09 & 0.94 & 116.99 & 2.40 & 0.79 \\
\hline 110.00 & 2.08 & 0.91 & 117.09 & 2.61 & 1.01 \\
\hline 110.10 & 2.64 & 0.99 & 117.20 & 2.55 & 0.80 \\
\hline 110.20 & 2.34 & 1.00 & 117.20 & 2.43 & 1.05 \\
\hline 110.30 & 2.32 & 0.99 & 117.30 & 2.27 & 0.97 \\
\hline 110.30 & 1.94 & 0.67 & 117.30 & 2.43 & 1.06 \\
\hline 110.40 & 2.20 & 0.97 & 117.44 & 2.86 & 0.97 \\
\hline 110.49 & 2.09 & 1.01 & 117.62 & 2.24 & 0.82 \\
\hline 110.61 & 2.23 & 0.92 & 117.62 & 2.46 & 0.87 \\
\hline 110.70 & 2.27 & 1.02 & 117.70 & 2.56 & 1.01 \\
\hline 110.70 & 2.43 & 0.88 & 117.80 & 2.53 & 1.22 \\
\hline 110.80 & 2.50 & 1.06 & 117.80 & 2.51 & 1.25 \\
\hline 110.91 & 2.37 & 1.09 & 117.94 & 2.29 & 1.09 \\
\hline 111.08 & 2.32 & 1.28 & 117.98 & 2.36 & 1.08 \\
\hline 111.20 & 2.35 & 1.20 & 117.98 & 2.16 & 1.20 \\
\hline 111.30 & 2.39 & 1.34 & 118.10 & 2.29 & 1.12 \\
\hline 111.50 & 2.23 & 1.22 & 118.10 & 2.65 & 1.15 \\
\hline 111.60 & 2.31 & 1.31 & 118.80 & 2.77 & 0.80 \\
\hline 111.70 & 2.34 & 1.04 & 118.82 & 2.91 & 0.88 \\
\hline 111.80 & 2.32 & 1.14 & 119.03 & 2.74 & 0.76 \\
\hline 111.90 & 2.47 & 1.16 & 119.42 & 2.32 & 0.85 \\
\hline
\end{tabular}


Appendix (continued).

\begin{tabular}{llllll}
\hline $\begin{array}{c}\text { Sample } \\
\text { depth }(\mathrm{m})\end{array}$ & $\delta^{18} \mathrm{O}$ & $\delta^{13} \mathrm{C}$ & $\begin{array}{c}\text { Sample } \\
\text { depth }(\mathrm{m})\end{array}$ & $\delta^{18} \mathrm{O}$ & $\delta^{13} \mathrm{C}$
\end{tabular}

Hole 552A (Cont.)

P. wuellerstorfi (Cont.)

\begin{tabular}{|c|c|c|c|c|c|}
\hline 119.62 & 2.33 & 1.00 & 125.92 & 2.48 & 1.22 \\
\hline 119.92 & 2.29 & 0.92 & 126.04 & 2.15 & 0.99 \\
\hline 120.00 & 2.48 & 0.80 & 126.12 & 2.08 & 0.83 \\
\hline 120.10 & 2.43 & 0.79 & 126.22 & 2.22 & 0.93 \\
\hline 120.22 & 2.46 & 0.59 & 126.34 & 2.42 & 1.18 \\
\hline 120.32 & 2.47 & 0.63 & 126.42 & 2.26 & 0.98 \\
\hline 120.32 & 2.59 & 0.75 & 126.52 & 2.44 & 0.92 \\
\hline 120.42 & 2.72 & 0.72 & 126.61 & 2.24 & 0.91 \\
\hline 120.53 & 2.64 & 0.72 & 126.72 & 2.25 & 0.71 \\
\hline 120.53 & 2.77 & 0.78 & 126.84 & 1.96 & 1.11 \\
\hline 120.62 & 2.37 & 0.90 & 126.84 & 2.50 & 0.80 \\
\hline 120.71 & 2.36 & 0.83 & 126.93 & 2.23 & 1.04 \\
\hline 120.82 & 2.23 & 0.67 & 127.02 & 2.11 & 1.04 \\
\hline 120.92 & 2.51 & 0.83 & 127.12 & 1.78 & 1.18 \\
\hline 120.92 & 2.38 & 0.79 & 127.22 & 1.96 & 1.14 \\
\hline 121.03 & 2.45 & 0.72 & 127.32 & 2.22 & 1.14 \\
\hline 121.12 & 2.39 & 0.75 & 127.42 & 2.30 & 1.26 \\
\hline 121.22 & 2.48 & 0.87 & 127.42 & 2.24 & 0.99 \\
\hline 121.32 & 2.43 & 0.75 & 127.64 & 1.84 & 0.80 \\
\hline 121.42 & 2.45 & 0.60 & 127.82 & 2.12 & 0.62 \\
\hline 121.59 & 2.60 & 0.55 & 127.92 & 2.40 & 1.19 \\
\hline 121.71 & 2.41 & 0.76 & 127.92 & 2.30 & 0.69 \\
\hline 121.82 & 2.54 & 0.95 & 128.02 & 2.17 & 0.80 \\
\hline 121.82 & 2.57 & 0.83 & 128.14 & 2.33 & 0.92 \\
\hline 121.92 & 2.40 & 1.05 & 128.52 & 2.48 & 0.77 \\
\hline 122.02 & 2.42 & 1.01 & 128.52 & 2.22 & 0.62 \\
\hline 122.12 & 2.26 & 0.79 & 128.62 & 2.78 & 0.93 \\
\hline 122.20 & 2.32 & 0.96 & 128.72 & 2.42 & 0.73 \\
\hline 122.32 & 2.40 & 0.71 & 128.82 & 2.38 & 0.74 \\
\hline 122.42 & 2.59 & 0.92 & 128.82 & 2.25 & 0.62 \\
\hline 122.62 & 2.27 & 0.80 & 128.92 & 2.55 & 0.93 \\
\hline 122.72 & 2.32 & 0.72 & 129.02 & 2.42 & 0.91 \\
\hline 122.82 & 2.51 & 0.61 & 129.12 & 2.45 & 1.05 \\
\hline 122.92 & 2.60 & 0.63 & 129.23 & 2.42 & 0.94 \\
\hline 123.02 & 2.46 & 0.94 & 129.32 & 2.32 & 0.95 \\
\hline 123.12 & 2.53 & 0.92 & 129.42 & 2.46 & 0.97 \\
\hline 123.12 & 2.49 & 0.94 & 129.53 & 2.39 & 0.91 \\
\hline 123.22 & 2.63 & 0.94 & 129.65 & 2.27 & 0.94 \\
\hline 123.52 & 2.45 & 0.66 & 129.74 & 2.34 & 1.11 \\
\hline 123.62 & 2.74 & 0.87 & 129.83 & 2.26 & 0.92 \\
\hline 123.72 & 2.44 & 0.82 & 129.92 & 2.30 & 0.90 \\
\hline 123.72 & 2.25 & 0.64 & 130.02 & 2.31 & 0.98 \\
\hline 123.72 & 2.15 & 0.81 & 130.14 & 2.34 & 0.87 \\
\hline 123.81 & 2.29 & 0.80 & 130.22 & 2.31 & 0.75 \\
\hline 123.81 & 2.47 & 0.67 & 130.27 & 2.40 & 0.86 \\
\hline 123.84 & 2.38 & 0.86 & 130.36 & 2.45 & 0.84 \\
\hline 123.91 & 2.38 & 0.90 & 130.44 & 2.39 & 0.45 \\
\hline 124.03 & 2.49 & 1.09 & 130.53 & 2.40 & 0.92 \\
\hline 124.12 & 2.54 & 1.16 & 130.63 & 2.17 & 0.87 \\
\hline 124.21 & 2.45 & 1.08 & 130.73 & 2.45 & 0.98 \\
\hline 124.31 & 2.14 & 0.93 & 130.82 & 2.27 & 0.83 \\
\hline 124.51 & 2.21 & 0.67 & 130.93 & 1.98 & 0.66 \\
\hline 124.61 & 2.41 & 0.80 & 131.02 & 2.40 & 0.67 \\
\hline 124.72 & 2.27 & 0.38 & 131.10 & 2.53 & 0.62 \\
\hline 124.91 & 2.15 & 0.65 & 131.22 & 2.57 & 0.49 \\
\hline 125.01 & 2.10 & 0.93 & 131.32 & 2.24 & 0.81 \\
\hline 125.11 & 2.12 & 0.96 & 131.42 & 2.42 & 0.51 \\
\hline 125.22 & 2.05 & 0.68 & 131.52 & 2.26 & 0.61 \\
\hline 125.31 & 2.43 & 0.58 & 131.63 & 2.54 & 0.96 \\
\hline 125.34 & 2.56 & 0.97 & 131.72 & 2.38 & 1.07 \\
\hline 125.43 & 2.65 & 1.20 & 131.73 & 2.38 & 0.90 \\
\hline 125.53 & 2.33 & 0.60 & 131.83 & 2.19 & 0.95 \\
\hline 125.62 & 2.31 & 0.83 & 131.93 & 2.33 & 0.98 \\
\hline 125.72 & 2.49 & 1.07 & 132.03 & 2.56 & 0.87 \\
\hline 125.82 & 2.25 & 0.91 & 132.13 & 2.39 & 0.63 \\
\hline
\end{tabular}

Appendix (continued).

\begin{tabular}{cccccc}
\hline $\begin{array}{c}\text { Sample } \\
\text { depth }(\mathrm{m})\end{array}$ & $\delta^{18} \mathrm{O}$ & $\delta^{13} \mathrm{C}$ & $\begin{array}{c}\text { Sample } \\
\text { depth }(\mathrm{m})\end{array}$ & $\delta^{18} \mathrm{O}$ & $\delta^{13} \mathrm{C}$
\end{tabular}

Hole 552A (Cont.)

P. wuellerstorfi (Cont.)

\begin{tabular}{|c|c|c|c|c|c|}
\hline 132.23 & 2.45 & 0.47 & 138.40 & 2.69 & 0.75 \\
\hline 132.33 & 2.29 & 0.52 & 138.50 & 2.46 & 0.94 \\
\hline 132.44 & 2.41 & 0.70 & 138.50 & 2.38 & 0.88 \\
\hline 132.53 & 2.27 & 0.79 & 138.60 & 2.37 & 0.97 \\
\hline 132.60 & 2.38 & 0.78 & 138.70 & 2.35 & 0.85 \\
\hline 132.70 & 2.44 & 0.71 & 138.80 & 2.18 & 1.09 \\
\hline 132.84 & 2.65 & 0.85 & 138.90 & 2.46 & 0.79 \\
\hline 132.94 & 2.34 & 0.80 & 139.00 & 2.33 & 0.94 \\
\hline 133.14 & 2.40 & 1.06 & 139.00 & 1.93 & 0.50 \\
\hline 133.22 & 2.26 & 1.09 & 139.08 & 2.41 & 0.82 \\
\hline 133.34 & 1.77 & 1.13 & 139.10 & 2.26 & 0.84 \\
\hline 133.44 & 2.23 & 0.89 & 139.10 & 2.14 & 0.71 \\
\hline 133.50 & 2.59 & 1.05 & 139.10 & 2.00 & 0.51 \\
\hline 133.60 & 2.65 & 0.95 & 139.30 & 2.27 & 0.73 \\
\hline 133.70 & 2.43 & 1.03 & 139.30 & 2.34 & 0.76 \\
\hline 133.80 & 2.64 & 1.14 & 139.40 & 2.45 & 0.77 \\
\hline 133.90 & 2.37 & 0.85 & 139.50 & 2.45 & 0.74 \\
\hline 133.90 & 2.07 & 0.71 & 139.58 & 2.35 & 0.75 \\
\hline 133.96 & 2.37 & 0.77 & 139.60 & 2.30 & 0.81 \\
\hline 134.02 & 2.60 & 0.98 & 139.70 & 2.55 & 0.80 \\
\hline 134.10 & 2.52 & 0.58 & 139.80 & 1.98 & 0.83 \\
\hline 134.20 & 2.47 & 0.76 & 139.90 & 2.15 & 0.81 \\
\hline 134.38 & 2.40 & 0.95 & 140.00 & 2.21 & 0.60 \\
\hline 134.51 & 2.31 & 1.03 & 140.08 & 2.38 & 0.53 \\
\hline 134.61 & 2.30 & 1.01 & 140.10 & 2.00 & 0.63 \\
\hline 134.80 & 2.38 & 0.77 & 140.20 & 2.59 & 0.57 \\
\hline 134.89 & 2.37 & 0.70 & 140.40 & 2.08 & 0.63 \\
\hline 135.00 & 2.47 & 0.77 & 140.50 & 2.17 & 0.78 \\
\hline 135.10 & 2.42 & 0.52 & 140.58 & 2.20 & 0.35 \\
\hline 135.20 & 2.48 & 0.78 & 140.70 & 2.20 & 0.70 \\
\hline 135.30 & 2.43 & 0.97 & 140.80 & 1.91 & 0.90 \\
\hline 135.40 & 2.48 & 1.07 & 140.90 & 1.95 & 0.72 \\
\hline 135.51 & 2.51 & 1.03 & 141.00 & 2.01 & 0.64 \\
\hline 135.51 & 2.18 & 1.08 & 141.08 & 2.26 & 0.88 \\
\hline 135.60 & 2.20 & 0.77 & 141.10 & 2.25 & 0.84 \\
\hline 135.70 & 2.58 & 0.94 & 141.20 & 2.48 & 0.79 \\
\hline 135.80 & 2.44 & 0.96 & 141.30 & 2.29 & 0.72 \\
\hline 135.90 & 2.36 & 0.77 & 141.40 & 2.37 & 0.68 \\
\hline 136.02 & 2.49 & 0.78 & 141.50 & 2.30 & 0.88 \\
\hline 136.10 & 2.62 & 1.00 & 141.58 & 2.25 & 0.66 \\
\hline 136.10 & 2.18 & 0.75 & 141.60 & 2.46 & 1.03 \\
\hline 136.20 & 2.29 & 0.94 & 141.70 & 2.55 & 1.01 \\
\hline 136.31 & 2.41 & 1.02 & 141.80 & 2.03 & 0.84 \\
\hline 136.43 & 2.70 & 1.21 & 141.90 & 2.38 & 0.69 \\
\hline 136.50 & 2.25 & 1.01 & 142.00 & 2.14 & 0.64 \\
\hline 136.60 & 2.42 & 0.93 & 142.08 & 2.22 & 0.45 \\
\hline 136.70 & 2.38 & 1.03 & 142.10 & 2.23 & 0.66 \\
\hline 136.70 & 2.43 & 1.01 & 142.20 & 2.48 & 0.60 \\
\hline 136.80 & 2.45 & 1.01 & 142.30 & 2.43 & 0.81 \\
\hline 136.92 & 2.28 & 1.02 & 142.40 & 2.39 & 0.98 \\
\hline 137.01 & 2.36 & 1.04 & 142.50 & 1.91 & 0.90 \\
\hline 137.10 & 2.38 & 1.13 & 142.58 & 1.98 & 0.80 \\
\hline 137.20 & 2.30 & 0.82 & 142.60 & 2.17 & 0.86 \\
\hline 137.30 & 2.41 & 0.98 & 142.80 & 2.31 & 0.90 \\
\hline 137.44 & 2.46 & 0.64 & 142.90 & 2.40 & 0.99 \\
\hline 137.52 & 2.40 & 0.70 & 143.08 & 2.38 & 0.79 \\
\hline 137.52 & 2.23 & 0.51 & 143.10 & 2.61 & 1.16 \\
\hline 137.61 & 2.42 & 0.71 & 143.30 & 2.40 & 1.03 \\
\hline 137.73 & 2.56 & 0.83 & 143.40 & 2.46 & 0.93 \\
\hline 137.83 & 2.44 & 0.94 & 143.50 & 2.39 & 0.92 \\
\hline 137.94 & 2.50 & 0.64 & 143.80 & 2.08 & 0.76 \\
\hline 138.00 & 2.39 & 0.84 & 144.10 & 2.38 & 1.05 \\
\hline 138.00 & 2.33 & 0.90 & 144.58 & 2.32 & 0.56 \\
\hline 138.11 & 2.50 & 0.88 & 145.08 & 2.06 & 0.97 \\
\hline 8.20 & 2.45 & 0.82 & 145.60 & 2.57 & 1.04 \\
\hline
\end{tabular}


Appendix (continued).

\begin{tabular}{llllll}
\hline Sample & & & \multicolumn{3}{c}{ Sample } \\
depth $(\mathrm{m})$ & $\delta^{18} \mathrm{O}$ & $\delta^{13} \mathrm{C}$ & & $\begin{array}{c}\text { depth }(\mathrm{m}) \\
{ }^{18} \mathrm{O}\end{array}$ & $\delta^{13} \mathrm{C}$
\end{tabular}

Hole 552A (Cont.)

P. wuellerstorfi (Cont.)

$\begin{array}{lll}146.10 & 2.29 & 0.82 \\ 146.60 & 2.15 & 0.88 \\ 147.10 & 2.31 & 0.84 \\ 147.56 & 2.33 & 1.00 \\ 148.10 & 2.19 & 0.97 \\ 148.60 & 2.32 & 1.04 \\ 149.60 & 2.48 & 1.26 \\ 150.10 & 2.02 & 0.94 \\ 150.10 & 2.24 & 0.93 \\ 150.62 & 2.17 & 1.04 \\ 151.11 & 2.28 & 1.28 \\ 151.60 & 2.29 & 1.25 \\ 152.10 & 2.27 & 1.30 \\ 152.10 & 2.26 & 1.28 \\ 152.60 & 2.27 & 1.13 \\ 153.10 & 2.44 & 1.27 \\ 153.60 & 1.96 & 1.27 \\ 154.10 & 1.98 & 1.02 \\ 154.60 & 2.27 & 1.46 \\ 155.10 & 2.26 & 1.50 \\ 155.64 & 2.32 & 1.38 \\ 156.12 & 2.24 & 1.48 \\ 156.50 & 2.55 & 1.53 \\ 157.62 & 2.35 & 1.04 \\ 162.10 & 2.35 & 1.34 \\ 163.46 & 2.23 & 1.15 \\ 167.10 & 2.20 & 0.89 \\ 168.10 & 2.14 & 1.00 \\ 168.61 & 2.15 & 0.99\end{array}$

\section{G. bulloides}

\begin{tabular}{llllll}
104.00 & 1.20 & 0.17 & 108.11 & 1.83 & 0.38 \\
104.00 & 1.52 & 0.48 & 108.20 & 1.79 & 0.51 \\
104.10 & 1.20 & 0.26 & 108.30 & 1.48 & 0.29 \\
104.22 & 1.27 & 0.26 & 108.40 & 1.67 & 0.15 \\
104.22 & 1.62 & 0.72 & 108.50 & 1.68 & 0.07 \\
104.22 & 1.08 & 0.10 & 108.60 & 1.97 & 0.45 \\
104.22 & 0.87 & -0.12 & 108.60 & 1.46 & 0.22 \\
104.22 & 0.96 & 0.15 & 108.70 & 1.53 & 0.12 \\
104.30 & 1.65 & 0.62 & 108.80 & 1.69 & 0.11 \\
104.30 & 1.48 & 0.55 & 108.80 & 1.65 & 0.21 \\
104.40 & 1.76 & 0.63 & 108.90 & 1.53 & 0.25 \\
104.49 & 1.58 & 0.59 & 109.10 & 1.24 & 0.00 \\
104.60 & 1.62 & 0.55 & 109.10 & 1.63 & 0.10 \\
104.70 & 1.53 & 0.60 & 109.20 & 1.97 & 0.39 \\
104.70 & 1.26 & 0.48 & 109.30 & 1.65 & 0.67 \\
104.80 & 1.31 & 0.34 & 109.30 & 1.80 & 0.16 \\
104.80 & 1.44 & 0.48 & 109.41 & 1.59 & 0.61 \\
104.90 & 1.48 & 0.70 & 109.52 & 1.25 & 0.22 \\
104.99 & 1.66 & 0.52 & 109.60 & 1.24 & 0.64 \\
105.03 & 1.82 & 0.10 & 109.70 & 1.52 & 0.62 \\
105.10 & 1.31 & 0.07 & 109.80 & 1.52 & 0.44 \\
105.20 & 1.34 & 0.05 & 109.90 & 1.68 & 0.50 \\
105.30 & 1.63 & 0.48 & 109.90 & 1.36 & 0.22 \\
105.40 & 1.24 & 0.64 & 110.00 & 1.60 & 0.13 \\
105.40 & 1.56 & 0.64 & 110.10 & 1.60 & 0.23 \\
105.50 & 1.39 & 0.74 & 110.20 & 1.64 & 0.35 \\
105.60 & 1.56 & 0.94 & 110.30 & 1.65 & 0.46 \\
105.69 & 1.25 & 0.65 & 110.40 & 1.52 & 0.30 \\
105.80 & 1.39 & 0.22 & 110.40 & 1.55 & 0.31 \\
105.86 & 0.86 & 0.33 & 110.49 & 1.45 & 0.54 \\
105.86 & 1.24 & 0.40 & 110.61 & 1.22 & 0.21 \\
105.96 & 1.59 & 0.48 & 110.70 & 1.78 & 0.60 \\
106.02 & 1.56 & 0.09 & 110.80 & 1.75 & 0.56 \\
& & & & & \\
\hline 103 & & & &
\end{tabular}

Appendix (continued).

\begin{tabular}{|c|c|c|c|}
\hline $\begin{array}{c}\text { Sample } \\
\text { depth (m) }\end{array}$ & $\delta^{18} \mathrm{O} \quad \delta^{13} \mathrm{C}$ & $\begin{array}{c}\text { Sample } \\
\text { depth (m) }\end{array}$ & $\delta^{18} 0$ \\
\hline
\end{tabular}

Hole 552A (Cont.)

G. bulloides (Cont.)

\begin{tabular}{|c|c|c|c|c|c|c|c|c|}
\hline 106.14 & 2.11 & 0.52 & 110.80 & 1.86 & 0.74 & 115.94 & 1.27 & 0.28 \\
\hline 106.14 & 2.37 & 0.24 & 110.91 & 1.76 & 0.56 & 115.94 & 1.25 & 0.37 \\
\hline 106.17 & 1.74 & -0.25 & 110.91 & 1.53 & 0.56 & 116.03 & 1.18 & 0.26 \\
\hline 106.23 & 1.70 & 0.09 & 111.02 & 1.27 & 0.19 & 116.03 & 1.24 & 0.28 \\
\hline 106.30 & 2.08 & 0.41 & 111.08 & 1.73 & 0.62 & 116.11 & 1.07 & 0.13 \\
\hline 106.33 & 2.02 & 0.07 & 111.08 & 1.29 & 0.37 & 116.21 & 1.15 & 0.37 \\
\hline 106.30 & 2.05 & -0.23 & 111.08 & 1.65 & 0.58 & 116.30 & 1.11 & 0.06 \\
\hline 106.30 & 1.84 & 0.22 & 111.20 & 1.82 & 0.87 & 116.30 & 1.18 & 0.23 \\
\hline 106.41 & 1.76 & 0.39 & 111.20 & 1.69 & 0.78 & 116.44 & 1.36 & 0.12 \\
\hline 106.50 & 1.55 & 0.33 & 111.30 & 1.87 & 0.99 & 116.50 & 1.17 & 0.21 \\
\hline 106.52 & 1.90 & 0.27 & 111.38 & 1.54 & 0.86 & 116.60 & 1.21 & 0.02 \\
\hline 106.60 & 1.87 & 0.16 & 111.38 & 1.64 & 0.70 & 116.70 & 1.34 & 0.04 \\
\hline 106.70 & 1.98 & 0.37 & 111.50 & 1.68 & 0.67 & 116.81 & 1.15 & -0.02 \\
\hline 106.80 & 1.87 & 0.69 & 111.60 & 1.49 & 0.43 & 116.81 & 1.28 & -0.09 \\
\hline 106.90 & 1.55 & 0.40 & 111.60 & 1.80 & 0.72 & 116.90 & 1.09 & -0.05 \\
\hline 106.90 & 1.74 & 0.56 & 111.70 & 1.31 & -0.02 & 116.99 & 1.48 & 0.13 \\
\hline 107.00 & 1.86 & 0.52 & 111.70 & 1.25 & 0.09 & 116.99 & 1.11 & -0.11 \\
\hline 107.09 & 1.75 & 0.42 & 111.80 & 1.40 & 0.23 & 117.09 & 1.18 & 0.00 \\
\hline 107.09 & 1.36 & 0.38 & 111.90 & 1.50 & 0.33 & 117.20 & 1.32 & 0.23 \\
\hline 107.20 & 1.47 & 0.14 & 112.01 & 1.80 & 0.52 & 117.30 & 1.44 & 0.26 \\
\hline 107.30 & 1.63 & 0.28 & 112.11 & 1.72 & 0.41 & 117.30 & 1.37 & 0.08 \\
\hline 107.40 & 1.46 & 0.41 & 112.20 & 1.76 & 0.41 & 117.44 & 1.41 & -0.22 \\
\hline 107.52 & 1.31 & 0.40 & 112.30 & 1.69 & 0.44 & 117.53 & 1.61 & 0.09 \\
\hline 107.61 & 1.23 & 0.32 & 112.30 & 1.61 & 0.32 & 117.53 & 1.73 & 0.00 \\
\hline 107.70 & 1.52 & 0.33 & 112.41 & 1.39 & 0.22 & 117.70 & 1.59 & 0.20 \\
\hline 107.80 & 1.70 & 0.37 & 112.56 & 1.44 & 0.03 & 117.70 & 1.33 & 0.06 \\
\hline 107.80 & 1.67 & 0.48 & 112.60 & 1.52 & 0.18 & 117.80 & 1.27 & 0.16 \\
\hline 107.91 & 1.73 & 0.33 & 112.70 & 1.70 & 0.32 & 117.80 & 1.51 & 0.20 \\
\hline 108.03 & 1.70 & 0.04 & 112.70 & 1.56 & 0.23 & 117.94 & 1.24 & 0.19 \\
\hline 108.03 & 1.52 & 0.46 & 112.81 & 1.47 & 0.02 & 117.98 & 1.27 & 0.38 \\
\hline 108.06 & 1.59 & -0.03 & 112.90 & 1.85 & 0.67 & 117.98 & 1.21 & 0.30 \\
\hline 108.11 & 1.90 & 0.45 & 113.00 & 1.73 & 0.44 & 118.10 & 0.98 & 0.31 \\
\hline 108.11 & 1.83 & 0.38 & 113.10 & 1.69 & 0.25 & 118.10 & 1.35 & 0.46 \\
\hline 108.20 & 1.79 & 0.51 & 113.10 & 1.74 & 0.28 & 118.70 & 1.61 & -0.03 \\
\hline 108.30 & 1.48 & 0.29 & 113.70 & 1.32 & -0.23 & 118.80 & 1.47 & -0.14 \\
\hline 108.40 & 1.67 & 0.15 & 113.78 & 1.10 & 0.49 & 118.80 & 1.79 & -0.17 \\
\hline 108.50 & 1.68 & 0.07 & 113.93 & 1.08 & 0.11 & 118.82 & 1.71 & -0.01 \\
\hline 108.60 & 1.97 & 0.45 & 114.08 & 1.13 & 0.11 & 118.90 & 1.72 & -0.05 \\
\hline 108.60 & 1.46 & 0.22 & 114.20 & 1.42 & 0.23 & 119.03 & 1.97 & -0.29 \\
\hline 108.70 & 1.53 & 0.12 & 114.29 & 1.38 & 0.17 & 119.13 & 2.06 & -0.15 \\
\hline 108.80 & 1.69 & 0.11 & 114.40 & 1.31 & 0.17 & 119.23 & 2.06 & -0.16 \\
\hline 108.80 & 1.65 & 0.21 & 114.55 & 1.18 & 0.24 & 119.33 & 1.96 & -0.05 \\
\hline 108.90 & 1.53 & 0.25 & 114.68 & 1.10 & -0.18 & 119.42 & 1.98 & -0.14 \\
\hline 109.10 & 1.24 & 0.00 & 114.78 & 1.38 & -0.07 & 119.52 & 2.04 & 0.22 \\
\hline 109.10 & 1.63 & 0.10 & 114.78 & 1.03 & -0.35 & 119.62 & 1.57 & 0.13 \\
\hline 109.20 & 1.97 & 0.39 & 114.88 & 1.47 & 0.27 & 119.72 & 1.60 & 0.07 \\
\hline 109.30 & 1.65 & 0.67 & 114.88 & 1.11 & -0.22 & 119.82 & 1.58 & -0.06 \\
\hline 109.30 & 1.80 & 0.16 & 114.94 & 1.43 & 0.21 & 119.92 & 1.22 & -0.39 \\
\hline 109.41 & 1.59 & 0.61 & 114.98 & 1.47 & 0.30 & 120.00 & 1.22 & -0.27 \\
\hline 109.52 & 1.25 & 0.22 & 114.98 & 1.66 & 0.46 & 120.10 & 1.82 & -0.38 \\
\hline 109.60 & 1.24 & 0.64 & 114.98 & 1.61 & 0.31 & 120.22 & 1.50 & -0.40 \\
\hline 109.70 & 1.52 & 0.62 & 114.98 & 1.86 & 0.44 & 120.32 & 1.76 & -0.38 \\
\hline 109.80 & 1.52 & 0.44 & 115.01 & 1.71 & 0.34 & 120.32 & 1.67 & -0.36 \\
\hline 109.90 & 1.68 & 0.50 & 115.10 & 1.33 & 0.88 & 120.42 & 1.75 & -0.42 \\
\hline 109.90 & 1.36 & 0.22 & 115.10 & 1.29 & -0.02 & 120.53 & 1.57 & -0.46 \\
\hline 110.00 & 1.60 & 0.13 & 115.20 & 1.53 & 0.17 & 120.62 & 1.61 & -0.17 \\
\hline 110.10 & 1.60 & 0.23 & 115.20 & 1.56 & 0.30 & 120.71 & 1.14 & -0.54 \\
\hline 110.20 & 1.64 & 0.35 & 115.31 & 1.43 & 0.14 & 120.82 & 1.41 & -0.42 \\
\hline 110.30 & 1.65 & 0.46 & 115.31 & 1.59 & 0.34 & 120.92 & 1.72 & -0.24 \\
\hline 110.40 & 1.52 & 0.30 & 115.43 & 1.67 & 0.49 & 121.03 & 1.42 & -0.29 \\
\hline 110.40 & 1.55 & 0.31 & 115.52 & 1.57 & 0.41 & 121.12 & 1.39 & -0.38 \\
\hline 110.49 & 1.45 & 0.54 & 115.60 & 1.76 & 0.54 & 121.22 & 1.47 & -0.26 \\
\hline 110.61 & 1.22 & 0.21 & 115.60 & 1.80 & 0.39 & 121.32 & 1.64 & -0.15 \\
\hline 110.70 & 1.78 & 0.60 & 115.70 & 1.63 & 0.52 & 121.42 & 1.68 & -0.23 \\
\hline 110.80 & 1.75 & 0.56 & 115.80 & 1.48 & 0.42 & 121.50 & 1.67 & -0.31 \\
\hline
\end{tabular}


Appendix (continued).

\begin{tabular}{llllll}
\hline $\begin{array}{c}\text { Sample } \\
\text { depth (m) }\end{array}$ & $\delta^{18} \mathrm{O}$ & $\delta^{13} \mathrm{C}$ & $\begin{array}{c}\text { Sample } \\
\text { depth }(\mathrm{m})\end{array}$ & $\delta^{18} \mathrm{O}$ & $\delta^{13} \mathrm{C}$ \\
\hline
\end{tabular}

Hole 552A (Cont.)

\section{G. bulloides (Cont.)}

\begin{tabular}{|c|c|c|c|c|c|}
\hline 121.59 & 1.55 & -0.27 & 127.12 & 1.40 & 0.07 \\
\hline 121.71 & 1.51 & -0.06 & 127.22 & 1.57 & 0.12 \\
\hline 121.82 & 1.31 & -0.01 & 127.32 & 1.47 & 0.27 \\
\hline 121.82 & 1.27 & -0.16 & 127.42 & 1.43 & -0.16 \\
\hline 121.92 & 1.11 & -0.15 & 127.54 & 1.52 & -0.34 \\
\hline 122.02 & 1.58 & -0.16 & 127.64 & 1.50 & -0.19 \\
\hline 122.12 & 1.58 & -0.13 & 127.74 & 1.38 & -0.16 \\
\hline 122.20 & 1.52 & -0.26 & 127.82 & 1.46 & 0.18 \\
\hline 122.32 & 1.57 & -0.18 & 127.92 & 1.42 & 0.14 \\
\hline 122.42 & 1.57 & -0.08 & 128.02 & 1.29 & 0.14 \\
\hline 122.52 & 1.33 & -0.41 & 128.14 & 1.43 & 0.35 \\
\hline 122.52 & 1.36 & -0.41 & 128.22 & 1.56 & 0.23 \\
\hline 122.62 & 1.41 & -0.07 & 128.52 & 1.75 & -0.09 \\
\hline 122.72 & 1.40 & -0.49 & 128.62 & 1.74 & 0.03 \\
\hline 122.82 & 1.54 & -0.49 & 128.72 & 1.53 & -0.12 \\
\hline 122.92 & 1.65 & -0.42 & 128.72 & 1.32 & -0.39 \\
\hline 123.02 & 1.43 & -0.41 & 128.82 & 1.36 & -0.22 \\
\hline 123.12 & 1.43 & -0.23 & 128.92 & 1.49 & -0.01 \\
\hline 123.22 & 1.67 & 0.20 & 129.02 & 1.68 & -0.21 \\
\hline 123.52 & 1.64 & -0.27 & 129.12 & 1.55 & -0.03 \\
\hline 123.62 & 1.65 & -0.07 & 129.23 & 1.42 & -0.07 \\
\hline 123.72 & 1.70 & -0.11 & 129.32 & 1.31 & 0.10 \\
\hline 123.81 & 1.74 & -0.08 & 129.42 & 1.55 & -0.05 \\
\hline 123.84 & 1.57 & 0.00 & 129.53 & 1.55 & 0.25 \\
\hline 124.03 & 1.52 & -0.15 & 129.65 & 1.35 & 0.42 \\
\hline 124.12 & 1.37 & 0.29 & 129.74 & 1.37 & 0.24 \\
\hline 124.21 & 1.32 & -0.05 & 129.83 & 1.54 & 0.20 \\
\hline 124.31 & 1.72 & 0.10 & 129.92 & 1.44 & 0.13 \\
\hline 124.41 & 1.24 & -0.52 & 130.14 & 1.14 & 0.22 \\
\hline 124.51 & 1.47 & -0.18 & 130.22 & 1.29 & 0.46 \\
\hline 124.51 & 1.78 & -0.37 & 130.27 & 1.29 & -0.01 \\
\hline 124.61 & 1.42 & -0.26 & 130.36 & 1.47 & 0.30 \\
\hline 124.61 & 1.79 & -0.30 & 130.44 & 1.30 & 0.34 \\
\hline 124.72 & 1.72 & -0.35 & 130.53 & 1.41 & 0.51 \\
\hline 124.81 & 1.60 & -0.61 & 130.63 & 1.59 & 0.47 \\
\hline 124.81 & 1.44 & -0.37 & 130.73 & 1.34 & 0.26 \\
\hline 124.91 & 1.41 & -0.17 & 130.82 & 1.37 & 0.25 \\
\hline 124.91 & 1.11 & -0.48 & 130.93 & 1.33 & 0.21 \\
\hline 125.01 & 1.47 & 0.25 & 131.02 & 1.49 & -0.07 \\
\hline 125.11 & 1.23 & 0.11 & 131.10 & 1.48 & -0.03 \\
\hline 125.22 & 1.37 & -0.15 & 131.22 & 1.59 & 0.12 \\
\hline 125.31 & 1.49 & -0.10 & 131.32 & 1.43 & 0.14 \\
\hline 125.34 & 1.62 & -0.10 & 131.42 & 1.39 & 0.10 \\
\hline 125.43 & 1.63 & -0.23 & 131.52 & 1.21 & 0.18 \\
\hline 125.43 & 1.36 & -0.45 & 131.63 & 1.20 & 0.35 \\
\hline 125.53 & 1.48 & -0.37 & 131.72 & 1.37 & 0.35 \\
\hline 125.53 & 1.04 & -0.35 & 131.73 & 1.25 & 0.06 \\
\hline 125.62 & 1.54 & -0.06 & 131.83 & 1.25 & 0.19 \\
\hline 125.62 & 1.62 & -0.13 & 131.93 & 1.42 & 0.09 \\
\hline 125.72 & 1.35 & 0.15 & 132.03 & 1.55 & 0.02 \\
\hline 125.72 & 1.37 & 0.16 & 132.13 & 1.46 & -0.08 \\
\hline 125.82 & 1.09 & 0.19 & 132.23 & 1.52 & -0.11 \\
\hline 125.92 & 1.47 & 0.48 & 132.44 & 1.32 & 0.02 \\
\hline 126.04 & 1.51 & 0.48 & 132.53 & 1.06 & -0.09 \\
\hline 126.12 & 1.47 & 0.44 & 132.60 & 1.27 & 0.03 \\
\hline 126.22 & 1.54 & 0.45 & 132.70 & 1.50 & -0.09 \\
\hline 126.34 & 1.56 & 0.21 & 132.84 & 1.79 & 0.12 \\
\hline 126.42 & 1.51 & 0.27 & 132.92 & 1.62 & 0.18 \\
\hline 126.52 & 1.40 & 0.08 & 133.04 & 1.46 & 0.17 \\
\hline 126.61 & 1.47 & -0.21 & 133.14 & 1.49 & 0.19 \\
\hline 126.72 & 1.49 & -0.18 & 133.22 & 1.66 & 0.11 \\
\hline 126.84 & 1.53 & 0.01 & 133.23 & 1.71 & 0.29 \\
\hline 126.84 & 1.40 & -0.06 & 133.44 & 1.82 & 0.13 \\
\hline 126.93 & 1.49 & -0.22 & 133.50 & 1.43 & 0.15 \\
\hline 127.02 & 1.65 & 0.11 & 133.60 & 1.38 & 0.06 \\
\hline
\end{tabular}

Appendix (continued).

\begin{tabular}{cccccc}
\hline $\begin{array}{c}\text { Sample } \\
\text { depth }(\mathrm{m})\end{array}$ & $\delta^{18} \mathrm{O}$ & $\delta^{13} \mathrm{C}$ & $\begin{array}{c}\text { Sample } \\
\text { depth }(\mathrm{m})\end{array}$ & $\delta^{18} \mathrm{O}$ & $\delta^{13} \mathrm{C}$
\end{tabular}

Hole 552A (Cont.)

G. bulloides (Cont.)

\begin{tabular}{|c|c|c|c|c|c|}
\hline 133.70 & 1.62 & 0.04 & 138.70 & 1.51 & 0.16 \\
\hline 133.70 & 1.73 & 0.56 & 138.80 & 1.62 & 0.13 \\
\hline 133.80 & 1.58 & 0.27 & 138.90 & 1.74 & 0.12 \\
\hline 133.80 & 1.50 & 0.10 & 139.00 & 1.57 & 0.19 \\
\hline 133.90 & 1.58 & 0.22 & 139.08 & 1.70 & 0.50 \\
\hline 133.96 & 1.29 & 0.46 & 139.10 & 1.31 & 0.02 \\
\hline 133.96 & 1.28 & 0.09 & 139.20 & 1.40 & -0.08 \\
\hline 134.02 & 1.56 & 0.32 & 139.30 & 1.48 & -0.06 \\
\hline 134.10 & 1.52 & 0.12 & 139.40 & 1.53 & -0.16 \\
\hline 134.10 & 1.53 & 0.21 & 139.50 & 1.47 & -0.04 \\
\hline 134.20 & 1.54 & -0.10 & 139.58 & 1.93 & 0.35 \\
\hline 134.30 & 1.36 & -0.27 & 139.58 & 1.88 & 0.37 \\
\hline 134.38 & 1.43 & 0.05 & 139.60 & 1.70 & 0.23 \\
\hline 134.51 & 1.18 & 0.00 & 139.70 & 1.49 & -0.10 \\
\hline 134.61 & 1.29 & 0.29 & 139.80 & 1.03 & -0.25 \\
\hline 134.61 & 1.34 & 0.14 & 139.80 & 1.54 & 0.01 \\
\hline 134.71 & 1.07 & 0.03 & 139.90 & 1.43 & -0.04 \\
\hline 134.80 & 1.24 & 0.01 & 140.00 & 1.51 & -0.07 \\
\hline 134.89 & 1.42 & 0.04 & 140.08 & 1.39 & -0.0 \\
\hline 134.89 & 1.53 & 0.30 & 140.08 & 1.90 & 0.93 \\
\hline 135.00 & 1.36 & 0.10 & 140.10 & 1.39 & -0.22 \\
\hline 135.10 & 1.54 & -0.05 & 140.20 & 1.47 & -0.23 \\
\hline 135.10 & 1.48 & 0.13 & 140.30 & 1.55 & -0.45 \\
\hline 135.20 & 1.46 & 0.09 & 140.40 & 1.62 & -0.02 \\
\hline 135.30 & 1.18 & 0.14 & 140.50 & 1.85 & -0.06 \\
\hline 135.40 & 1.09 & 0.23 & 140.58 & 1.60 & 0.5 \\
\hline 135.46 & 1.44 & 0.28 & 140.58 & 1.78 & 0.6 \\
\hline 135.51 & 1.71 & 0.14 & 140.58 & 1.71 & 0.51 \\
\hline 135.51 & 1.32 & 0.14 & 140.60 & 1.70 & -0.17 \\
\hline 135.51 & 1.36 & 0.30 & 140.70 & 1.54 & 0.0 \\
\hline 135.60 & 1.32 & 0.08 & 140.80 & 1.59 & 0.0 \\
\hline 135.70 & 1.31 & 0.14 & 140.90 & 1.57 & $0.3 c$ \\
\hline 135.80 & 1.20 & -0.03 & 141.00 & 1.48 & 0.33 \\
\hline 135.90 & 1.32 & -0.08 & 141.08 & 1.76 & $0.7 \xi$ \\
\hline 135.90 & 1.21 & -0.03 & 141.08 & 1.69 & 0.7 \\
\hline 136.02 & 1.27 & 0.08 & 141.10 & 1.52 & 0.1 \\
\hline 136.10 & 1.28 & 0.02 & 141.20 & 1.65 & 0.2 \\
\hline 136.20 & 1.37 & 0.15 & 141.30 & 1.55 & 0.1 \\
\hline 136.31 & 1.42 & 0.43 & 141.40 & 1.46 & 0.0 \\
\hline 136.43 & 1.44 & -0.01 & 141.50 & 1.29 & 0.2 \\
\hline 136.50 & 1.55 & 0.29 & 141.60 & 1.69 & 0. \\
\hline 136.60 & 1.18 & -0.06 & 141.70 & 1.34 & 0.0 \\
\hline 136.70 & 1.11 & 0.03 & 141.80 & 1.68 & 0.2 \\
\hline 136.80 & 1.45 & 0.03 & 141.90 & 1.69 & 0.1 \\
\hline 136.92 & 1.36 & -0.08 & 142.00 & 1.76 & 0 \\
\hline 136.92 & 1.55 & 0.28 & 142.10 & 1.66 & 0.1 \\
\hline 136.96 & 1.51 & -0.04 & 142.20 & 1.84 & 0.1 \\
\hline 137.01 & 0.96 & -0.04 & 142.30 & 1.70 & 0.1 \\
\hline 137.01 & 1.38 & 0.12 & 142.40 & 1.64 & 0.3 \\
\hline 137.10 & 1.34 & 0.26 & 142.50 & 1.44 & 0.3 \\
\hline 137.20 & 1.39 & 0.24 & 142.60 & 1.46 & 0.3 \\
\hline 137.30 & 1.31 & 0.35 & 142.70 & 1.70 & 0.6 \\
\hline 137.44 & 1.57 & 0.45 & 142.80 & 1.63 & 0.5 \\
\hline 137.44 & 1.66 & 0.50 & 142.90 & 1.60 & 0.5 \\
\hline 137.52 & 1.63 & 0.17 & 143.00 & 1.71 & 0.4 \\
\hline 137.61 & 1.60 & 0.29 & 143.10 & 1.70 & 0.5 \\
\hline 137.73 & 1.55 & 0.65 & 143.20 & 1.65 & 0.4 \\
\hline 137.83 & 1.18 & -0.12 & 143.30 & 1.78 & 0.5 \\
\hline 137.94 & 1.48 & 0.17 & 143.40 & 1.70 & 0.4 \\
\hline 138.00 & 1.22 & 0.02 & 143.50 & 1.67 & 0.4 \\
\hline 138.11 & 1.71 & 0.65 & 143.60 & 1.62 & 0.2 \\
\hline 138.20 & 1.59 & 0.37 & 144.10 & 1.44 & -0.0 \\
\hline 138.40 & 1.39 & 0.18 & 145.60 & 1.72 & 0.3 \\
\hline 138.50 & 1.67 & 0.20 & 146.10 & 1.61 & 0.6 \\
\hline 138.50 & 1.66 & 0.41 & 147.40 & 1.41 & 0.6 \\
\hline
\end{tabular}


Appendix (continued).

\begin{tabular}{|c|c|c|c|c|c|}
\hline $\begin{array}{c}\text { Sample } \\
\text { depth (m) }\end{array}$ & $\delta^{18} \mathrm{O}$ & $\delta^{13} \mathrm{C}$ & $\begin{array}{c}\text { Sample } \\
\text { depth (m) }\end{array}$ & $\delta^{18} \mathrm{O}$ & $\delta^{13} \mathrm{C}$ \\
\hline
\end{tabular}

Hole 552A (Cont.)

G. bulloides (Cont.)

$\begin{array}{lll}147.56 & 1.55 & 0.87 \\ 148.10 & 1.50 & 0.81 \\ 148.60 & 1.32 & 0.49 \\ 149.10 & 1.50 & 0.82 \\ 149.60 & 1.38 & 1.06 \\ 150.62 & 1.43 & 1.22 \\ 151.11 & 1.67 & 0.99 \\ 151.60 & 1.48 & 0.77 \\ 152.10 & 1.58 & 1.08 \\ 152.60 & 1.51 & 0.90 \\ 153.10 & 1.29 & 1.24 \\ 153.60 & 1.38 & 1.32 \\ 154.10 & 1.63 & 1.25 \\ 154.30 & 1.43 & 0.74 \\ 154.60 & 1.35 & 0.73 \\ 155.10 & 1.34 & 0.84 \\ 155.64 & 1.44 & 1.24 \\ 156.12 & 1.50 & 1.06 \\ 156.50 & 1.43 & 1.16 \\ 157.10 & 1.60 & 1.47 \\ 157.62 & 1.52 & 0.67 \\ 158.10 & 1.44 & 0.90 \\ 158.60 & 1.60 & 1.00 \\ 159.12 & 1.78 & 1.37 \\ 160.10 & 1.65 & 1.44 \\ 160.60 & 1.68 & 1.49 \\ 161.13 & 1.64 & 0.95 \\ 161.30 & 1.22 & 0.45 \\ 161.60 & 1.69 & 1.11 \\ 162.10 & 1.48 & 0.85 \\ 162.60 & 1.73 & 1.07 \\ 163.10 & 1.54 & 0.81 \\ 163.46 & 1.74 & 0.88 \\ 163.61 & 1.51 & 1.29 \\ 164.10 & 1.26 & 0.29 \\ 164.60 & 1.25 & 1.05 \\ 165.10 & 1.49 & 0.96 \\ 165.60 & 1.76 & 0.42 \\ 165.60 & 1.66 & 0.27 \\ 166.10 & 1.72 & 0.66 \\ 166.60 & 1.67 & 0.94 \\ 167.10 & 1.34 & 0.69 \\ 167.62 & 1.42 & 0.62 \\ 168.10 & 1.51 & 1.05 \\ 168.49 & 1.43 & 0.70 \\ 168.61 & 1.27 & 0.41 \\ 169.10 & 1.14 & 1.01 \\ 169.62 & 1.10 & 1.32\end{array}$

Cibididoides spp.

\begin{tabular}{llllll}
104.00 & 2.24 & 0.79 & 287.28 & 2.20 & 1.34 \\
104.10 & 2.57 & 0.92 & 287.50 & 2.23 & 0.98 \\
104.90 & 2.52 & 0.73 & 287.80 & 2.25 & 1.12 \\
105.30 & 2.54 & 0.99 & 288.00 & 2.00 & 1.28 \\
105.60 & 2.44 & 0.80 & 288.42 & 2.18 & 1.34 \\
106.14 & 2.77 & 0.66 & 288.90 & 2.09 & 1.35 \\
106.30 & 2.82 & 0.64 & 289.10 & 2.05 & 1.38 \\
106.41 & 2.64 & 0.79 & 289.40 & 2.25 & 1.46 \\
113.70 & 2.13 & 0.61 & 289.60 & 2.17 & 1.46 \\
114.98 & 1.83 & 0.53 & 289.90 & 2.45 & 1.56 \\
115.01 & 2.49 & 0.88 & 290.10 & 2.18 & 1.50 \\
117.53 & 2.69 & 0.54 & 290.40 & 2.25 & 1.56 \\
118.70 & 2.80 & 0.74 & 290.60 & 2.12 & 1.26 \\
118.90 & 2.89 & 0.84 & 290.90 & 2.15 & 1.28 \\
& & & & & \\
\hline
\end{tabular}

$\begin{array}{lll}119.03 & 2.99 & 0.77 \\ 119.13 & 2.85 & 0.75 \\ 119.23 & 2.75 & 0.92 \\ 119.33 & 2.52 & 0.89 \\ 119.42 & 2.81 & 0.22 \\ 119.52 & 2.45 & 0.94 \\ 119.62 & 2.48 & 1.06 \\ 119.72 & 2.37 & 0.80 \\ 119.72 & 2.31 & 0.74 \\ 119.82 & 2.33 & 0.80 \\ 119.92 & 2.42 & 0.84 \\ 120.00 & 2.44 & 0.64 \\ 120.10 & 2.66 & 0.71 \\ 120.82 & 2.49 & 0.64 \\ 120.92 & 2.58 & 0.61 \\ 121.03 & 2.45 & 0.72 \\ 121.12 & 2.63 & 0.67 \\ 121.22 & 2.52 & 0.73\end{array}$

Hole 610 E
Appendix (continued).

\begin{tabular}{llllll}
\hline $\begin{array}{l}\text { Sample } \\
\text { depth }(\mathrm{m})\end{array}$ & $\delta^{18} \mathrm{O}$ & $\delta^{13} \mathrm{C}$ & $\begin{array}{c}\text { Sample } \\
\text { depth }(\mathrm{m})\end{array}$ & $\delta^{18} \mathrm{O}$ & $\delta^{13} \mathrm{C}$ \\
\hline
\end{tabular}

Hole 610E (Cont.)

P. wuellerstorfi (Cont.)

$\begin{array}{lll}291.10 & 2.21 & 1.48 \\ 291.40 & 2.25 & 1.50 \\ 291.60 & 1.98 & 1.47 \\ 292.10 & 2.05 & 1.47 \\ 292.40 & 2.27 & 1.32 \\ 292.90 & 2.23 & 1.29 \\ 293.40 & 2.15 & 1.40 \\ 294.40 & 2.33 & 1.52 \\ 294.90 & 2.49 & 1.43 \\ 295.40 & 2.21 & 1.41 \\ 295.90 & 2.34 & 1.29 \\ 295.90 & 2.05 & 1.38 \\ 296.40 & 2.24 & 1.37 \\ 296.88 & 2.38 & 1.14 \\ 296.88 & 2.34 & 1.11 \\ 299.00 & 2.42 & 1.21 \\ 299.50 & 2.50 & 1.26 \\ 299.50 & 2.27 & 1.11 \\ 300.00 & 2.40 & 1.07 \\ 300.50 & 2.10 & 0.82 \\ 300.50 & 2.29 & 0.84 \\ 301.00 & 2.15 & 0.88 \\ 301.50 & 1.98 & 1.01 \\ 302.00 & 2.44 & 1.14 \\ 302.50 & 2.28 & 1.24 \\ 303.00 & 2.41 & 1.07 \\ 303.50 & 2.35 & 1.03 \\ 304.00 & 2.25 & 1.28 \\ 304.50 & 2.41 & 1.16 \\ 305.00 & 2.21 & 1.21 \\ 305.00 & 2.36 & 1.08 \\ 305.50 & 2.20 & 1.30 \\ 306.00 & 2.26 & 1.26 \\ 307.00 & 2.26 & 1.37 \\ & & \\ \text { G. bulloides } & \end{array}$

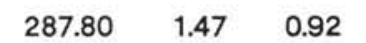

\begin{tabular}{llllll}
\multicolumn{2}{c}{ P. wuellerstorfi } & & 301.00 & 2.15 & 0.88 \\
279.30 & 2.15 & 0.98 & 301.50 & 1.98 & 1.01 \\
279.50 & 2.09 & 1.22 & 302.00 & 2.44 & 1.14 \\
279.80 & 2.32 & 0.99 & 302.50 & 2.28 & 1.24 \\
280.00 & 2.18 & 1.14 & 303.00 & 2.41 & 1.07 \\
280.30 & 2.38 & 1.12 & 303.50 & 2.35 & 1.03 \\
280.50 & 2.30 & 1.39 & 304.00 & 2.25 & 1.28 \\
281.00 & 1.98 & 1.32 & 304.50 & 2.41 & 1.16 \\
281.50 & 2.04 & 1.30 & 305.00 & 2.21 & 1.21 \\
281.80 & 2.47 & 1.34 & 305.00 & 2.36 & 1.08 \\
282.00 & 2.19 & 1.11 & 305.50 & 2.20 & 1.30 \\
282.30 & 2.50 & 1.43 & 306.00 & 2.26 & 1.26 \\
282.50 & 2.23 & 1.39 & 307.00 & 2.26 & 1.37 \\
282.80 & 2.10 & 1.04 & \multicolumn{3}{c}{ G. bulloides }
\end{tabular}

$\begin{array}{llllll}279.30 & 0.75 & 1.06 & 296.40 & 0.98 & 0.80 \\ 279.50 & 1.13 & 1.37 & 296.88 & 1.33 & 0.38 \\ 279.80 & 1.30 & 0.61 & 299.00 & 1.05 & 0.64 \\ 280.00 & 1.28 & 1.21 & 299.50 & 0.91 & 0.37 \\ 280.30 & 1.06 & 1.21 & 300.00 & 1.18 & 0.52 \\ 280.50 & 1.15 & 1.41 & 300.50 & 1.11 & 0.20 \\ 280.80 & 1.02 & 1.05 & 301.00 & 1.02 & 0.29 \\ 281.00 & 1.03 & 1.03 & 301.50 & 0.87 & 0.53 \\ 281.30 & 0.74 & 1.29 & 302.00 & 0.93 & 0.69 \\ 281.50 & 1.39 & 1.18 & 302.50 & 1.08 & 0.64 \\ 281.80 & 1.18 & 0.82 & 302.50 & 1.11 & 0.43 \\ 282.00 & 1.53 & 1.20 & 303.00 & 1.18 & 0.59 \\ 282.30 & 1.27 & 1.02 & 303.00 & 1.18 & 0.68 \\ 282.50 & 1.29 & 1.28 & 303.50 & 1.30 & 0.58 \\ 282.80 & 0.74 & 1.34 & 303.50 & 1.30 & 0.41 \\ 283.00 & 1.22 & 1.39 & 304.00 & 1.17 & 0.60 \\ 283.30 & 1.08 & 0.89 & 304.50 & 1.18 & 0.70 \\ 283.50 & 1.35 & 1.08 & 305.00 & 1.14 & 0.62 \\ 283.80 & 1.23 & 0.65 & 305.50 & 1.08 & 0.53 \\ 285.30 & 1.29 & 1.28 & 306.00 & 1.42 & 0.84 \\ 285.78 & 1.64 & 1.24 & 306.50 & 1.62 & 0.94 \\ 286.30 & 1.30 & 1.18 & 307.00 & 0.93 & 0.97\end{array}$

Hole $611 \mathrm{C}$

$\begin{array}{lll}287.00 & 0.59 & 1.39\end{array}$

$\begin{array}{lll}287.28 & 1.36 & 0.96\end{array}$

$\begin{array}{lll}287.28 & 0.96 & 0.54\end{array}$

$\begin{array}{lll}287.50 & 0.79 & 1.16\end{array}$

P. wuellerstorfi

$\begin{array}{lll}291.00 & 2.06 & 0.86\end{array}$ $\begin{array}{lll}293.02 & 2.06 & 0.66\end{array}$ 
Appendix (continued).

\begin{tabular}{|c|c|c|c|c|c|}
\hline $\begin{array}{c}\text { Sample } \\
\text { depth }(m)\end{array}$ & $\delta^{18} \mathrm{O}$ & $\delta^{13} \mathrm{C}$ & $\begin{array}{c}\text { Sample } \\
\text { depth (m) }\end{array}$ & $\delta^{18} \mathrm{O}$ & $\delta^{13} \mathrm{C}$ \\
\hline \multicolumn{6}{|c|}{ Hole 611C (Cont.) } \\
\hline \multicolumn{6}{|c|}{ P. wuellerstorfi (Cont.) } \\
\hline 293.02 & 2.04 & 0.97 & 375.80 & 1.11 & 1.09 \\
\hline 299.02 & 2.02 & 1.04 & 379.97 & 1.16 & 1.06 \\
\hline 300.30 & 2.13 & 0.87 & 381.94 & 1.19 & 1.00 \\
\hline 311.20 & 1.87 & 1.05 & 383.90 & 1.10 & 1.34 \\
\hline 312.20 & 1.88 & 1.09 & 384.91 & 1.10 & 1.20 \\
\hline 313.20 & 1.94 & 0.61 & 390.54 & 1.37 & 1.45 \\
\hline 321.96 & 1.47 & 1.00 & 391.57 & 1.05 & 1.40 \\
\hline 322.80 & 1.16 & 0.83 & 393.52 & 0.85 & 1.11 \\
\hline 323.80 & 2.10 & 0.67 & & & \\
\hline 326.80 & 1.77 & 0.78 & \multirow{2}{*}{\multicolumn{3}{|c|}{ G. bulloides }} \\
\hline 327.83 & 1.84 & 1.02 & & & \\
\hline 328.42 & 1.16 & 1.22 & 293.02 & -0.30 & -0.69 \\
\hline 328.80 & 1.71 & 0.88 & 295.00 & 0.15 & -0.07 \\
\hline 329.90 & 1.74 & 0.81 & 297.00 & -0.11 & -0.38 \\
\hline 330.90 & 1.54 & 0.72 & 299.02 & 0.27 & -0.58 \\
\hline 333.90 & 1.89 & 1.08 & 327.83 & 0.21 & -0.15 \\
\hline 339.02 & 1.39 & 0.73 & 328.80 & -0.29 & -0.41 \\
\hline 339.98 & 1.48 & 1.01 & 329.90 & 0.23 & -0.21 \\
\hline 341.00 & 1.71 & 0.95 & 330.90 & -0.44 & -0.59 \\
\hline 341.95 & 1.76 & 0.91 & 331.90 & -0.06 & -0.49 \\
\hline 343.00 & 1.23 & 0.96 & 341.95 & 0.06 & 0.03 \\
\hline 343.99 & 1.43 & 1.04 & 350.10 & -0.84 & -0.70 \\
\hline 345.00 & 1.57 & 1.00 & 373.84 & 0.66 & 0.89 \\
\hline 346.00 & 1.83 & 0.93 & 376.82 & 0.15 & 0.91 \\
\hline 346.99 & 1.22 & 0.80 & 381.94 & -0.14 & 0.60 \\
\hline 348.00 & 1.35 & 0.97 & 383.90 & -0.20 & 0.41 \\
\hline 349.14 & 1.71 & 0.87 & 385.90 & -1.09 & -0.11 \\
\hline 350.10 & 1.71 & 0.97 & 390.54 & -0.17 & 0.23 \\
\hline 351.10 & 1.44 & 0.70 & 391.57 & -0.32 & 0.12 \\
\hline 352.10 & 1.61 & 1.15 & 392.50 & -0.85 & 0.03 \\
\hline 368.75 & 1.68 & 1.30 & 394.50 & 0.17 & 0.29 \\
\hline 372.79 & 1.21 & 1.16 & 395.49 & -0.31 & -0.06 \\
\hline
\end{tabular}

